University of Rhode Island

DigitalCommons@URI

Open Access Master's Theses

1998

\title{
LAND USE SUITABILITY ANALYSIS: AN ASSESSMENT FOR THE RHODE ISLAND CENTRAL LANDFILL
}

R. William B. MacDaniel

University of Rhode Island

Follow this and additional works at: https://digitalcommons.uri.edu/theses

\section{Recommended Citation}

MacDaniel, R. William B., "LAND USE SUITABILITY ANALYSIS: AN ASSESSMENT FOR THE RHODE ISLAND CENTRAL LANDFILL" (1998). Open Access Master's Theses. Paper 515.

https://digitalcommons.uri.edu/theses/515

This Thesis is brought to you for free and open access by DigitalCommons@URI. It has been accepted for inclusion in Open Access Master's Theses by an authorized administrator of DigitalCommons@URI. For more information, please contact digitalcommons-group@uri.edu. 


\section{LAND USE SUITABILITY ANALYSIS:}

AN ASSESSMENT FOR

THE RHODE ISLAND CENTRAL LANDFILL

\section{BY}

R. WILLIAM B. MACDANIEL

A RESEARCH PROJECT SUBMITTED IN PARTIAL FULFILLMENT OF THE REQUIREMENTS FOR THE DEGREE OF

MASTER OF COMMUNITY PLANNING 
MASTER OF COMMUNITY PLANNING

RESEARCH PROJECT

OF

R. WILLIAM B. MACDANIEL

Approved:
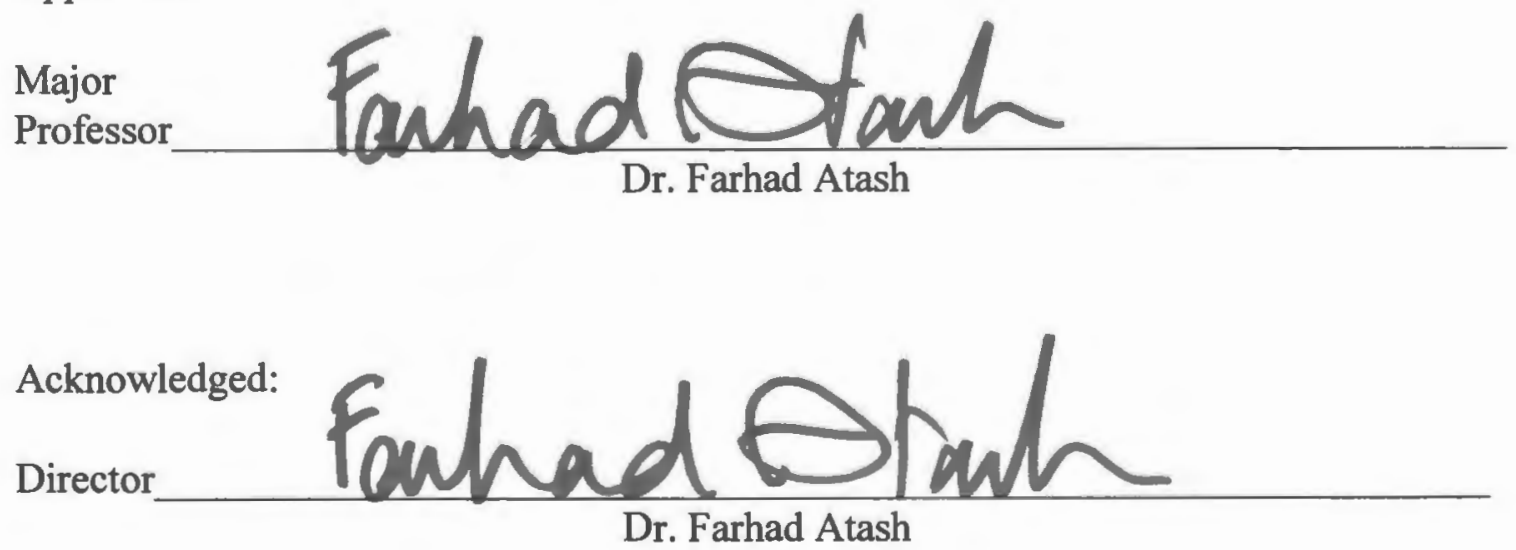


\begin{abstract}
The purpose of this research project was to develop an alternative methodology for the Land Use Suitability Study for the Rhode Island Central Landfill in Johnston, Rhode Island. The alternative methodology involved developing a means to analyze the Central Landfill property that is more in depth than the initial basic overlay analysis used in the 1996 Central Landfill Land Use Suitability Study. The means to accomplish this began with the a comparison of this study with other land use studies, and literature related to land use suitability studies. Particular attention was paid to methods of analysis. The intent was to identify topics of analysis omitted in the existing study, and weaknesses with the original methodology used to assign suitability for development values. A major intention of this research project was to improve the Central Landfill Land Use Suitability Study that was conducted by the author in the summer of 1996. Any improvements would enhance its value as an integral element of a comprehensive land use plan for the Rhode Island Central Landfill. The establishment of such a master plan would in turn function as a tool to guiding future land use decisions at the Central Landfill.
\end{abstract}




\section{ACKNOWLEDGEMENTS}

I would like to thank the readers of my thesis: Dr. Farhad Atash, Dr. Rolf Pendall, and Mr. Dante Ionata. I appreciate their time and assistance in guiding me through the process of producing this project. I would especially like to thank my parents for the support and encouragment of my parents through my years in the forest.

In particular I dedicate this project in my Mother's memory. 
PROJECT PURPOSE

DESCRIPTION OF STUDY AREA

SIGNIFICANCE OF THE STUDY

DESCRIPTION OF LITERATURE REVIEW

OBJECTIVES

PROCEDURES AND METHODS OF ANALYSIS

FACTORS USED IN LAND USE PLANNING AND LAND USE SUITABILITY ANALYSIS 5 CRITIQUES OF OVERLAY METHYODS AND WEIGHTING SYSTEMS THE ROLE OF GIS IN LAND USE PLANNING SUMMARY 
SIEVE SYSTEM OF LAND USE ANALYSIS

\begin{tabular}{lr} 
PROCESS & 22 \\
\hline SUMMARY
\end{tabular}

$\begin{array}{lr}\text { SUMMARY } & 23\end{array}$

CHAPTER FOUR: 1996 LAND USE SUITABILITY STUDY 24

$\begin{array}{lr}\text { INTRODUCTION } & 24\end{array}$

HISTORY OF CENTRAL LANDFILL $\quad 24$

$\begin{array}{ll}\text { GENERAL DESCRIPTION OF PROPERTY } & 24\end{array}$

$\begin{array}{ll}\text { PURPOSE OF LAND USE PLAN } & 25\end{array}$

SECTION 1. DESCRIPTION OF PROPERTY AND LAND USE 25

$\begin{array}{ll}\text { GENERAL INFORMATION } & 25\end{array}$

$\begin{array}{ll}\text { DESCRIPTION OF STUDY ZONES } & 27\end{array}$

$\begin{array}{lr}\text { SECTION 2. SOILS AND GEOLOGY } & 37\end{array}$

$\begin{array}{ll}\text { GENERAL INFORMATION } & 37\end{array}$

DESCRIPTION OF SOILS AND GEOLOGY IN STUDY ZONES

SECTION 3. WETLANDS AND SURFACE WATER 44

GENERAL INFORMATION $\quad 44$

$\begin{array}{ll}\text { WETLANDS } & 45\end{array}$

STERAMS $\quad 45$

DRAINAGE CHANNELS $\quad 47$

PONDS $\quad 47$

$\begin{array}{ll}\text { LAKES } & 47\end{array}$

DESCRIPTION OF WETLANDS IN STUDY ZONES

SECTION 4. LANDCOVER $\quad 49$

GENERAL INFORMATION $\quad 49$

$\begin{array}{lr}\text { SIZE GROUPS } & 50\end{array}$

$\begin{array}{ll}\text { LAND COVER TYPES } & 50\end{array}$

DESCRIPTION OF LANDCOVER IN STUDY ZONES

SECTION 5. ZONING AND STRUCTURES

GENERAL INFORMATION $\quad 55$

DESCRIPTION OF ZONING DISTRICTS $\quad 55$

$\begin{array}{ll}\text { STRUCTURES IN STUDY ZONES } & 57\end{array}$

SECTION 6. CONSTRAINTS AND OPPORTUNITIES $\quad 59$

GENERAL INFORMATION $\quad 59$

ENVIRONMENTAL AND PHYSICAL CONSTRAINTS $\quad 59$

LAND USE CONSTRAINTS $\quad 60$

$\begin{array}{lr}\text { LEGAL CONSTRAINTS } & 62\end{array}$

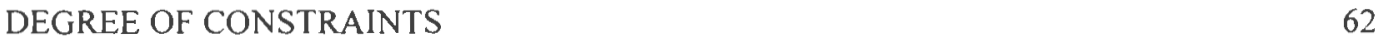

DESCRIPTION OF ZONE CONSTRAINTS $\quad 62$

LAND SUITABLE FOR DEVELOPMENT $\quad 66$

$\begin{array}{ll}\text { SUMMARY } & 67\end{array}$

CHAPTER FIVE: 1997 LAND USE SUITABILITY STUDY 70

ANALYSIS

SIEVE I ANALYSIS $\quad 70$

SIEVE 2 ANALYSIS

PRELIMINARY SUITABILITY ANALYSIS $\quad 72$

SIEVE 3 ANALYSIS $\quad 72$

SIEVE 4 ANALYSIS $\quad 75$

SIEVE 5 ANALYSIS $\quad 78$ 
TABLE 2.1 HIERARCHY OF URBAN SUIT ABILITY 6

TABLE 2.2 PLAN PREPARATION TECHNIQUES

TABLE 2.3 LAND USE VALUES

TABLE 2.4 FOUR FUNCTIONS OF A LAND USE PLANNING PROGRAM 8

TABLE 2.5 DATA FOR PARCELS

TABLE 2.6 LAND PLANNING AND DEVELOPMENT FACTORS 9

TABLE 3.1 LAND USE SUITABILITY MAPS

TABLE 3.2 SUITABILITY STUDY FACTORS, ATTRIBUTES AND CONSTRAINT LEVELS 18

TABLE 4.1 GROUP A SOIL DESCRIPTION

TABLE 4.2 GROUP B SOIL DESCRIPTION

TABLE 4.3 GROUP C SOIL DESCRIPTION

TABLE 4.4 GROUP D SOIL DESCRIPTION

TABLE 4.5 TREE SIZE GROUPS

TABLE 4.6 ZONING WITHIN AND ADJACENT TO STUDY ZONES

TABLE 4.7 ZONE 1 LOTS WITH STRUCTURES

TABLE 4.8 ZONE 3 LOTS WITH STRUCTURES

TABLE 4.9 ZONE 5 LOTS WITH STRUCTURES

TABLE 4.10 ZONE 6 LOTS WITH STRUCTURES

TABLE 4.11 STUDY FACTORS AND CONSTRAINTS

TABLE 4.12 LAND AREA PER CONSTRAINT LEVEL PER STUDY ZONE

TABLE 5.1 SIEVE 1 SCREEING RESULTS

TABLE 5.2 SIEVE 2 SCREEING RESULTS

TABLE 5.3 PRELIMINARY SUITABILITY ANALYSIS

TABLE 5.4A SIEVE 3 INDUSTRIAL USE SUMMARY

TABLE 5.4B SIEVE 3 INSTITUTIONAL USE SUMMARY

TABLE 5.4C SIEVE 3 COMMERCIAL USE SUMMARY

TABLE 5.4D SIEVE 3 RESIDENTIAL USE SUMMARY, LESS THAN 5 UNITS PER ACRE 74

TABLE 5.4E SIEVE 3 RESIDENTIAL USE SUMMARY, 5-10 UNITS PER ACRE

TABLE 5.4F SIEVE 3 RESIDENTIAL USE SUMMARY, 10 UN1TS OR MORE PER ACRE 75

TABLE 5.5A SIEVE 3 INDUSTRIAL USE SUMMARY

TABLE 5.5B SIEVE 3 INSTITUTIONAL USE SUMMARY

TABLE 5.5C SIEVE 3 COMMERCIAL USE SUMMARY 76

TABLE 5.5D SIEVE 3 RESIDENTIAL USE SUMMARY, LESS THAN 5 UNITS PER ACRE 77

TABLE 5.5E SIEVE 3 RESIDENTIAL USE SUMMARY, 5-10 UNITS PER ACRE

TABLE 5.5F SIEVE 3 RESIDENTIAL USE SUMMARY, 10 UNITS OR MORE PER ACRE 77

TABLE 5.6A SIEVE 3 INDUSTRIAL USE SUMMARY

TABLE 5.6B SIEVE 3 INSTITUTIONAL USE SUMMARY

TABLE 5.6C SIEVE 3 COMMERCIAL USE SUMMARY

TABLE 5.6D SIEVE 3 RESIDENTIAL USE SUMMARY, LESS THAN 5 UNITS PER ACRE 79

TABLE 5.6E SIEVE 3 RESIDENTIAL USE SUMMARY, 5-10 UNITS PER ACRE

TABLE 5.6F SIEVE 3 RESIDENTIAL USE SUMMARY, 10 UNITS OR MORE PER ACRE 80 


\section{LIST OF MAPS}

MAP 4.1 STUDY ZONES

MAP 4.2 SOIL CONSTRAINTS

MAP 4.3 SURFACE WATER AND WETLANDS

MAP 4.4 LANDCOVER

MAP 4.5 TOWN OF JOHNSTON ZONING

MAP 4.6 AREA LAND USE

MAP 4.7 DEVELOPMENT SUITABILITY 


\section{Chapter One \\ Introduction}

\section{Project Purpose}

The purpose of this research project is to develop an alternative methodology for the Land Use Suitability Study for the Rhode Island Central Landfill in Johnston, Rhode Island. The alternative methodology involved developing a means to analyze the Central Landfill property that is more in depth than the initial basic overlay analysis used in the 1996 Central Landfill Land Use Suitability Study. The means to accomplish this began with the a comparison of this study with other land use studies, and literature related to land use suitability studies. Particular attention was paid to methods of analysis. An intent was to identify topics of analysis omitted in the existing study, and weaknesses with the original methodology used to assign suitability for development values. A major intention of this research project was to improve the Central Landfill Land Use Suitability Study that was conducted by the author in the summer of 1996. Any improvements would enhance its value as an integral element of a comprehensive land use plan for the Rhode Island Central Landfill. The establishment of such a master plan would in turn function as a tool to guide future land use decisions at the Central Landfill.

\section{Description of the Study Area}

The Rhode Island Resource Recovery Corporation (RIRRC) currently owns 1,009 acres in Johnstown, Rhode Island. This property is the site of the State Central Landfill, and a material recycling facility. These two facilities are the major components of the Rhode Island waste management strategy. Based on 1996 rates of use, the anticipated life-span of the landfill facility is estimated at approximately 20 to 25 years, contingent upon the success of aggressive recycling operations. The property is surrounded by industrially zoned property along the south boundary; residentially zoned property to the east, north and west. A large part of the residentially zoned property has been developed, with new development occurring north of the facility spreading westward. The property consists of wetlands, dry uplands and terraces throughout the property. A significant portion of the property to the west of the Central Landfill is classified as wetlands.

\section{Significance of the Study}

The primary reason for the Land Use Suitability Study is to identify parcels of land owned by the RIRRC suitable for development. The development of parcels not necessary for landfill and recycling operations would add revenue-generating property to the Johnston tax base. An additional concern is to identify parcels suitable for future Town facilities such as a Town maintenance garage. Another concern not directly stated is the long-term use of the Central Landfill after its life as a landfill facility. The land use 
suitability study lays the basis for a comprehensive plan to manage RIRRC's property on a long-term basis that includes post landfill uses. An analysis identifying weaknesses, omitted topics of analysis, and potential land uses will aid in strengthening the study. The intent of this analysis is three-fold: 1) to provide a superior method of land suitability analysis, 2) to guide the development of the Land Use Plan, and 3) to expand the identified land use options. The ultimate goal is providing a guide to make informed land use decisions at the Central Landfill. Decisions that benefit the environment, the residents of Johnston, and the state by generating revenues, and minimizing conflict over land use decisions at the Central Landfill

\section{Description of Literature Review}

The literature used in this project falls within two categories. The first is the literature used in the initial land use suitability study, and the second is literature used to enhance the land use suitability study.

Literature used for initial landuse study.

Literature used for background regarding values, functions, characteristics of land and habitat types, and the relationships between land uses were: Classification of Wetland and Deepwater Habitats of the United States (Cowardin, 1979), Rhode Island Wetlands Inventory (Tiner, 1989), Soils Survey of Rhode Island (1977), Urban Land Use Planning (Kaiser, et al., 1995), Landscape Planning: Environmental Applications (Marsh, 1993).

Information specific to the Central Landfill property and operational plans was gathered from the Final Feasibility Study: Operable Unit OUI Central Landfill Volume I (1993) which includes a description of the sites history and physical characteristics, the Central Landfill Ecological Characterization Operable Unit 2 Remedial Investigation - Task 2 (1994)which describes the different plant communities and wetlands, and the Rhode island Comprehensive Solid Waste Management Plan (1996) that includes projections on landfill life expectancy and expansions.

Information regarding RIRRC's legal obligations and breadth of action are covered in the Rhode Island General Laws, and in RIDEM Rules and Regulations for Solid Waste Management Facilities. Information regarding the Town of Johnston's plans and ordinances was gathered from the Town's Zoning Ordinance, and sections of the draft Comprehensive Plan.

Preliminary List of Literature for the Enhancements of the Land Use Suitability Study,

Literature chosen with the intention to provide the background for the analysis of the basic methodology used includes Design with Nature (McHarg, 1967), Urban Land Use Planning (Kaiser, et al., 1995), and 
Landscape Planning: Environmental Applications (Marsh, 1993). The comparison of weighting systems from Methods for Generating Land Suitability: A Comparative Evaluation (Hopkins, 1977) is intended as a means of analyzing the method of weighting used in the Land Use Suitability Study. Two initial sources used in evaluating additional areas of study for the development of the Land Use Plan include the Comprehensive Reuse Plan Dovisville Naval Construction Battalion Center (Maguire Group, 1994), and

Industrial Site Survey, Westerly, Rhode Island (Quattromani, 1993). The Public Real Estate Development Process (Dowall, 1990) is included to develop an understanding of the public/private real estate development process that aids in developing a land use plan that enhances the benefits to the RIRRC as a public property owner.

\section{Objectives}

There are three primary objectives involved in the Central Landfill Land Use Suitability Study.

1. Identify an appropriate method of land use suitability analysis to improve the Central Landfill Land Use Suitability Study.

2. Identify appropriate format, areas of analysis, and implementation strategies used in land use plans to provide a framework for a comprehensive Central Landfill Land Use Plan.

3. Identify land uses that may be suitable for the RIRRC property at the Central Landfill.

\section{Procedures and Methods of Analysis}

1. Identify an appropriate method of land use suitability analysis to improve the Central Landfill Land Use Suitability Study.

a. List and compare the topics used in land use suitability methods, suitability studies, and land use plans.

b. Identify or modify methods appropriate to the Central Landfill study.

c. Identify an appropriate method of weighting the land use suitability variables and apply it to the Central Landfill study.

d. Reevaluate the land use suitability conclusions based on any modifications from the original method used in the Central Landfill Study.

2. Identify appropriate format, areas of analysis, and implementation strategies used in land use plans to provide a framework for a comprehensive Central Landfill Land Use Plan.

a. Compare the topics used in land use plans.

b. Identify sections of land use plans appropriate for use in a comprehensive land use plan for the central landfill. 
3. Identify land uses that may be suitable for the RIRRC property at the Central Landfill.

a. Using the land use suitability analysis identify the areas most suitable for various intensities of development.

b. Identify a range of land uses suitable for each study zone. 


\section{Chapter Two Literature Review}

This chapter reviews the literature used for this study. The review is divided into four sections. The first section discusses the literature related to the development of factors and values used in land use suitability analysis. The second section reviews critiques of overlay method and weighting systems. Section three reviews literature related to the use of Geographic Information Systems in land use planning. The last section includes a summary and critique of literature related to land use planning and specifically related to the Central Landfill Land Suitability Study.

\section{Factors used in Land Use Planning and Land Use Suitability Analysis}

This section discusses two studies as pertinent to land use suitability analysis and the land use planning process. The first of these, Design with Nature (McHarg, 1969), helped establish the basic elements and concepts of overlay analysis. The second, Urban Land Use Planning (Kaiser et. al., 1995), proposes a land development management system. The land development management system integrates overlay analysis as an important element of the management system. The basic idea of overlaying physical attributes in an "overlay analysis" has changed little since the publication of Design with Nature. The increasing sophistication of computers and software assisted the evolution from manual mapping and analysis to computer aided mapping and analysis.

Significant advances in overlay methods involve using Geographic Information System (GIS) technology. GIS technology helps solving scale problems related to using multiple scales by integrating various data sources into one data base. More powerful computers and software allow planners to make faster, and more complex calculations. GIS also aids the development of databases of land factors and attributes. McHarg's discussion of values, benefits, costs and savings of highway alignment (pp. 32-41), identifies several factors that apply to virtually any type of development. The primary factors and values identified include: slope, surface drainage, soil drainage, bedrock foundation, soil foundation, susceptibility to erosion, tidal inundation, historic, land, scenic, recreation, water, forest, wildlife, residential, and institutional values. These factors and values are analyzed according to the level of constraints placed on development.

In his discussion on "Nature in the Metropolis" (pp. 55-65), McHarg selects eight dominant aspects of natural process and rank(s) them in an order of natural process value (intolerance to human use), and then ranks these factors in a reverse order according to suitability for human use (Table 2.1). This ranking establishes a simple gross hierarchy of urban suitability in which the land types most suitable for human use tolerate human (ab)use best (McHarg, 1969:57). 
Table 2.1 Hierarchy of Urban Suitability

\begin{tabular}{ll}
\hline Natural-process V'alue: & $\begin{array}{l}\text { Intrinsic Suitability } \\
\text { Degree of Intolerance }\end{array}$ \\
\hline Surface water & Flat land \\
Marshes & Forests. woodlands \\
Floodplains & Steep slopes \\
Aquifer recharge areas & Aquifer recharge areas \\
Steep slopes & Floodplains \\
Forests. woodlands & Marshes \\
Flat land & Surface water \\
\hline Source. McHary. Design with W'uture. p 57 &
\end{tabular}

McHarg identifies conflicts within such a hierarchy. Often land forms that are most suitable for urban development are areas of high resource value. An example of this conflict is the conflict between residential and agricultural uses for level land. This conflict necessitates value judgments regarding greater public value. McHarg contends that, "a complete (suitability) study would involve identifying natural processes that performed work for man, those that offered protection or were hostile, those which were unique or especially precious and those values which were vulnerable" (p. 57). This illuminates the importance of developing a method that stresses the importance, and differences between natural and human values.

In the "Processes as values" (pp. 103-115) section, in a Staten Island study McHarg analyzed eight general categories with 32 natural and human related factors. The general factors were categorized according to climate, geology, physiography, hydrology, pedology, vegetation, wildlife, and land use. The attributes of these factors used ranking criteria based on a phenomenon's value for land use. The study analyzed land for conservation, passive recreation, active recreation, residential development, and commercial/industrial development uses.

Urban Land Use Planning (Kaiser et. al., 1995) expands on Design with Nature by proposing an entire land use development planning process that includes "overlay analysis" as one of its tools. The authors propose a system to integrate competing social, market and ecological values to manage land use change in a more sustainable manner. The basic element in developing their management process requires establishing a database that integrates physical, environmental, demographic, social, and regulatory factors on the community or regional scale. The development of such a land data base enables regular updating of conditions and ownership changes.

Kaiser et. al. support rational planning as the most appropriate basis for land use planning. They recognize that the shortcomings of a method lies within the realm of rational planning, and incorporate normative and descriptive theories of land use planning. Kaiser et. al. include "rational" and "adaptive" techniques in defining their system of land use planning and management. Table 2.2 provides a list of rational and adaptive techniques as suitable for inclusion in land use plans. This intends to make land use planning 
more responsive to social, economic, political and natural conditions. Computer and software technology offer the potential to provide the necessary link to move overlay analysis from being primarily an analytical tool to an important land management tool .

Table 2.2 Plan Preparation Techniques

\begin{tabular}{ll}
\hline Rational Techniques & Adaptive techniques \\
\hline Data analysis & Public participation and disclosure \\
Trend projection & Consensus building and conflict resolution \\
Supply and demand derivation & Monitoring and problem fixing \\
System modeling & Impact analysis and mitigation \\
Goal and objective statements & Capital budgeting and project review \\
Plan design & Plan evaluation \\
\hline Source: Kaiser et al, ('rbun land I'se Plaming.p 39 &
\end{tabular}

In chapter two of Urban Land Use Planning Kaiser et. al. identify three basic values underlying land use planning and decision making. The three values are: social use value, which weights land use as a setting for living lives; market values, which weight land as a commodity; and ecological values, which weight natural systems more heavily (Table 2.3). These values are, "sometimes separate and competing, sometimes intermingling and supportive" (p. 43).

Table 2.3 Land Use Values

\begin{tabular}{|c|c|}
\hline Values & Elements of Value \\
\hline Social & $\begin{array}{l}\text { Urban form } \\
\text { Activity systems } \\
\text { Neighborhoods }\end{array}$ \\
\hline Market & $\begin{array}{l}\text { Highest and best use as determined by market mechanisms. often fails to meet social needs. } \\
\text { Market and planning relationship } \\
\text { - Correcting market failure } \\
\text { - } \quad \text { Redistribution of wealth and power } \\
\text { - Public-private partnership }\end{array}$ \\
\hline Ecological & $\begin{array}{l}\text { Three main conceptions } \\
\text { 1. Efficient use of natural resources for human benefit } \\
\text { - Economic asset. pollution as residual from production and consumption } \\
\text { - } \quad \text { benefit/cost analysis } \\
\text { 2. Environmental integrity } \\
\text { - Carrying capacity } \\
\text { - Land suitability } \\
\text { - Sustainable development } \\
\text { 3. Preservation of nature }\end{array}$ \\
\hline
\end{tabular}

Source Kaiser et al. L'rbun land l'se Planning.pp 61-6?

In order to integrate these land use values the authors propose a two-part system. The first involves a land use change management system that incorporates structural concerns of human ecology, and political economic theories through land use planning concepts. The second part involves a planning discourse that incorporates process concerns of game theory through participation and dispute resolution concepts. In the development of a land use planning program the authors identified four primary functions; intelligence, advance planning, problem solving, and development management (Table 2.4). 
Table 2.4 Four Functions of a Land Use Planning Program

\begin{tabular}{ll}
\hline Function & Elements of Function \\
\hline Intelligence & Building and maintaining an information system \\
& Analyzing and interpreting data \\
& Disseminating information \\
Fdvance planning & Formulating and adopting policy \\
& Formulating and adopting a development management system \\
Problem solving & Analyzing and solving unanticipated problems \\
& Assessing proposals to change development management system or develop land \\
Development management & Applying. enforcing. and improving ordinances. plans. capital improvement programs. \\
& acquisitions. information and other elements of the development management system.
\end{tabular}

Source Kaiser et al l'roum Lamd l'se Plaming pp $6 \mathrm{l}-6$ ?

Kaiser et. al. recognize the value of GIS in developing a land development management system. An advantage of GIS is that it improves the ease of establishing a system for analyzing and managing land development processes at scales ranging from large land holdings of a few hundred acres to multi-state regions. To make a system usable it should include two spatial data types. These are graphic identifiers, and tabular attribute data for a parcel of land. A GIS uses a variety of information including AutoCAD, GIS systems such as the Rhode Island GIS (RIGIS), aerial surveys, and ground surveys.

In Urban Land Use Planning the authors identify several factors for inclusion in land use analysis and planning. Many of the physical factors remain the same as identified by Ian McHarg in Design with Nature. Kaiser et. al, identify several sources of data suitable for developing a more extensive land parcel data file. They identify four categories of data for a parcel data file (Table 2.5).

Table 2.5 Data for Parcels

\begin{tabular}{|c|c|}
\hline Data Type & Elements and Factors of Data Type \\
\hline \multirow[t]{8}{*}{ Geographic identifiers } & Parcel identification number, usually based on a State plane coordinate system \\
\hline & Tax map. block, and parcel number \\
\hline & Site address \\
\hline & Census tract and block \\
\hline & Planning. school. electoral districts \\
\hline & Utility or service district \\
\hline & Traffic analysis zone \\
\hline & TIGER file identifier \\
\hline \multirow[t]{7}{*}{ Assessor's information } & Land use code \\
\hline & Size \\
\hline & Owner's name and address \\
\hline & Assessed value \\
\hline & Tax status and legal description \\
\hline & Recent sales price and date \\
\hline & Easements. deed restrictions. or permit conditions \\
\hline \multirow[t]{7}{*}{ Planning information } & General plan designation (proposed future land use and density) \\
\hline & Zoning classification \\
\hline & Existing land use type \\
\hline & Intensity of use \\
\hline & Infrastructure availability \\
\hline & Growth management status \\
\hline & Hazard area \\
\hline \multirow[t]{5}{*}{ Site characteristics } & Topography and slope \\
\hline & Soils and septic potential \\
\hline & Vegetation and land cover type \\
\hline & Watershed and aquifer recharge area \\
\hline & Proximity to road \\
\hline
\end{tabular}


The above types of data assist in enhancing the value of a land use management plan. In addition to the above data types, the authors discuss various social, market and environmental values and factors (Table 2.6).

Table 2.6 Land Planning and Development Factors

\begin{tabular}{|c|c|c|}
\hline General Values & Characteristics & Factors \\
\hline \multirow[t]{6}{*}{ Social/economic } & Population & Size \\
\hline & & Composition \\
\hline & & Distribution \\
\hline & Economy & Changes in local economy \\
\hline & & Types of employment \\
\hline & & Percentage of local population employed locally \\
\hline \multirow[t]{15}{*}{ Environmental } & Land & Soil \\
\hline & & Geology \\
\hline & & Topography \\
\hline & & Slope \\
\hline & & Land cover \\
\hline & & Vegetation \\
\hline & Water & Surface streams \\
\hline & & Surface lakes and ponds \\
\hline & & Floodplains \\
\hline & & Wetlands \\
\hline & & Water quality \\
\hline & Air quality & \\
\hline & Habitats & Distribution \\
\hline & & Character \\
\hline & Environmental Policy & Relevant regulations and permitting \\
\hline \multirow[t]{30}{*}{ Land use } & Parcel & Location \\
\hline & & Ownership \\
\hline & & Zoning \\
\hline & & Area \\
\hline & & Assessed value \\
\hline & Structure & Building type \\
\hline & & Ground coverage \\
\hline & & Number of floors \\
\hline & & Height \\
\hline & & Assessed value of improvements \\
\hline & & Floor area \\
\hline & & Condition \\
\hline & Space use & Existing uses \\
\hline & & Number of units \\
\hline & & Number of employees \\
\hline & & Intensity of use \\
\hline & & Number of residents \\
\hline & & Planned future use \\
\hline & Infrastructure & Water \\
\hline & & Sewer \\
\hline & & Electric \\
\hline & & Gas \\
\hline & & Telephone \\
\hline & & Transportation systems \\
\hline & Community facilities & Schools \\
\hline & & Recreation and Entertainment \\
\hline & & Health-care \\
\hline & & Police/fire protection \\
\hline & & Libraries \\
\hline & & Solid waste treatment \\
\hline
\end{tabular}

Note Compiled from ('rbun Land l'se I'lanming. chapters 5-9

Design with Nature and Urban Land Use Planning provide the basis for developing land use plans. The concepts and basic processes espoused by Ian McHarg establish basic techniques for doing overlay 
analysis. Granted, some of the assumptions made by McHarg regarding the suitability of land types for certain forms of development can not be applied with a broad brush. To do so without considering the unique context of each location would result in development in similar patterns. For example, across the board use of this system of analysis means we would never again build hill towns such as those of Tuscany because hillsides would be considered entirely unsuitable for development. The one-acre residential density for forested plateaus result in an inefficient use of land that play a role in the low density dispersal of population that is a major component of sprawl. Low density sprawl also destroys the rural character that one-acre zoning meant to preserve. Suitability analysis techniques have evolved since McHarg wrote Design with Nature. Whereas Design with Nature provides some of the basic tools necessary for developing a suitability analysis, Urban Land Use Planning provides tools to develop a land use plan. Again, it is important to identify the elements that are important for the individual study.

Not all data sources are available for each location. Parts of the data base unique to the location require the planner to develop an individualized data base. At what size of project does it become appropriate for a planner to develop a land management system? Is it an appropriate method for a site such as the Rhode Island Central Landfill? A planner must answer these questions on a project by project basis. An important element to the development of a land use plan is a quality comprehensive plan, and parcel data base on the part of the Town. Growth projections for that part of town are required. Planners need superior data to prepare adequate plans. In the case of the Central Landfill several of the elements required to develop a data base for RIRRC property is available, but Johnston's lack of a comprehensive plan and poorly organized parcel data base make a system envisioned by Kaiser et. al. unlikely. This requires open communication and work between the Town of Johnston and RIRRC to avoid a return to the past's rancorous relationship. Regardless of the extent that the land development management process can be implemented, Kaiser et. al. expand discussions about relationships between the elements of an integrated land use planning and development system. An awareness of the interrelationship between all of these elements results in a more effective land use planner.

\section{Critiques of Overlay Methods and Weighting Systems}

The critique in Methods for generating land suitability maps: A comparative evaluation (Hopkins, 1977) focuses on methods used for weighting various environmental factors. A major critique revolves around the means used to handle independence and interdependence between factors and attributes. Kaiser et. al. refer to some of the criticisms Hopkins discusses. Another major criticism discussed by both studies addresses the problem of weighting factors and attributes in a manner that reflects their importance in determining development. "The original procedure for land suitability analysis (McHarg, 1969) relied upon overlaying hand-drawn, transparent maps of which the intensity or importance of a particular factor was shown in various shades of gray, with the darkest gray representing the most intense or important 
degree of the factor. ... Critics of this technique questioned its assumptions about the validity of adding quantities measured in different units,..." (Kaiser et. al., 1995: 216).

Hopkins (1977) refers to this method as an "ordinal operation method." Essentially, this method simultaneously identifies homogenous regions and determines suitability ratings. This method involves four steps. The first step requires mapping each set of factors (e.g. soils, slope) and the distribution of types or attributes (soil types, slope classes). The second step consists of filling in a table that reflects the relative suitability rating for each land use type of each factor. The third step consists of making a suitability map for each land use based on each factor. The fourth step consists of overlaying for each land use, the suitability maps for each factor. The resulting composite map reflects the suitability for each land use. The resulting product is a series of maps that show the suitability patterns for each land use. Criticisms of this method are that it may inappropriately minimize more severe conditions; imply independence of factors (fails to relate interdependent factors); and it implies the addition of ordinal numbers (same weight for each factor).

Criticisms of the ordinal method influenced the development of different mathematical combination methods. Hopkins considers each of these methods either insufficient or invalid by itself. The first of these is the "linear combination method" that was a response to the weighting critique of the ordinal method. This method changes the unit of measure results in ratings by placing them all on the same interval scale. A criticism of this method is that even by developing an all inclusive rating system, the problem of handling interdependence between factors remains.

On the other hand there are "nonlinear combination methods" that do address the problem of interdependency between variables. A problem with this method relates to the large amounts of data required to develop a data base needed to know the precise relationships among the factors. This method results in limited operational usefulness, because the full range of costs and impacts are insufficient to determine the precise mathematical relationships.

The "factor combination method," used by McHarg in the "plan for the valleys," addresses interdependence among factors, but it functions at a loss in efficiency. A major difference from the "ordinal method" is the reversal of steps two and three. The second step involves combining type maps for each factor in order to develop a composite map of regions that are homogenous. The third step involves a derivation of the suitability rating's table. Rather than create a list of factors and types for each use, the identification and evaluation of mapped regions does not consider the relationships among individual factors. Hopkins considers the "factor combination method" appropriate for determining suitability for a limited number of factors. This method involves mapping homogeneous regions with a series of 
combinations and evaluations. Two criticisms concern the limited number of factors it can use, and rating suitability requires implicit value judgments.

In his methods evaluation, Hopkins identifies two combination methods as appropriate for determining land use suitability. The first of these is the "rules of combination method." The rules assign suitability to combinations of types rather than single combinations. The rules are expressed verbally rather than as numbers and precise mathematical formulas. The verbal rules result in a method more explicit than the "factor combination method", while addressing the problem of interdependence. There are five basic elements to the method. The first maps the factors. The second rates the types within the factors as in the "ordinal combination method." The third involves establishing the non-graphic general rules, such as the rating of the worst factor in a given region overriding the rating of all other factors (e.g. wetlands, or prime agricultural land overriding the suitability of level land for industrial development). The fourth involves identifying sets of combinations rated by the application of different rules such as the relationship between soil drainage, soil depth, depth to bedrock, slope, and vegetated slopes. The final element uses the verbally expressed rules to determine the composite ratings. This method requires an understanding of relationships within the natural system, rather than using a single set of relationships repeated for all combinations. The method does not force planners to address possible relationship on an individual basis. Carefully devised rules have the potential to address the problem of interdependence among factors.

The "hierarchical combination method" provides a more structured approach to combining interdependent factors into a composite rating. There are four basic elements in this method. The first element requires combining types from each subset of strongly interdependent factors which are rated as combinations. This permits consideration of interdependence among the factors in each subset. In the second higher order combinations are rated for suitability, with each lower order combination treated as an integrated whole. Third, the above sequence is repeated for all relevant factors. Fourth, combinations of types in a subset are evaluated once, rather than every time it appears. In situations where there are several factors resulting in a large number of combinations the hierarchical method may be too unwieldy to use efficiently.

Kaiser et. al. (1995) provides a model for determining land use suitability for specific uses. The method contains elements of the "factor combination model," and some elements of the "rules combination method." Primarily it sets up a system of analysis for each combination of factors related to each land use type. Combining factors take into consideration the variation's interdependency among factors in relation to different land uses without specifically identifying and rating each combination. The method involves eight steps. The first step selects the land use for analysis. Step two involves determining the site attributes that determine suitability for that use. The third step places the internal attributes of each factor in an 
internal ranking, based on its contribution to suitability. The fourth step involves weighting each individual attribute based on relative importance for the suitability of that use being analyzed. Step five is the combination of ranking scores and weights. This involves multiplying the ranking score by the weight attributed to each factor. The rules of combination define how weighted attributes (factors) combine into a single suitability rating. Rather than using verbal system of rules, Kaiser et. al. use a mathematical combination that can be addition, multiplication or an algorithm. The sixth step reclassifies the range of scores into composite suitability classes. The authors stress the need to ascertain the combinations of attributes in each class. Step seven calls for transforming the outcome into a suitability map. The final step involves the generation of a statistical report showing the results for each suitability class. The process is repeated for each land use.

The method proposed by Kaiser et. al. doesn't specifically address the issues of interdependency, and other factors outside the realm of mapping that impacts the suitability for a land use. Establishing rules of combination addresses these issues by removing unsuitable land areas out of the analysis for that land use. The method discussed by Kaiser et. al. returns to criticisms of McHarg regarding the use of disparate numerical scales, and problems with managing interdependency among factors. Their method relies heavily on determining mathematical relationships between factors on disparate scales. It requires more time, and expense to develop the suitability determination. This reduces its suitability in situations where time and budget considerations constrain the complexity of analysis. The rules combination method that Hopkins (1977) discusses should allow greater ease of use, managing interdependence, and less time. Additionally, the potential exists to provide greater flexibility in analyzing a variety of land uses for different conditions. The emphasis on verbally determined rules provides greater flexibility.

\section{The Role of GIS in Land Use Planning}

Literature over the last few years points to a major role for GIS in the land development process. The literature used focuses on the management of the physical side of the land development and management process. The literature ranges from using GIS to develop land use plans and developing data management systems that more effectively guide land development patterns. Kaiser et. al. stress the suitability of GIS software for managing the criticisms of overlay analysis and interdependency among factors by weighting factors prior to combination. GIS also handles the problem with multiple gray tones that are virtually indistinguishable by combining them into suitability classes based on a range of scores. Landis (1995) and Dueker et. al. (1990) find an appropriate use of GIS in the development of parcel inventories. Ultimately the development of such a system is possible for RIRRC. This parcel inventory could integrate physical, land use, legal, jurisdictional, and environmental data regarding parcels of land within entire property. Such a data system would enhance the development of an effective land use plan. A significant amount of relevant data exists with different institutions and data bases. These sources include various RIRRC 
records, Town of Johnston departments, and providers of public services. The major task involved requires collecting and inputting the data into an accessible database.

\section{Summary}

Focusing almost exclusively on environmental factors minimizes the interrelationship between development policies, environmental policies, social policies, regulatory policies, and factors that either influence or are influenced by development. For example. a policy that evolves almost exclusively on environmental factors without sufficient consideration of social and demographic factors may result in policies that negatively impact public health and affordable housing goals. Additionally the tendency to analyze the site out of regional context may result in negative local and regional impacts.

A critique from a landscape ecology point of view revolves around the idea that overlay analysis turns land parcels into discrete land units that are unique entities. This view may not consider the overall suitability of land for development on a regional basis. What is the concentration of contiguous parcels and connections by corridors? Failure to see the relationship between parcels results in scattered, inefficient development. It fragments wildlife habitat creating biotic islands of limited gene pools. This in turn not only reduces the viability of an endangered species, but reduces habitat required to support species such as songbirds. Eventually the decline in biotic diversity results in sterile patches of vegetation that are no longer communities.

When working on a project such as the land use plan for the Rhode Island Central Landfill, is it even necessary to develop a method of analysis as complex as those proposed by Kaiser et. al.? Are more complex combination even necessary? There is a fair amount of literature on using overlay analysis for determining suitability for large land areas with diverse land uses. Past studies focus on the development of plans to manage land at local and regional levels. What about sites with a few uses and the size of the Central Landfill? It is assumed for this study that a basic overlay analysis with well defined rules related to the site and its unique conditions provide adequate base for analysis. Additionally, well defined rules address infrastructure, political, public services, and legal/regulatory considerations. Well thought out rules offer the opportunity to address landscape ecology concerns by keeping the analysis in a more regional context.

It is important that planners rapidly identify all factors that impact land use, and are in turn impacted by land use decisions. Planners must recognize that not all factors have the potential for graphic depiction, nor is it possible to rank every possible factor on a numerical scale. Well thought out rules provide flexibility that responds to changing social, demographic, and political conditions in a way that a system of ranking does not. The method of establishing verbal rules integrates adaptive planning techniques that 
respond to criticisms of rational planning. This also addresses critiques questioning the validity of adding quantities measured in different units to arrive at one discrete suitability score. The "ordinal operation method" when combined with well conceived, detailed verbal rules regarding interdependency between factors reduces time and expense in developing a methodology suitable for a specific project. 


\section{Chapter Three \\ Methodology}

This chapter is divided into five sections. The first section provides an overview of factors and attributes used in literature and plans reviewed. The second section reviews factors used in the initial study. The third section discusses the methods and rules used to determine the initial development suitability. Section four identifies elements not included in the initial study that require inclusion in the suitability analysis or a Central Landfill Land Use Plan. Section five covers the methodology for enhancing the suitability analysis.

\section{Determination of Factors and Attributes}

Depending on the scope of a study, or a project's unique circumstances, the factors and attributes used in a land suitability analysis will vary. Additionally, the weighting method of these factors and attributes depend upon the comprehensiveness and nature of each study. Land use plans reviewed for this study tend toward greater comprehensiveness than more narrowly focused land use suitability studies. The larger a site or study area which is more integrated with the overall community tends to result in a more comprehensive plan. The better integrated plans look beyond the natural attributes to integrate nonphysical factors. Land use suitability studies play an important role in determining the environmental appropriateness for particular land use. Therefore, some factors may be less important to a suitability study than to a land use plan.

The first step for determining the appropriateness of certain factors and attributes for the initial Land Use Suitability Study required a review of background literature. The literature reviewed addressed environmental factors, past site studies, and legal descriptions of land use constraints. Literature used for the initial land use study established background information regarding the social, physical, and environmental values of physical factors such as wetlands. Values identified include environmental roles and characteristics of land habitat types; and the relationships between different land uses. The primary studies used include: L. Cowardin, Classification of Wetland and Deepwater Habitats of the United States (U.S. Fish and Wildlife Service, 1979); R. Tiner, Rhode Island Wetlands Inventory (U.S. Fish and Wildlife Service, 1989); Soils Survey of Rhode Island (United States Soil Conservation Service, 1977); E. Kaiser, et. al., Urban Land Use Planning (University of Illinois Press, 1995); W. Marsh, Landscape Planning: Environmental Applications (Wiley, 1993). Cowardin and Tiner helped to define the characteristics of different wetland types as they apply to the wetlands located on RIRRC property. Using the Rhode Island Wetlands Inventory in conjunction with the Soils Survey of Rhode Island described the wetland soils present on RIRRC property. Additionally, the Soils Survey of Rhode Island provided information regarding soil descriptions and suitability for different uses. The Urban Land Use Planning and 
Landscape Planning: Environmental Applications identified land characteristics for inclusion in land suitability studies.

Three sources of information specific to the Central Landfill property and operational plans added detail to the background environmental information. The Final Feasibility Study: Operable Unit OUI Central Landfill Volume I (GZA GeoEnvironmental, 1993) provided descriptions of the Central Landfill history and physical characteristics. The Central Landfill Ecological Characterization Operable unit 2 Remedial Investigation - Task 2 (GZA GeoEnvironmental, 1994) provided a large amount of the ecological information used in the initial study. The Rhode Island Comprehensive Solid Waste Management Plan (Rhode Island Resource Recovery Corporation, 1996) provided projections on the landfill life expectancy and the status of future expansions.

Rhode Island General Laws, Section 23-19-34 and Section 23-19-35 and the Rhode Island Department of Environmental Management Rules and Regulations for Solid Waste Management Facilities outline RIRRC's legal obligations and mission. Information regarding the Town of Johnston's incomplete comprehensive plan and ordinances required study of the Town's Zoning Ordinance and completed sections of the draft Comprehensive Plan.

The variety of data sources allowed identification of environmental, physical, land use, and legal factors affecting land use at the Central Landfill. Natural physical and environmental factors included: soils; surface and bedrock geology; wetlands; surface water; and land cover. Human factors included: current and future planned land use on and off site; on-site structures; and access. Legal and physical constraints included: zoning; wetland buffers; statutory landfill buffer requirements; and statutory land use restrictions placed on Central Landfill property within the 1000-foot and 2000 -foot buffers. The only major infrastructure element addressed was road accessibility because the Industrial Park Feasibility Study gathered that information.

\section{Mapping Factors}

Sources of data used for included: Rhode Island Geographic Information System (RIGIS); Rhode Island Resource Recovery Corporation (RIRRC) survey and detailed AutoCAD coverage. Zoning and parcel information for the Town of Johnston required verification at Town Hall. Information used to add detail to RIGIS coverage included the Central Landfill Ecological Characterization Operable unit 2 Remedial Investigation - Task 2 (1994). This information included wetlands delineation, land cover definitions, delineation of ecologically sensitive lands for the licensed operations area and surrounding sections of RIRRC property. Property not covered in that survey includes the area covered by the Industrial Park Feasibility study, the property north of Central Pike, and the most westerly sections of RIRRC property. 
The various factors mapped resulted in the development of eight maps covering various attributes, constraints and overall development suitability. Maps used for the final report are listed in Table 3.1.

Table 3.1 Land Use Suitability Maps

\begin{tabular}{ll}
\hline Map Number & Map Name \\
\hline 4.1 & Study Zones \\
4.2 & Soil Constraints \\
4.3 & Surface Water and Wetlands \\
4.4 & Landcover \\
4.5 & Town of Johnston Zoning \\
4.6 & Area Land Use \\
4.7 & Development Suitability \\
\hline
\end{tabular}

\section{Determining Development Suitability}

The initial study focused on the "overall" development suitability of all RIRRC property at the Central Landfill, rather than a discrete analysis for a series of land uses. Primary determinants for development suitability were the environmental, physical, regulatory, and legal constraints to land development (Table 3.2).

Table 3.2 Suitability Study Factors, Attributes and Constraint Level

\begin{tabular}{|c|c|c|}
\hline Factors & Attributes & Constraint Level \\
\hline \multirow[t]{3}{*}{ Slope } & Less than 8 per cent & Slight \\
\hline & 8 to 15 per cent & Moderate \\
\hline & Greater than 15 per cent & Severe \\
\hline \multirow[t]{4}{*}{ Soils and Water } & Wetlands/hydric soils & Severe \\
\hline & Seasonal High Water Table & Moderate to severe \\
\hline & Moderately drained soils & Moderate \\
\hline & Well drained soils & Slight \\
\hline \multirow[t]{2}{*}{ Bedrock geology } & Less than 6 feet deep & Moderate to severe \\
\hline & Greater than 6 feet in depth & Slight \\
\hline \multirow[t]{4}{*}{ Land cover } & Upland forest & Slight to moderate \\
\hline & Swamp/transitional forest & Moderate to severe \\
\hline & Marsh/shrub swamp & Severe \\
\hline & Upland Field & Slight \\
\hline \multirow[t]{4}{*}{ Legal restrictions/controls } & Wetland buffers & Severe \\
\hline & 600 foot landfill development buffer & Severe \\
\hline & 1000 foot development restriction & Severe \\
\hline & 2000 foot development restriction & Moderate \\
\hline Buildings and structures on RIRRC property & N/A & \\
\hline \multirow[t]{3}{*}{ Johnston Zoning } & Residential $(\mathrm{R}-40)$ & \\
\hline & Industrial & \\
\hline & Light industrial & \\
\hline
\end{tabular}

The overlaying of the above factors, land use, and soil suitability resulted in an initial suitability determination. This overlay process identified land polygons of different constraint levels. The attribute that most severely constrains development is used as the most limiting factor which provides the base level of development suitability. The constraints related to soil provided the most limiting factor, but the relationship between factors also played a role in the determination of suitability. For example, wetlands and hydric soils provided the most severe constraints to development. Yet, factors such as depth to bedrock, surface boulders, land cover and slope may relate in a manner that is unique to the site reducing the developability of a land parcel. Additionally, several non-mapped factors affect overall development 
suitability. Factors used to determine suitability include: degree of accessibility; size of suitable areas; degree of isolation from other suitable areas; depth of an area; proximity and degree of enclosure by wetlands; proximity to residential properties; and location within watershed protection areas.

The wide range of factors affecting the development suitability resulted in five constraint categories, rather than three. The first used was "slight", meaning that there are few factors limiting the overall developability of the land. The second was "slight to moderate" which includes additional constraints such as reduced access or slightly steeper topography. The third constraint was "moderate" which includes current, future, or adjacent land uses; and regulatory constraints. The fourth "moderate to severe" takes into consideration more restricted access that isolates developable land, specific future uses that preclude other uses. The fifth class, "severe", includes land that is essentially undevelopable. These areas include land designated for future landfill operations, wetlands, surface bedrock, or slopes in excess of fifteen percent.

Essentially, the land use suitability analysis inadvertently addresses some of the principles and processes discussed by Hopkins (1977) regarding "rules of combination method". The difference is that the study does not explicitly integrate elements of "factor combination method". The process used in the suitability study more closely resembles "ordinal combination method" reinforced by rules of combination. The difference is that for the study, combination rules were not explicitly stated. From this vantage point after reviewing the study and literature, ordinal combinations with explicitly stated rules regarding combination and priority factors are sufficient in analyzing land use suitability with the size and limited concerns that extend beyond the site.

\section{Elements that Require Inclusion}

A review of the Central Landfill Suitability study identified a list of elements, maps, and tables for inclusion in an enhanced suitability study. The completed Industrial Park Feasibility Study (Crossman Engineering, Inc., 1996) provides the missing infrastructure data. The introduction of the suitability study lacks an area context map. The study needs the inclusion of a table listing the attributes and constraints of the soil types present at the Central Landfill. Finally, rather than strictly providing an overall development suitability map, the enhanced analysis will address industrial/commercial, recreation/open space, housing (although not allowed by statute), and institutional uses.

\section{Methodology for Suitability Analysis}

The enhanced study uses the same sources as the initial study with the exception of infrastructure analysis which is provided by the Industrial Park Feasibility Study. The methodology essentially remains the same with two exceptions. The first exception is that three discrete land uses are analyzed rather one broad analysis. Second, the analysis requires explicitly determining rules of combination and factor priority. The 
three classes of land use analyzed combined industrial with institutional and commercial uses, residential use and open space. Industrial, commercial and institutional uses were combined because they display comparable environmental and physical needs, and impacts. The primary difference in impact relates to relative compatibility with residential use. With the exception of licensed landfill operations land not suitable for development provide opportunities to meet conservation, open space, and passive recreation needs. Even though residential uses are addressed even though such use is currently prohibited by the legislation which required RIRRC to purchase residential properties within 2000 feet of the licensed Central Landfill.

The method chosen for more discrete analysis uses elements of "rules of combination method" (Hopkins, 1977). The first requires mapping the factors. The second rates the types (attributes) within the factors as in the "ordinal combination method." The third involves establishing the non-graphic verbal rules, such as rating the most constraining factor in a given study zone. The most constraining factors overrides factors (i.e., wetlands, or prime agricultural land overriding the suitability of level land for industrial development). The fourth step involves identifying sets of combinations rated by the application of different rules. In the final element the verbally expressed rules determine the final composite ratings for each land use.

\section{Combination Rules}

A set of rules capable of minimizing the problems of interdependency, and factors in the unique attributes of a site is necessary to determine appropriate land uses. In order to achieve this need, three general categories of rules were developed. The three categories of constraints are: environmental and physical; infrastructure and access; and legal and regulatory constraints. Several of the rules state considerations and relationships used in the initial study.

\section{Environmental and Physical Constraints}

1. Wetland areas are not developable.

2. Areas within wetland buffers are not developable.

3. Slopes greater than fifteen per cent are not developable.

4. Areas with exposed surface bedrock are not developable.

5. Areas of human activity are developable except when within the licensed landfill area.

6. Slopes of eight to fifteen percent when combined with shallow bedrock or surface boulders make any well-drained soil undevelopable.

7. Upland forest on slopes of eight to fifteen percent are not developable.

8. Surface boulders reduce developability of well-drained soils and slopes less than eight percent. 
9. The area of land known as round rocks is not developable due to the concentration of boulders at the surface.

10. Land enclosed by wetlands on three sides are unsuitable unless the area is ten acres or larger with direct access to roads.

11. Land enclosed by wetlands on two sides are generally suitable for development.

12. Areas within watershed protection area are not suitable for development.

13. Areas of land isolated from other suitable parcels or by lack of road access are not developable.

Infrastructure and Access Constraints

1. Access through residential areas renders land unsuitable for industrial development.

2. Access through residential areas reduces the suitability of land for more intense commercial and institutional uses.

3. Areas adjacent to residential areas are unsuitable for industrial use.

4. Areas adjacent to residential areas are suitable for less intensive institutional, professional, or commercial use.

5. Lack of direct road access renders developable lands less suitable.

6. Isolated areas less than ten acres are unsuitable for development.

7. Areas without direct road access that are isolated by wetlands or other environmentally sensitive areas are rendered unsuitable for development.

8. Suitability of areas beyond 500 feet from water and sewer lines is reduced (for major development not as important).

9. Areas beyond 1000 feet from water and sewer lines are considered unsuitable for development (with the exception of the industrial park study area).

Legal and Regulatory Constraints

1. Land within the 600-foot DEM landfill development buffer is prohibited for development.

2. Land within 2000-foot development buffer is limited to industrial development (Sections 23-19-34, 35 R.I.G.L.).

\section{Sieve System of Land Use Analysis}

Even though the basic combination rules provide a basis to reduce problems associated with intradependency, in themselves the "rules of combination" do not provide a format to perform a land use analysis. What the rules do is guide the analysis process. In order to use the devised rules of combination a system of analysis was developed to gradually eliminate land unsuitable for development through the overall process, and in the later phases adjusts the overall suitability level to the specific land uses 
analyzed. The system devised is best compared with running soil through a series of sieves. Each sieve is comprised of progressively finer mesh suitable to screening out smaller and smaller soil particles.

\section{Process}

The first two sieves focus on eliminating unsuitable parcels from the analysis. Sieve One eliminates factors that individually are unsuitable for development. Factors used are primarily environmental and physical in nature. Also considered are current land uses, along with legal restrictions related to environmental protection. Factors used in the first sieve are hydric soil; slopes greater than 15 percent; surface bedrock; the "round rocks" an area of surface boulders on RIRRC property; area within legal wetland buffers; land within the Scituate Reservoir Watershed Protection District; land within the 600-foot DEM buffer around the licensed landfill; and, land used for landfill operations.

The second sieve eliminates parcels that are unsuitable for development based on a combination of environmental and physical factors. This level attempts to manage for the interdependncy between slope and other factors. The base attribute used is a slope of 8-15 percent. Two combinations are used in the second sieve level. The first combination is the slope combined with surface boulders. The second combines 8-15 percent slope, forest, and soil with a high erosion hazard. This sieve seeks to identify combinations of attributes that in themselves may not necessarily preclude development, but alter the degree of constraint unique to the combination of factors.

The next step in the process is a basic factorial analysis based on the five suitability levels: 1) slight; 2) slight to moderate; 3 ) moderate; 4) moderate to severe; and 5) severe. Factors analyzed for the base land use suitability are: degree of slope; height and duration of the Seasonal High Water Table; rockiness of the soil ranging from small stones to surface boulders; and the vegetative cover which includes upland forest, red maple forest, transitional forest and upland field. Factors and combinations already used to eliminate land from the analysis are not included an this suitability determination. This allows an analysis of land use suitability that may be based on the remaining most constraining factor. The intent is to eliminate intradependent combinations, and the still "subjective" process of developing weighting system. The most stringent constraint level becomes the controlling constraint with no constraint level less severe than that constraint.

The basic suitability levels are modified through the next three levels of analysis. The analysis resulting from these three levels is not intended to eliminate land from the analysis as in sieves one and two; rather, it is to provide a means to directly compare the development potential based on a series of alternative land uses and then identifying the most suitable use under a series of conditions. The third sieve modifies 
suitability levels on the degree of physical isolation caused by the wetlands on one or two sides of a parcel and the size of that parcel; the distance and size of a parcel from roads, water lines and sewer lines.

The fourth level of analysis adjusts the developability of a parcel based on nearby land uses. The factors considered include: road access to the parcel, as in what land use does the road system pass through to get to the parcel; and what are the adjacent land uses. Adjacent land uses are based on what land use exists. planed and allowed by zoning. This part of the analysis is needed to consider the impacts of different intensity levels of development on established land uses.

The fifth and final sieve includes regulatory and statutory constraints. The remaining statutory restriction for consideration in the analysis is that imposed by the statutory language of "Sections 23-19-34 and 35 of the R.I.G.L.," that forbids any use of land within 2000 feet of the Central Landfill purchased under those sections for other than industrial purposes. This factor is considered last because it is the most malleable constraint on potential land use included in the analysis.

The end product is the identification of land parcels with their associated degree of constraints as related to different land uses. The intent of this system is to streamline the process by dropping unsuitable parcels of land early in the analysis. This allows the planning process to focus more effectively, and efficiently land parcels that are suitable for development at different intensities.

\section{Summary}

This series of "combination rules" serves to reduce the need for intricate systems of weighting and factoring to determine a parcels suitability for development. It conforms to the unique attributes of the Central Landfill property, rather than forcing a system of analysis that reduces a planners ability to respond to its unique conditions. In other words it is important to adapt a flexible system to the site, rather than adapt the site to a rigid system of analysis. Even though the above system of "combination rules" reduce the need for a complex system of weighting and factoring it does not eliminate the use of numerical combinations or a matrix system in the analysis. By moving through a series of "combination rules" from the most constraining to the least, land is gradually removed from the analysis reducing complexity, time and cost. 


\section{Chapter Four 1996 Land Use Suitability Study}

Chapter Four is the initial land use suitability study completed for the Rhode Island Resource Recovery Corporation in the summer of 1996 . There are two purposes related to the inclusion of this study. The first is to include relavent background information regarding the Rhode Island Central Landfill. The second is providing a means of comparison between the methodology used in that study with that used in the analysis discussed in Chapter Five.

\section{History of the Central Landfill}

On the current RISWMC property there is a 45-year history of landfill operations and earth materials extraction. These activities began in 1952 when part of the Central Landfill was used for the extraction of sand, gravel and stone. Waste disposal activities began in 1955 as a dump for open refuse burning. This use continued until 1962 with the establishment of landfilling operations. Landfill operations were privately operated until December of 1980 when the license to operate the Solid Waste Management Facility was transferred to the Rhode Island Solid Waste Management Corporation (RISWMC) now known as the Rhode Island Resource Recovery Corporation (RIRRC). Beginning in May, 1987 the development of a Gas Recovery Facility began for the collection and cleaning of landfill gas and for electric generation. The passage of "Section 23-19-34 and Section 23-19-35 of the R.I.G.L." mandated the purchase of all residential property within 1000 feet of the statutory landfill and operations area as a buffer zone, and the purchase of residentially zoned property at the option of the owner within 2000 feet of the statutory landfill and operations area. These purchases increased the area of property owned by the RIRRC from 610 acres to 1057 acres.

\section{General Description of Property}

The Central Landfill is located at 65 Shun Pike in Johnston, Rhode Island. In the middle of the property is the actual landfill. There are currently three phases of licensed landfill operations covering 154 acres.

Additionally, there is a pending application for Phase IV landfill development of approximately 45 acres and a proposed Phase $\mathrm{V}$ landfill development of approximately 33 acres. At the loading rate of 750.000 tons per year, the anticipated life-span of all five phases of landfill operations is 20.63 years. It is estimated that with an aggressive recycling operation the life-span could be extended to 25.07 years (Rhode Island Comprehensive Solid Waste Management Plan, as amended July 1996).

Most of the property on which the Central Landfill sits gently descends toward Cedar Swamp Brook which then drains into Upper Simmons Reservoir. A belt of land that extends to the southeast across the northeastem portion of the landfill and the northern two-thirds of the Industrial Park Study Zone drains into the Almy Reservoir watershed. An area of about 10 acres in the extreme western end of the property lies in the Scituate 
Reservoir watershed which is the largest drinking water supply in Rhode Island. Much of the undeveloped property is forested and laced with wetlands. This is particularly true in the area to the west of the Central Landfill, where Cedar Swamp is the dominant physical feature.

The property is bordered by small residential lots along the east and the north, woodland that is residentially zoned in the northeast, and woodland that is industrially zoned in the southwest. Small businesses line the south side of Shun Pike and Scituate Avenue from Greenhill Road east which combine to form the southern boundary. Old Pocasett Road forms much of the eastem boundary with Central Pike providing much of the northern boundary. Even though much of the land around the western third of the Central landfill is still undeveloped there is development pressure in the area. The ongoing residential development exhibits a pattern that is spreading in an east to west manner. In accordance with Johnston Zoning, this development consists of low density detached housing being built along the major road frontages followed by the subdivision of large interior parcels. This development places an increased demand on the same roads and utilities and services that the Central Landfill relies on. Additionally, this residential development results in more residents that will perceive themselves directly affected by land use decisions on the part of RIRRC.

\section{Purpose of Land Use Plan}

The purposes of this plan are to understand the conditions that influence the development of the RIRRC property and to use this understanding to guide land use decisions. There are five general factors and issues that place constraints on the development of the property that were focused on in the analysis. These factors that affect land use decisions include legal issues, environmental factors, physical factors both natural and man-made, and any current and planned landfill operations. An analysis of the constraints related to these factors results in the identification of suitable land use opportunities for different areas of RIRRC property.

\section{SECTION 1. DESCRIPTION OF PROPERTY AND LANDUSE}

\section{General Information}

This section contains a more detailed description of RIRRC property than discussed in the introduction to this chapter. The property was divided into 10 Study Zones (Map 4.1) to provide a format that is easier to analyze sections of land with different characteristics. The criteria used to determine the extent of the Study Zones is based on current and future planned uses, the spatial relationships between the zones and physical/environmental character.

The criteria used to determine the extent of the Study Zones establishes the basis for the land suitability analysis. These criteria are discussed in the following sections on factors, and in the discussion on constraints and opportunities. In addition to these criteria, several other factors were taken into consideration as modifiers 


\section{Map 4.1 Study Zones}

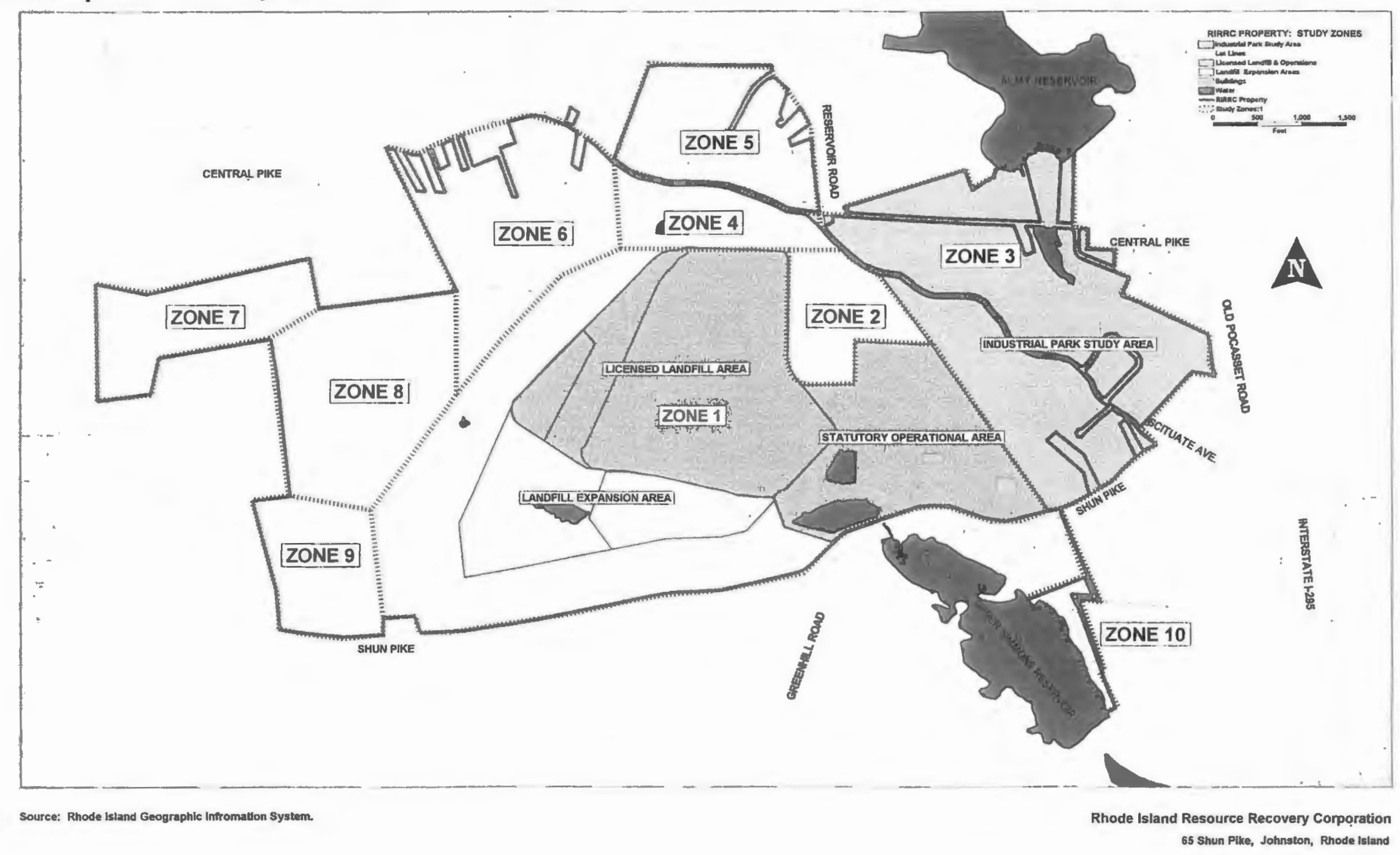


to the initial development suitability analysis which was based on the suitability for more intense development that requires construction. Factors considered were: degree of access, access to utilities, size of identified areas suitable for development, isolation from other parcels, depth of area, proximity to wetlands, enclosure on at least two sides by wetlands, enclosure by non-RIRRC property on at least three sides, proximity to established residential properties, and in the case of Zone 7, the area that lies within the Scituate Reservoir watershed.

In order to analyze the development suitability of the property owned by RIRRC it was subdivided into five classes of overall development constraints. These classes are: "Slight Constraints" which means that there are few factors that limit the development of land; "Slight to Moderate Constraints" which means that there are a few more constraints to development that can range from access to more variable, or steeper topography; "Moderate Constraints" which consider more factors from current, planned, or adjacent uses and more legal constraints; "Moderate to Severe Constraints" also consider more restricted access, degree of isolation, more stringent development restrictions and more defined future uses that limit the feasibility of alternative uses; areas classified with "Severe Constraints" are those that are for practical purposes unsuitable for development, whether because of long-term landfill operations, or due to the presence of environmental/physical factors such as wetlands, surface bedrock, or slopes in excess of 15 percent. In this section each Study Zone is physically described, followed by current and planned land uses, and then a brief discussion of land suitable classes and an initial discussion about land suitable for development.

\section{Description of Study Zones}

\section{A. ZONE I}

1. Description

Zone 1 covers an area of approximately 448 acres. It is comprised of the current and future Landfill areas, the Statutory Operations area, and associated operational activities. Within the Operations area are the Engineering and Operations Building, the Materials Recycling Facility (MRF), the Scale House, Commercial Recycling Area, the Gas Recovery Facility, the Guard Shack, the Sewerage Pump Station, and the Leachate Pretreatment Facility. Throughout the zone is the 600-foot DEM Landfill Development Restriction as per "Section 15.12 of Regulation DEM-DAHM-SW03-92, Rules and Regulations for Solid Waste Management Facilities", and "Section 23-18.9-9.1 (b) (9) of the R.I.G.L." Within Zone 1 are access roads, areas of past gravel extraction, Ponds 1, 2 and 3, Quarry Stream and Cedar Swamp Brook with associated drainage systems. Primary access to the Landfill and Operations area is from Plainfield Pike via Greenhill Road and Shun Pike. Most of Zone 1 and adjacent properties are zoned for industrial uses with isolated parcels in the proximity of Zone 1 zoned residential. 


\section{Current Land Use}

Land use within Zone 1 is centered on the operation of the Central Landfill and will be for the next 20 to 25 years. The Landfill is currently comprised of Phases I, II and IIl. Phase I is the initial 121 acre landfill of which approximately 32 slope acres, which is the actual capped surface area not map area, are capped. Phase II is the 24 acre part of the landfill currently in operation and the 10 acre Phase III is under construction. Phase IV is still in the licensure process and may take an additional one to two years. The combined area of Phases I through III encompasses approximately 154 acres of licensed landfill operations. The pending Phase IV will add an additional 45 acres, and proposed Phase V expansion is expected to add an additional 33 acres which will cover 232 acres out of the 448 acres of Zone 1. As stated in the July, 1996 revision of the Rhode Island Comprehensive Solid Waste Management Plan, the expected life span of Phases II and III at the loading rate of 750,000 tons per year will be 5.09 years, Phase IV 5.7 years and up to 6.71 years with an aggressive recycling program, and Phase $V$ for 9.84 years to 13.27 years. The anticipated life of the Central Landfill can be expected to extend from 20.63 years to 25.07 years.

As per the "Second Revised and Amended Consent Agreement with the RIDEM of August, 1996" to the "Consent Agreement of July. I991" regarding the de-sedimentation operations for Upper Simmons Reservoir there are two series of temporary settling basins for receiving dredgings. These are identified as Dewatering Areas 1 and 2 in the "Southwest Landfill Preliminary Engineering Plans, Appendix to Southwest Landfill Licensing Document, January 1994, Revised April, 1996", to hold and allow the settling of dredging spoils to remove the accumulated inorganic sediment from the Simmons Reservoir dredging operations. The first series of settling basins area located in the southwest borrow area adjacent to Pond 1. Located within the first dewatering area settling basins $1 \mathrm{a}, \mathrm{b}$ and $\mathrm{c}$, and to the east in the Anderson tract is the second dewatering area with settling basins $2 \mathrm{a}$ and $\mathrm{b}$. These dewatering areas and other erosion control measures are detailed in the "Erosion and Sediment Control Plan for Landfill Facility Operations, July, 1996. The water from dredging operations will flow through the series of settling basins before flowing into Ponds 1 and 2 which then discharge into Cedar Swamp Brook. Adjacent to the first dewatering area and Pond 1 is the designated dredge spoils area.

\section{Planned Land Use}

In addition to future landfill expansion the resumption of gravel extraction operations are planned to within 100 feet of the south property line along Shun Pike. This is to allow theconstruction of Phase IV, the relocation of Cedar Swamp Brook and provide necessary construction materials. The construction of Phase IV and the brook relocation plan as identified in the "Southwest Landfill Preliminary Engineering Plans, Appendix to Southwest Landfill Licensing Document, January 1994, Revised April, 1996" calls for the elimination of Pond 1 and the establishment of five additional ponds along the relocated Quarry Stream and Cedar Swamp Brook. 


\section{Land Suitable for Development}

The bulk of the land within Zone 1 is severely constrained for development altematives. The chief of these factors is related to the current and future landfill, and landfill related activities most of which are located within the 600-foot DEM Landfill Development Buffer. Other severe constraints are related to wetland and surface water protection. In the extreme southwest is an area with "moderate to severe constraints" related to its isolation from developable areas and its designation for future gravel extraction. In the southeast of Zone 1 is the Statutory Operational Area most of which is moderately to severely constrained. Within this area are the Materials Recycling Facility, the Engineering and Operations Building and other areas developed for landfill related activities. This area is slightly less constrained for development due to its adaptability for future expansion and post-landfill activities. The 20 to 25 year time-frame for Central landfill and the need for maintaining operational activities limits future development options. North of the Engineering and Operations Buildings is an area of approximately six acres that is only moderately constrained because of its nondeveloped nature. The primary constraint here is related to the surface boulder deposits.

\section{B. ZONE 2}

1. Description

Zone 2 covers an area of approximately 36 acres that is enclosed by RIRRC property. The 600 -foot DEM Landfill Development Restriction extends southward through the western portion of the zone. Within the zone is an area with a deposit of surface boulders known as the "Round Rocks" where boulders were excavated leaving a surface of boulders and exposed rock. The eastern part of the zone descends towards Scituate Avenue with a slope ranging from 8 to 15 percent beginning around the treeline. This slope reduces the access to the zone from Scituate Avenue. The slope serves to enhance the visual buffering capacity of the wooded buffer. As part of the original RIRRC property Zone 2 is zoned for industrial use.

\section{Current Land Use}

There are currently two primary land uses within Zone 2. The first of these is landfill access provided by the access road that runs along the eastern edge of the landfill. The second of these as a staging area for construction materials, particularly regarding recycled asphalt for road surfacing. This area occurs in the northern end of the zone along the wooded edge before the slope descends towards Scituate Avenue.

\section{Planned Land Use}

Future land uses include the continued use as a staging area for construction materials, recycled asphalt, and as the likely location for staging operations related to the capping of the hazardous materials hot-spot along the east side of the actual landfill. A long-term possible use is an eastward expansion of the landfill operations into the zone. The viability of this use would be contingent upon the future development and use of Zone 3 
particularly regarding the outcome of the Industrial Park Feasibility Study. The future value of the wooded slope is contingent upon the future use for Zone 2 and Zone 3.

\section{Land Suitable for Development}

Based on the level of development, landfill activities, and the 600-foot DEM Landfill Development Restriction, Zone 2 is essentially divided into two areas defined by levels of constraints. The constraint level to the west of the 600-foot Development Restriction is severely constrained by being within an area with active landfill operations and within the 600 -foot Development Restriction. The rest of Zone 2 is moderately constrained by some slopes in the 8 to 15 percent range, and its proximity to current landfill operations. The future level of development constraints is dependent on any eastward expansion of the landfill. An eastward expansion would reduce the suitability of development by moving the 600 -foot buffer eastward.

\section{Zone 3 \\ 1. Description}

Zone 3 covers an area of approximately 196 acres with 172 of these being owned by RIRRC. This is the area identified as the subject for the Industrial Park Feasibility Study. Zone 3 is split along the watershed line between Almy Reservoir to the north and Simmons Reservoir to the south. The part of the zone within the Almy Reservoir watershed drains towards two wetland areas. The first of these wetlands drains the northwest part of the zone along a northeasterly course to Almy Reservoir. The second and more significant wetland drains the bulk of the zone along a drainage way that extends from Macera Circle north to Almy Reservoir. This wetland includes an area of open water and marsh.

Most of the zone is forested with concentrations of residential development along Central Pike in the north, and a concentration around Scituate Avenue and Macera Circle in the south. Most of these residential units are owned and rented out by RIRRC with some open lots cleared of structures in response to Sections 23-1934, 34.1 of the R.I.G.L. These Statutes mandated the purchase of properties within the 1000-foot buffer and the demolition of structures on those properties within the buffer. Zone 3 is primarily zoned residential with 5 parcels zoned for industrial use in the south. The property to the south of Zone 3 is zoned for industrial use, with the areas adjacent to the north and east boundaries zoned residentially. Access to the zone in the north part of Zone 3 is from east and west along Central Pike through residential areas. In the south it is along Shun Pike and Scituate Avenue through both residential and industrially zoned areas. A north to south connection is provided along the east edge of the zone by Old Pocasett Road, and potentially along the closed off section of Scituate Avenue which is paved along the most southern third of its length within the zone. 


\section{Current Land Use}

Uses within Zone 3 include the continued use of residential property. In the southwest part of the zone adjacent to the Statutory Operations Area is an area of past extraction soil operations, and is currently used for staging daily cover material and the storage of shredded wood some of which is from demolition activities.

\section{Planned Land Use}

Future land use within Zone 3 is dependent upon the Industrial Park Feasibility Study findings regarding its potential for development as an Industrial Park. In the meantime continued use of the residential units and staging/storage operations can be expected.

\section{Land Suitable for Development}

The bulk of the land within Zone 3 exhibits slight or slight to moderate constraints. An area in the southwest corner of the zone is moderately constrained due to past excavation activities, and its current use for staging daily cover materials and storage of construction debris. In the northeast part of Zone 3 is an area of moderate constraints. Factors affecting this level of classification is its nearness to wetlands and the adjacent established residential areas, and the shallow lot depths to the east of the wetlands. Within the areas of severe constraints related to wetlands, surface bedrock and properties that are not owned by RIRRC.

D. Zone 4

1. Description

Zone 4 is an area of approximately 34.7 acres that includes the northern extent of the 600 -foot DEM Landfill Development Restriction. The zone is mostly wooded with cleared areas in the south associated with landfill operations. Within the Operations Area is Pond 4 which is the main drainage basin for the northern part of the landfill and the central part of the zone. In this area a wetland coverage that extends northward to and eastward along Central Pike was identified through RIGIS wetland coverage. Pond 4 drains into Quarry Stream which drains southwest to Cedar Swamp Brook downstream of Cedar Swamp and the Swimming Hole. The east and west ends of the zone descend along slopes of 8 to 15 percent towards Almy Reservoir and Quarry Stream. Access to Zone 4 from RIRRC property is via the landfill access road, and off-site access is from Central Pike through residentially zoned areas. The parts of Zone 4 that are part of the original RIRRC property are zoned for industrial use, while the properties purchased in response to Section 23-19-34 of the R.I.G.L. are currently zoned residential.

\section{Current Land Use}

A major function of Zone 4 is its use as the 600 -foot DEM Landfill Development Restriction and as a wooded visual buffer. Functions related to landfill operations include the management of drainage and providing access to the landfill. 


\section{Planned Land Use}

Potential future use includes use as a staging area for landfill operations and the continuation of current activities.

\section{Land Suitable for Development}

Land within Zone 4 is either severely constrained, or moderately constrained with the exception of a small area in the northwest adjacent to Zone 6 that is moderately constrained. The severe constraints are related to wetland and surface water protection and operational areas that lie within the 600-foot DEM Landfill Development Restriction. The moderately to severely constrained areas have constraints that are primarily related to the 600-foot DEM Landfill Development Restriction and the 1000-foot Landfill Buffer.

\section{E. ZONE 5}

\section{Description}

Zone 5 is a residentially zoned area of approximately 61.7 acres of which 57.6 acres were purchased in response to Sections $23-19-34$, and 35 of the R.I.G.L. The zone is primarily wooded with much of the interior covered by a wetland that limits the areas suitable for development along the edges and Alaina Drive. Slopes in the 8 to 15 percent range cover much of the zone along Reservoir Drive. Along Reservoir and Alaina Drive are occupied residential units, several of which are owned and rented out by RIRRC. In the southern part of the zone some residential units were demolished that were within the 1000-foot Statutory Landfill Buffer.

Access to the zone is through residential areas along Central Pike from the east and west, and along Reservoir Avenue from the north with Woodlake Park lying across it from Zone 5.

\section{Current Land Use}

Zone 5 is currently being used for residential purposes.

\section{Planned Land Use}

There is currently no plan for alternative uses other than the continuation of residential use.

\section{Land Suitable for Development}

The severe constraints in Zone 5 are those related to wetlands protection, surface bedrock and residential properties not owned by RIRRC. Moderately to severely constrained areas are the non-wetland areas within the 1000-foot buffer along Central Pike. Much of the non-wetland area between the 1000-foot Landfill Buffer and the 2000 -foot Development Restriction are considered moderately constrained. These areas are constrained by the development restrictions in "Section 23-19-35 and 35.1 of the R.I.G.L." that conflict with the nearby residential development of the immediate area. Otherwise without these combined constraints this area would be considered more developable. Within the southeast corner of Zone 5 that by virtue of its 
isolation from the rest of Zone 5 by wetlands and its proximity to the Industrial Park Study Area that may be more suitable for development within the imposed legal constraints. It is of sufficient size and isolation from residential development to support consideration for development.

\section{F. ZONE 6}

\section{Description}

Zone 6 is an area of approximately 96.5 acres of which about 86.7 acres of residentially zoned property were purchased by RIRRC in response to Sections 23-19-34, and 35 of the R.I.G.L. The primary use is for staging and stockpiling construction materials and as a wooded visual buffer from properties along Central Pike. This area along Central Pike and north of it is subject to increasing residential development. On the northern edge of the zone are several residential properties only a few of which are owned and rented out by RIRRC. The privately owned parcels lay just beyond the 2000 -foot line. There are two main areas of land within the zone that can be defined by use and topography. Approximately 40 acres of reasonably level ground is occupied by staging operations for landfill construction materials. In the southwest of the zone is a cleared area that was used in the past for quarrying operations. Much of this small area was excavated to bedrock resulting in little soil to support natural regeneration of forest as has occurred in other parts of RIRRC property. A thin strip of wooded edge lies along the western boundary that includes small areas of wetland that are part of Cedar Swamp. To the east of the staging area the slope descends at a range of 8 to 15 percent. This area is wooded and contains small wetland areas. Access is from RIRRC property and a "paper road" from Central Pike which passes through residentially zoned areas.

\section{Current Land Use}

Current landuses within Zone 6 are as a staging area for landfill construction materials, and as a wooded visual buffer to screen the Central Landfill from the properties along Central Pike.

\section{Planned Land Use}

The current use as a staging area for landfill construction materials is expected to last indefinitely. There are currently no plans for alternative use.

\section{Land Suitable for Development}

The areas of severe constraints within Zone 6 are related to the wetlands related to the small isolated wetlands, Cedar Swamp and those properties along Central Pike not owned by RIRRC. The area inside the 1000-foot Landfill Buffer is moderately to severely constrained, because of landfill activities and legal constraints on development and landfill expansion to the west and north. The property owned by RIRRC along Central Pike is moderately to severely constrained by the narrow fingers of RIRRC property that extends to Central Pike. The bulk of the zone is moderately constrained by slopes in the 8 to 15 percent range through much of the 
eastern part of the zone. Much of the western part of the zone is moderately constrained even though it includes ongoing landfill operations. This is due to the overall suitability for development which is primarily, because it is cleared, flat and large. After staging operations are completed it is physically and visually isolated from daily landfill activities. These reasons along with easy off-site access make it suitable for future development.

\section{G. ZONE 7}

1. Description

Zone 7 is an area of approximately 49.3 acres zoned for industrial use. The adjacent lands to the north and west are zoned residential while those to the south are zoned industrial. The zone is almost all forest with an area of wetlands in the eastern third of the zone that is part of the Cedar Brook Swamp drainage system. In the extreme western part of the zone are smaller areas of wetlands. Also in the far western part of the zone is an area of approximately 10 acres that lies within the Scituate Reservoir watershed. The wetlands within the zone and on adjacent properties limits access from both RIRRC property and from off-site.

\section{Current Land Use}

There is currently no active land use in Zone 7.

\section{Planned Land Use}

There are currently no planned land uses for Zone 7.

\section{Land Suitable for Development}

Most of Zone 7 is either severely constrained, or moderately to severely constrained. This is due primarily to constraints related to wetlands and the large areas of soils subject to "seasonally high water tables".

Additionally, the areas that exhibit less physical constraints are limited by size, lack of access and utilities. In the extreme west there are additional constraints related to slopes in excess of 15 percent and approximately 10 acres that lie within the Scituate Reservoir watershed. Between this area and the wetlands to the east is an area that is generally suitable for development, but its overall suitability for development is constrained by lack of access, utilities, and its proximity to wetlands and the Scituate Reservoir watershed.

\section{H. ZONE 8}

1. Description

Zone 8 is an area of approximately 83.1 acres zoned for industrial use as are adjacent properties. The zone is predominantly wooded wetlands which limits development possibilities and access. Within the zone are several stream beds that drain into the Cedar Swamp Brook drainage basin. The eastern edge of the zone was set at 600 feet to match the 600 -foot DEM Landfill Development Restriction around the current and planned Phase IV landfill expansion. 


\section{Current Land Use}

There is currently no active land use in Zone 8.

\section{Planned Land Use}

There are currently no planned land uses for Zone 8 .

\section{Land Suitable for Development}

The land within Zone 8 is either severely constrained, or is moderately to severely constrained with a small area of moderate constraints in the northeast corner adjacent to Zone 6 . The constraints are primarily related to wetlands, soils subject to a "seasonally high water table", more suitable land isolated by wetlands and a lack of access and utilities.

\section{ZONE 9}

\section{Description}

Zone 9 is an area of approximately 41.5 acres that is zoned for industrial use as are adjacent properties. A large part of the zone is covered by woodlands and wetlands that form an inverted $U$ around the center of the zone. The zone drains northward toward the Cedar Swamp drainage basin. Access is either direct from Shun Pike, or more limited access from RIRRC property across wetlands.

\section{Current Land Use}

There is currently no active land use in Zone 9.

\section{Planned Land Use}

There are currently no planned land use for Zone 9.

\section{Land Suitable for Development}

Zone 9 has minimal slope constraints, good location, direct access and access to utilities, but these positive attributes are insufficient to counter-balance the overall severe and "moderate to severe" constraint levels. Based on wetlands and soils coverage all, but about one-half of an acre is either wetlands or subject to a "seasonally high water table". This would require sufficiently high land values to overcome the costs associated with developing an area prone to wetness. Without such financial incentive the most suitable use for this land is conservation related. 


\section{J. ZONE 10}

1. Description

Zone 10 is a narrow linear piece of property of 7.8 acres that is 114 feet deep at its most narrow point and with a southern property line extending 121 feet back from Upper Simmons Reservoir. There are about 1745 feet of shoreline along Upper Simmons Reservoir with a small wetland area along a cove at the northern end of the site. The zone is wooded with cleared areas where residential units once stood. The zone has limited access via Simmons Lake Road coming south off Shun Pike. Zone 10 is zoned residential except for the most northern lot which is zoned industrial. These properties were purchased and cleared in response to Section 2319-34, and 34.I of the R.I.G.L. Adjacent properties are zoned residential with those north of the zone being industrially zoned.

\section{Current Land Use}

There is no current long-term use associated with Zone 10, but it is currently in use as a temporary staging area for dredging operations

\section{Planned Land Use}

There are currently no plans for the use of Zone 10. Future use as an access road for an Industrial Park has been proposed, but is dependent upon the Industrial Park Feasibility Study conclusions and agreement with Narragansett Electric regarding the use of the power transmission line right-of-way for an access road.

\section{Land Suitable for Development}

The 50 foot wetland buffer along the shore of Upper Simmons Reservoir reduces land that was possibly developable to almost undevelopable. At its narrowest point it reduces developable frontage from 114 feet to 64 feet. This would be tolerable if residential development were allowed, but in light of the development restrictions place on development by "Sections 34, 34.135 and 35.I of the R.I.G.L. OF 1989", this option is not allowed. Additionally, it has been proposed for study as a possible access route for an Industrial Park should such a park prove feasible. In the northern end is an area that is for the most part suitable for development. In light of overall constraints a conservation related use is most suitable for Zone 10. 


\section{SECTION 2. SOILS AND GEOLOGY}

\section{General Information}

\section{A. SOILS}

The soils that occur on RIRRC property are grouped into four general categories based on constraints to development ranging from slight to undevelopable following the grouping established by "Everett Stuart of the Soil Conservation Service in July, 1992". Soils in Group A are generally suited to development. The constraints range from slight to moderate with stoniness and slope being the primary constraints with slow permeability in the substratum being limited to $\mathrm{PbB}$. The suitability for development of Group $\mathrm{B}$ soils is moderate due to constraints based on the Seasonal High Water Table (SHWT) and slow permeability. Group C soils are constrained by slopes in excess of $15 \%$, shallow soil, ledge and surface outcrops that result in low suitability levels for construction. The soils in Group D are unsuitable for development because of water levels at, or near the surface for significant periods of the year and are classified as hydric soils. A more complete description of the soil groups and soils found on RIRRC property is provided in the following section.

\section{Descriptions of soil constraint groups}

Group A: The soils in this group are generally suited to development. Some soils in this group have stronger constraints on development and need to be evaluated individually. The constraints consist of: 1. very rapidly permeable soils, which have higher potential for groundwater contamination which is in general not applicable on RIRRC soils, 2. slowly permeable soils which tend to have greater septic system failure rates and other drainage related problems, 3. extremely stony soils which are expensive to excavate and grade for development. Also included are disturbed areas which are often suitable for residential development, which also need site specific evaluation. Examples include gravel pits, cut and fill areas, and paved areas. The following table contains a description of the Group A soil types found on RIRRC property. 
Table 4.1 Group A Soil Descriptions

\begin{tabular}{llll}
\hline Soil Type & \multicolumn{1}{c}{ Description } & \multicolumn{1}{c}{ Slope } & Primary Limitations \\
\hline $\mathrm{ChB}$ & Fine sandy' loam & 3 to 8 percent & stoniness \\
$\mathrm{ChC}$ & Fine sandy loam & 8 to 15 percent & stoniness. slope and erosion hazard \\
$\mathrm{CkC}$ & Very stony fine sandy loam & 8 to 15 percent & slope. stones. boulders and erosion hazard \\
$\mathrm{HkC}$ & Gravely sandy loam & rolling & stoniness and slope \\
$\mathrm{PaB}$ & Fine sandy loam & 0 to 8 percent & slow permeability in substratum \\
$\mathrm{PbB}$ & Very stony fine sandy loam & 8 to 15 percent & slow permeability in substratum. stones and boulders \\
$\mathrm{Pg}$ & Pits. gravel & & \\
$\mathrm{UD}$ & Urban land complex & & \\
\hline
\end{tabular}

Group B: The soils in this group have a SHWT at a depth of 1.5 to 3.5 feet from the surface for significant periods of the year. Many of these soils have additional constraints, such as slow permeability or, in a few instances very rapid permeability. The following is a brief description of the Group B soil types found on RIRRC property.

Table 4.2 Group B Soil Descriptions

\begin{tabular}{llll}
\hline Soil Type & \multicolumn{1}{c}{ Description } & Slope & \multicolumn{1}{c}{ Primary Limitations } \\
\hline SuB & Very stony fine sandy loam & 0 to 8 percent & seasonal high water table. Surface rocks and boulders \\
WoB & Very stony fine sandy loam & 0 to 8 percent & slow permeability and seasonal high water table \\
\hline
\end{tabular}

Group C: Soils in this group have slopes in excess of 15 percent, and/or shallow depths to bedrock. Steep slopes increase the potential for soil erosion during construction, and make construction of on-site septic systems difficult. Shallow soils and rock outcrops impair the construction of roads, buildings, buried utilities, and on-site septic systems. The following is a brief description of the Group C soil types found on RIRRC property.

Table4.3 Group C Soil Descriptions

\begin{tabular}{llll}
\hline Soil Type & \multicolumn{1}{c}{ Description } & \multicolumn{1}{c}{ Slope } & \multicolumn{1}{c}{ Primary Limitations } \\
\hline $\mathrm{CeC}$ & fine sandy loam. very rocky & 3 to 15 percent & slope. stoniness and surface bedrock \\
$\mathrm{ChD}$ & very stony fine sandy loom & 15 to 25 & steep slopes \\
$\mathrm{LgC}$ & gravely sandy loam. very rocky & 3 to 15 percent & shallow depth to bedrock and surface bedrock \\
\hline
\end{tabular}

Group D: These soils have water at, or near the surface for significant periods of the year. These soils are generally classified as "hydric" soils. The following is a brief description of the Group D soil types found on RIRRC property.

Table 4.4 Group D Soil Descriptions

\begin{tabular}{llll}
\hline Soil Type & \multicolumn{1}{c}{ Description } & \multicolumn{1}{c}{ Slope } & \multicolumn{1}{c}{ Primary Limitations } \\
\hline Aa & Muck soil. hydric soil & 0 to 8 percent & high water table. high water capacity and low surface strength \\
Rf & $\begin{array}{l}\text { Extremely stony fine sandy loam. } \\
\text { hydric }\end{array}$ & 0 to 8 percent & high water table and slow permeability \\
& &
\end{tabular}

\section{B. SURFACE GEOLOGY}

The surface geology on RIRRC property consists of five types of geologic deposits. The most extensive deposits are "ground moraine deposits of till" (Qgm"). These deposits are comprised of unsorted sands, 
stones, silt, clay and boulders with scattered deposits of stratified materials. These deposits are found in all study zones, but are of particular importance in Zone I where much of the original "Qgm" deposit has been extracted for gravel and future extraction operations are planned. A series of "quartenary swamp deposits" (Qs), bordered by "kame terrace outwash deposits" (Qkt) where the Qs deposit turns easterly and "valley train outwash deposits" (Qvt) at the head of the main Qs deposit in Zones 4 and 5, roughly bisect the RIRRC property by extending from Zone 5 south through Zone 4 into Zone 1 then in a general southeast direction to Upper Simmons Reservoir. "Qs" deposits are comprised of silt, sand and partially decayed organic matter of 0 to 8 feet in depth and underlies much of the recognized wetland areas on RIRRC property. "Qkt" deposits consist of poorly sorted to well sorted deposits of sand and gravel, much of theses deposits have already been excavated or lie under the landfill or the statutory operations area. The single "Qvt" deposit of well sorted sand and gravel lies under the northwestern corner of the landfill and Zone 4 . Throughout the western portion of the site (Zones 7, 8 and 9) are five Qs deposits of varying size. The main Qgm deposit in the eastern portion of the RIRRC property is split into three sections by a linear deposit of "round rocks" that extends eastward through Zones 1 and 2, and into Zone 3, while a finger extends southward to Upper Simmons Reservoir. The "round rocks" is an area that is typified by an abundance of boulders at the surface, (GZA, Central Landfill Remedial Investigation Report).

\section{BEDROCK GEOLOGY}

The Bedrock geology is typified by moderately severely weathered and highly fractured bedrock to "Rottenstone" a very dense residual soil decomposed to quartz, feldspar grains, and clayey silt, and the parent material of Scituate Granite Gneiss showing varying degrees of weathering and fracturing which range from very slight to very severe. This material underlies the RIRRC property and most of the region within the Town of Johnston(GZA, Central Landfill Remedial Investigation Report).

\section{Description of Soils and Geology in Study Zones}

The following section describes the soil and subsurface geology conditions as pertain to each of the study zones. Map 4.2 shows the dispersion of the soil types, the levels, and types soil and slope constraints on development.

\section{A. ZONE 1 \\ 1. Soils}

The original soils of Zone 1 have been significantly altered by the excavation of soil and gravel for construction and cover materials, the development of the landfill, and by development in the operations area. While some of the original soils considered suitable for development exist with little, or no alteration much of the soils and underlying materials along Shun Pike have been identified for future extraction operations for landfill construction materials and landfill expansion. Other areas of such soils that are suitable for 


\section{Map 4.2 Soil Constraints}

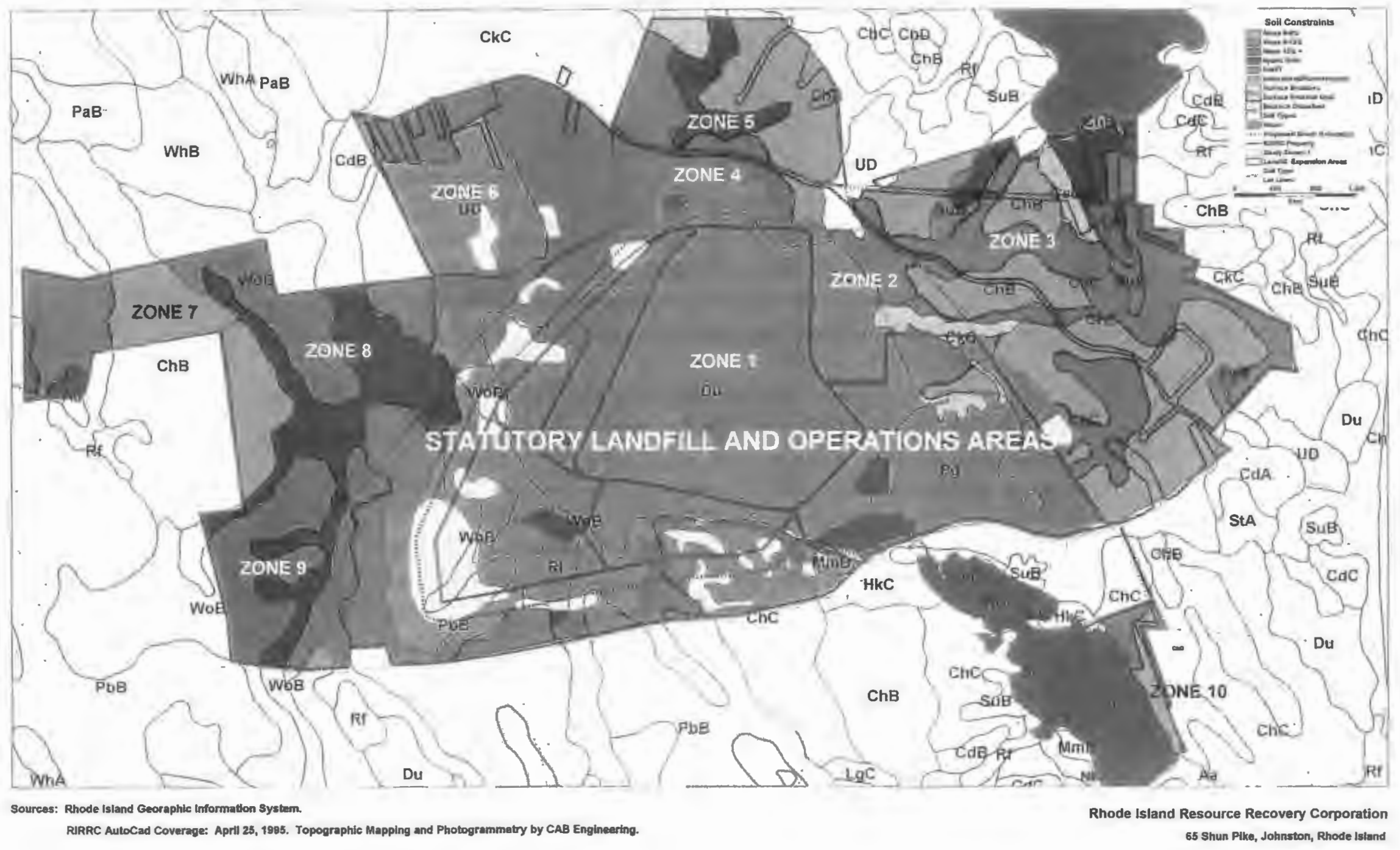


development lie within the statutory operations area should the expansion of operations facilities be deemed desirable.

2. Surface geology

The original surface geology of Zone 1 included all five types of deposits found on RIRRC property. The surface geology has been significantly altered by landfill and excavation operations. Within the southern part of the zone along Shun Pike is an area identified for the future extraction of earth materials for the construction of expanded landfill activities.

\section{B. ZONE 2}

1. Soils

Zone 2 soils are comprised mostly by soils that are generally considered suitable for development in the eastern part of the zone. The western part of the zone is comprised of altered soils related to landfill activities. The soils that are considered suitable for development are limited mainly by surface stoniness and slope. An area with surface stones and boulders that stretches across the center and the south of the zone. In this part of the zone there are areas that have been excavated for construction materials and boulders. The soils within the zone are of the same types that much of the landfill was built on. While these soils are in general considered unsuitable for landfill when the Soil Conservation Service developed the Soil Survey in 1979, technologies and methods used such as those being used to construct current and planned future expansions reduce the seepage hazard associated with these soils.

\section{Surface Geology}

The surface geology in the zone is primarily comprised of moraine deposits to the north and a deposit of surface boulders referred to as Round Rocks in the south. In the area of round rocks, boulders have been excavated leaving a surface of boulders and exposed rock.

\section{ZONE 3}

1. Soils

Most of the soils Zone 3 are soil types that are generally considered suitable for development with a variety of moderate restrictions. The primary limitations are related to slope and stoniness, and one soil type with the additional constraint of surface stones and boulders that extends into the center of zone from the west. In the zone are areas of soils that are associated with the wetlands and have a Seasonal High Water Table that either saturates the soil, or may be apparent from September to June. In the southwest part of the zone is an area that has been altered by excavation, the staging of construction materials and daily cover, and the storage of shredded wood debris. 


\section{Surface geology}

The surface geology of Zone 3 is predominantly comprised of moraine deposit with a band of Round Rocks that extends into the center of the zone from the west. The "OU2 Study" indicates that this band enters into Zone 3, but does not map the full extent of this deposit in Zone 3. The actual extent of this deposit poses one of the more important constraints to development within Zone 3. To determine the extent of constraints on development related to this deposit a survey is needed to delineate the actual deposit of Round Rocks in the zone.

\section{ZONE 4}

\section{Soils}

The soils of Zone 4 are generally considered suitable for development with limitations related to surface stoniness, rockiness and slope. While there are no soils within Zone 4 associated with wetlands, extending northward from Pond 4 is an area that is identified by RIGIS wetlands and landcover coverage as a wetland. While these are not classified as wetland soils the RIGIS coverage does raise the possibility of an additional constraint related to seasonally wet soils. The areas of the zone to the east and the west of this area have limitations related to slope that range in the 8 to 15 percent range.

\section{Surface Geology}

The surface geology in Zone 4 consists primarily of a "valley train" deposit of sorted sands and gravel in the western part of the zone that underlies Pond 4 and the areas identified as wetlands by RIGIS wetland and landcover coverage. To the east of this area the zone is underlain by moraine deposits.

\section{E. ZONE 5}

1. Soils

Within the middle of Zone 5 are hydric soils associated with wetlands that are considered unsuitable for development because of a seasonal high water table of $0-1.5^{\prime}$ that may be apparent or perched for September through June. The north part of the zone includes an area of soils that are poorly suited to development due to shallow depth to bedrock and surface outcrops. Additionally there are areas within the zone that have additional constraints related to slopes in the 8 to 15 percent range. Within the zone there are two primary areas of soils suitable for development. These soils are primarily limited by surface stoniness and in the west by rockier soil. These soils essentially make up the outer edges of the site roughly matching up with the subdivision of the zone. 


\section{Surface Geology}

Within Zone 5 are two primary types of deposits. The first of these underlies the wetlands in the western third of the zone. This is a deposit comprised primarily of silt, sand, clay and partially decayed organic matter. The remaining part of the zone is part of the moraine deposits that are the primary geologic deposit in the area.

\section{F. ZONE 6}

1. Soils

The dominant soil within Zone 6 is considered to be developable, but has limitations related to surface stones, boulders and slopes that may range from 8 to 15 percent. In the extreme northwest comer are small areas of soil that have fewer constraints that border on what is considered an urban developed soil where landfill construction materials are staged. This section of the zone may have the fewest constraints related to soil, but requires a site specific survey to determine the actual suitability for development.

\section{Surface Geology}

The surface geology for Zone 6 is part of a moraine deposit. The eastern part of the zone has a small strip of the "valley train" deposit that underlies the adjacent portion of Zone 4.

\section{G. ZONE 7}

1. Soils

The soils of Zone 7 include hydric soils that are considered unsuitable for development because of a SHWT high water table that may be apparent from September to June, and non-hydric soils subject to SHWT. Much of the zone is comprised by soils that are considered suitable for development, but are limited by slow permeability, surface stones and boulders. The areas of the zone that are subject to the greatest limitations are in the east where part of Cedar Swamp wetlands system stretches northward, and branches westward into the center of the zone. In the extreme western part of zone where there are wetland soils and a small area of shallow soils, slopes in the 8 to 15 percent range, and a small area along the western boundary in excess of 15 percent.

\section{Surface Geology}

The surface geology for Zone 7 is primarily moraine deposits, with a small areas of Quartenary Swamp deposits underlying some of the wetlands within the zone.

\section{H. ZONE 8}

1. Soils

A significant part of the soils within Zone 8 are hydric and non-hydric soils related to the large area of wetlands that lie within the zone. The limitations of these soils are related to a high water table and a 
seasonally high water table that may be apparent, or perched from September through June. The remaining soils are considered suitable for development, but have limitations related to slow permeability, surface stones and boulders.

\section{Surface Geology}

The surface geology consists primarily of moraine deposits bisected by swamp deposits that underlie much of Cedar Swamp.

\section{ZONE 9}

\section{Soils}

Zone 9 consists of large areas of hydric soils that are not suitable for development that are associated with the wetlands in the zone. The remaining soils are considered suitable for development, but have constraints related to a SHWT, slow permeability, surface stones and boulders.

\section{Surface Geology}

Zone 9 consists of two types of surface deposits found on RIRRC property. These are moraine deposits and swamp deposits underlying some of the wetlands in the center of the zone.

\section{J. ZONE 10}

1. Soils

The soils of Zone 10 are generally considered suitable for development, but are limited by slopes of 8 to 15 percent, stoniness and instability on excavated slopes.

\section{Surface Geology}

The remedial Survey performed by GZA indicates that the northern part of Zone 10 is comprised of moraine deposits and a finger of the Round Rocks deposit that extends southwards. The bulk of Zone 10 was not surveyed for the Remedial Investigation, but based on area geology it should be composed mainly of moraine deposits. Determination of the actual extent of these deposits requires a site specific survey.

\section{SECTION 3. WETLANDS AND SURFACE WATER}

\section{General Information}

Located within and adjacent to RIRRC property are five surface water categories that include both year-round and seasonally wet areas. These five categories are wetlands, streams, man-made drainage channels, ponds and reservoirs. The RIRRC property drains into the three watersheds of Simmons Reservoir which receives most of the drainage from RIRRC property and all, but the most northwest part of the Central Landfill which 
along with Zone 5, most of Zone 3 and much of Zones 2 and 4 are part of the Almy Reservoir watershed. In the extreme western part of Zone 7 is an area of about 10 acres that lies within the Scituate Reservoir watershed. The watershed boundaries and the drainage patterns for most of the RIRRC property are included in the "Erosion and Sedimentation Control Plans, November 1995, Revised: December, 1995. The RIGIS coverage is based on 1988 aerial photography. The RIRRC ACAD coverage from CAB Engineering is from April, 1993, as is the preliminary identification by GZA for the "Central Landfill Ecological Characterization Operable Unit 2, Remedial Investigation - Task 2, Johnston. Rhode Island" (OU2 Study). The extent of each category of surface water and sources used for the Wetlands and Surface water classification is shown on Map 4.3.

\section{Wetlands}

A major component of the "OU2 Study" involved flagging and surveying to delineate the wetland boundaries based on vegetation, hydrology and periods of inundation which were in accordance with the "1987 U.S. Army Corps of Engineers Wetland Delineation Manual". The remaining areas identified as wetlands are based on RIGIS coverage that are not field verified. In order to accurately determine the extent of the remaining wetlands a survey comparable to that produced by GZA for the "OU2 Study" would be required. Most of the wetlands located on RIRRC property are seasonally wet with some areas that are more persistently wet as in Cedar Swamp and the marsh in Zone 3.

According to the "OU2 Study" the federal classification of wetlands that is applicable to the RIRRC property surveyed is "Palustrine, Forested, Broad Leaved, Deciduous, Seasonally Saturated" (PFOIE). There are several small streams with wetlands areas that are classified as "Areas Subject to Storm Flow" (ASSF) under the Rhode Island Department of Environmental Management (DEM) classification system. The wetlands delineated by the GZA in the "OU2 Study" include the part of Cedar Swamp that lies in Zones 1, 7, 8 and 9. Other delineated wetlands include the small isolated wetlands along Shun Pike in Zone 1; the wetland in the northwest part of Zone 3; the finger of wetland the wetland in Zone 5 that extends eastward toward Reservoir Avenue; and, the narrow wetland strip that runs along the shore of Upper Simmons Reservoir in Zone 10. Wetlands within RIRRC property which need verification include the small wetlands identified by aerial photography in Zones 4 and 6, the eastern wetland area in Zone 3, and the part of the wetlands in Zone 5 that extends northward.

\section{Streams}

There are two main streams on RIRRC property that can be considered as three different channels. Cedar Swamp Brook is the only stream that tends to have sufficient water flow to support a relatively stable aquatic environment. Cedar Swamp Brook can be subdivided into two sections: the first of these is upstream from the Swimming Hole where it meanders through Zone 8 receiving no direct runoff from the landfill, the second is 


\section{Map 4.3 Surface Water and Wetlands}

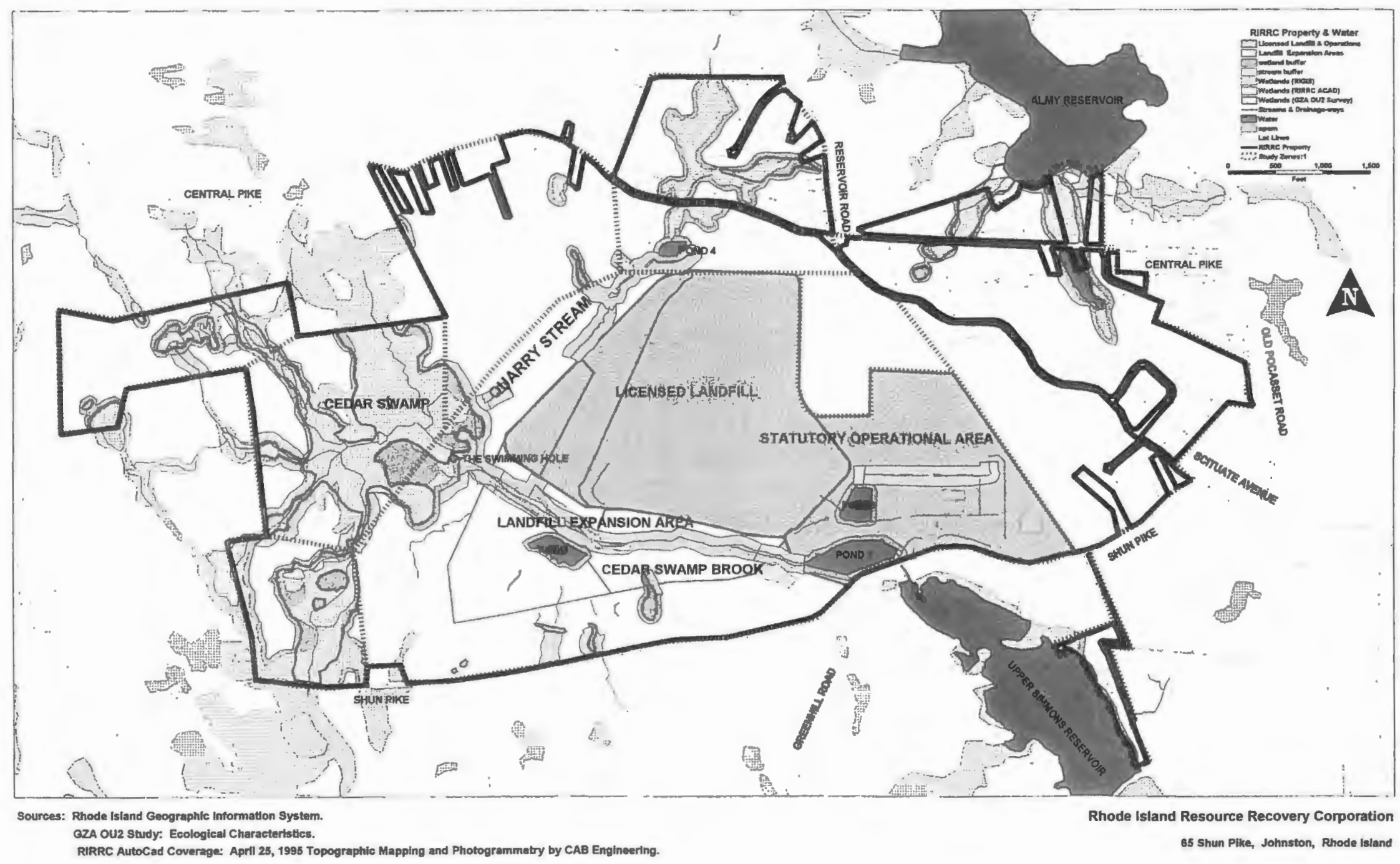


downstream from the Swimming Hole where it is channelized and receives runoff from the landfill. The third channel is the relocated Quarry Stream that has been cut into the bedrock and is essentially a drainage channel that receives drainage from the western and northern portions of the landfill. The remaining streams throughout the property tend to be of an intermittent nature and subject to storm flow.

\section{Drainage Channels}

Through out the property are a series of drainage channels, swales, culverts and drains to manage runoff. Drainage channels of particular importance are those that drain the active landfill operations area into Quarry Stream, the channelized section of Cedar Swamp Brook south of the landfill area, and Ponds 1, 2, 3 and 4.

\section{Ponds}

There are currently a series of four ponds used to manage drainage from the landfill operations area, these are Ponds 1, 2, 3 and 4. Additionally, there are two series of temporary ponds used as settling basins for receiving the dredgings from the Upper Simmons Reservoir dredging operations. Currently in use is a series of two ponds (Ponds 2a and b) that receive the dredgings and ultimately drain into Pond 2. In the southwest part of Zone 1 are three basins (Ponds $1 \mathrm{a}, \mathrm{b}$ and $\mathrm{c}$ ) that will receive dredgings and will ultimately drain into Pond 1 . At the eastern edge of Cedar Swamp is the Swimming Hole, this small pond receives the drainage from Cedar Swamp including Zones 7,8 and 9, which then drains into the channelized section of Cedar Swamp Brook for transport to Upper Simmons Reservoir.

\section{Lakes}

Almy Reservoir and Upper Simmons Reservoir have shoreline along RIRRC property. The importance of these two water bodies is not that they abut RIRRC property, it is rather that they receive most of the drainage from RIRRC property. Almy Reservoir receives the drainage from a small portion of the Zone 1, most of Zone 3, much of Zone 4 and all of Zone 5. Upper Simmons Reservoir receives most of the drainage from RIRRC property via Cedar Swamp Brook. The importance of Upper and Lower Simmons Reservoirs is underscored by the consent agreement leading to the restoration operations for the reservoirs and the associated wetlands.

\section{Description of Wetlands in Study Zones}

\section{A. ZONE 1}

There are about 8.5 acres of wetlands within Zone 1 of which about eight were delineated in the "OU2 Study". Most of these are the eastern most part of Cedar Swamp to the north, south and west of the Swimming Hole. Along Shun Pike are five small seasonal wetlands that range from 1800 square feet to 15,000 square feet $(0.35$ acres) that were identified in the "OU2 Study". According to the "OU2 Study" the wetlands of Cedar Swamp receive no direct landfill runoff. The runoff from the north, west and south faces of the landfill eventually makes its way into Quarry Stream and the channelized section of Cedar Swamp Brook. Also identified in 
aerial photographs and during preliminary field observation are areas of wetlands in various stages of development along Cedar Swamp Brook to the west and south of the landfill in and around Ponds 1,2 and 3, and in depressions throughout the zone. The developing wetlands are typified by emergent vegetation such as Phragmites (Reed Grass) and Cattails.

\section{B. ZONE 3}

Within Zone 3 there are about 12.5 acres of wetlands. There are two areas of wetlands in the zone and both are associated with the Almy Reservoir watershed. Out of this approximately 4.25 acres were delineated that extend across the northwestern part of the zone from south of Central Pike in a northeasterly direction to Almy Reservoir. With the exception of one small area this wetland was flagged and surveyed by GZA in the "OU2 Study". The second is a wetland of about 8.5 acres with 5.5 acres lying within RIRRC property, that extends southward from Almy Reservoir under Central Pike towards Macera Circle. The northwestern wetland is essentially a seasonally wet forested swamp as is the part of the eastern wetland that is north of Central Pike. South of Central Pike the wetland consists of wet meadow emergents, shrub marsh and areas of open water with floating plants. This area receives most of the surface runoff from Zone 3 .

\section{ZONE 4}

Within Zone 4 RIGIS coverage indicates the existence of about two and a quarter acres of wetlands that the "OU2 Study" did not recognize. The largest of these covers about two acres. This area extends northward from Pond 4 to and then eastward along Central Pike. The other is a wetland of about 16,000 square feet $(.36$ acres) in the southwest comer that it shares with Zone 6. Preliminary field observation indicates that this area is dominated by upland vegetation with stands of Red Maple in low lying areas. This along with the lack of wetland soils and larger areas of wetland vegetation may indicate that while this area is not a wetland, it may be that it is instead an area prone to flooding. Accurate determination and verification of any wetlands in Zone 4 requires a survey comparable to the one by GZA for the "OU2 Study".

\section{ZONE 5}

A wetland of approximately 12 acres extends northward and then eastward from Central Pike that covers much of the interior of Zone 5. The "OU2 Study" and RIGIS wetland coverage both recognize the existence of this wetland, but only about 2.5 acres were flagged and surveyed as part of the "OU2 Study".

\section{E. ZONE 6}

There are five separate wetland areas within Zone 6 totaling about 3.5 acres. Three of these are small wetlands ranging from 16,000 square feet $(0.36$ acres) to about one half acre. Only one of these areas was identified by both RIGIS and the aerial survey used by GZA for the "OU2 Study". The other two wetlands in the west of the zone are part of the edge of Cedar Swamp. 


\section{F. ZONE 7}

Within Zone 7 are approximately 7.5 acres of wetlands delineated by GZA for the "OU2 Study". Of this, about 4.5 acres are part of the Cedar Swamp system. While this is a rather small area of wetlands it needs to be considered in the context as part of Cedar Swamp. This area also includes a large area of soils that are subject to a seasonally high water table. The wetlands in the southwestern portion is part of a drainage system that ultimately feeds into Cedar Swamp. One small wetland is not part of the Cedar Swamp system. This wetland lies within the Scituate Reservoir watershed. Whereas the total area of wetlands within Zone 7 is rather low, they isolate the uplands in the central part of the zone.

\section{G. ZONE 8}

The dominant feature in Zone 8 is the approximately 41.5 acres of wetlands that are a part of Cedar Swamp that were delineated in the "OU2 Study". This area includes persistent, seasonal and transitional wetland areas.

\section{H. ZONE 9}

Within Zone 9 are about 22 acres of wetlands. A November, 1995 study by GZA delineated approximately 16.4 acres of wetlands covering most of the eastern part of the zone. The remaining wetlands are recognized by RIGIS coverage and the aerial survey used by GZA along the western boundary and along Shun Pike.

These wetlands effectively isolate an area in the middle of the zone that is comprised of soils that are prone to a seasonally high water table. These wetlands drain northward towards Cedar Swamp. Accurate determination of wetlands along the western side of the zone will require a survey similar to that used by GZA to delineate the wetlands in the "OU2 Study" and for the eastern part of Zone 9.

\section{ZONE 10}

The OU2 study identified an area of about one half acre, while RIGIS coverage additionally identifies a narrow strip along the shore of Upper Simmons Reservoir. RIGIS wetlands and landcover coverage identifies wetlands a little more extensive than that in the "OU2 Study".

\section{SECTION 4. LANDCOVER}

\section{General information}

The "OU2 study" identified nine habitat/landcover types in the OU2 study area, based on "Degraaf and Rudis discussion of habitat cover types" (OU2 Study). Out of these cover types, six will be briefly discussed as applicable to the discussion of landcover within the 10 study zones. While the "OU2 Study" did not extend to

all of the area within the study zones, preliminary field observation indicates that these landcover types extend throughout the study zones. Accurate delineation of cover types will require an additional survey of areas not 
covered by the "OU2 Study". This would include all or parts of Zones 3, 5, 6, 7, 8 and 9. An inventory of flora and fauna found on RIRRC property is found in: Central Landfill Ecological Characterization Operable Unit 2, Remedial Investigation - Task 2, Johnston, Rhode Island.

\section{Size Groups}

The landcover type is based on the type and size of the dominant vegetation. A more complete description of the vegetation in the dominant plant communities is found in the OU2 Study, Section 5.00. A description of the tree sizes used in the classification system are as follows in Table 4.5.

Table 4.5 Tree Size Groups

\begin{tabular}{ll}
\hline \multicolumn{1}{c}{ Tree Group } & \multicolumn{1}{c}{ DBH* $^{*}$} \\
\hline Sapling & $1-4 "$ \\
Pole Timber & $4-12 "$ \\
Saw Timber & $12+"$ \\
\hline Note. "DBH is diameter breast height
\end{tabular}

\section{Landcover Types}

\section{RED OAK SAPLING/POLE FOREST}

The predominant upland forest cover in the OU2 study area consists of Red Oak Sapling/Pole (Upland Forest) cover with the bulk of the trees in these two size groups. This landcover type is found on upland areas and slopes to steep to retain sufficient soil moisture to support "wetland to upland transitional landcover". Within the OU2 study area are distinct variations within the cover type, with the differences being canopy density and the makeup of the understory and groundplain vegetation.

\section{RED MAPLE SAPLING/POLE FOREST}

The Red Maple Sapling/Pole (Swamp Forest) cover is primarily limited to the wettest portions of the OU2 study areas forested wetlands. Red Maple is the dominant Canopy species with greater variety and density of vegetation found among the understory and groundcover plants than within forested upland areas.

\section{WHITE PINE, RED OAK, RED MAPLE SAPLING/POLE FOREST}

This landcover type is found primarily in the drier areas of forested wetlands and within delineated wetland boundaries retaining sufficient soil moisture to support it as a "Transitional Forest" landcover type between wetland forest and upland forest. There are variations within this landcover as a result of past clearing of forest cover. The landcover type varies primarily with regards to the density of the canopy and diversity within the understory and groundcover.

\section{UPLAND FIELD (grasses and forbs)}

Seeded "Upland Field" cover is primarily a seeded mix found in areas of the closed Phase I area of the landfill, borrow areas and other cleared areas within the landfill and operations areas that have been disturbed and are 
not currently in active use. Within these areas that have been inactive longest, shrubs and small trees have become established eventually leading the way for successional reforestation.

\section{SHALLOW MARSH}

"Shallow Marsh" is found in limited areas within the study zones. They are primarily limited to cove edges along Almy Reservoir, the wetland in Zone 3 and in areas seasonally flooded up to one foot in depth or that are persistently wet, particularly along the perimeters of Ponds 1, 2, 3 and 4, drainage ways, small depressions and along Cedar Swamp Brook in Zone 1. This landcover type is dominated by a few emergent vegetation types such as Reed Grass (Phragmites) and cattails.

\section{SHRUB SWAMP}

Shrub swamp is another landcover type of limited area and locations within the study zones. Preliminary field observation shows that within the wetland south of Central Pike in Zone 3 are areas of what may be classified as shrub swamp within the same wetland that also exhibits marsh species. A shrub swamp is dominated by woody shrubs in soils that are seasonally flooded up to 1 foot.

\section{Description of Landcover in Study Zones}

The discussion of landcover types for the Study Zones will be modified from the more specific description of types found on RIRRC property. This is because of the incomplete information regarding the extent of landcover types for all of the RIRRC property. The estimated area of each landcover type is based on the "OU2 Study", extent of wetlands coverage from both the"OU2 Study" and RIGIS coverage, RIGIS landcover and preliminary field observation. The landcover types that are broadly identified and discussed are: Upland Forest; Wetlands which combines Swamp Forest and Transitional Forest; Marsh combines Marsh and Shrub Swamp; Grass and Forbs which are non-grass herbaceous plants, this cover includes the areas of vegetative cover that over operational areas that are either not used or of sufficiently low intensity to allow successful establishment. An added category is related to "Human Activities" which are areas that include active operations, roads, parking areas, buildings, commercial recycling which result in maintained vegetative cover, poor cover or surfaces impervious or reduced permeability and residential areas. The extent of each category of landcover is shown on Map 4.4.

\section{A. ZONE 1}

Zone $\mathrm{I}$ is dominated by two landcover types. The first of these is approximately 180 acres of Upland Field which has been seeded throughout most disturbed areas of the zone. The second of these is approximately 42 acres of Upland Forest. This cover type occurs along most of the zone edges, particularly in along the western edge towards Cedar Swamp and along Shun Pike. Within Zone 1 are areas of Swamp Forest and Transitional Forest that are associated with Cedar Swamp which cover about 7.5 acres. Also within Zone 1 are 


\section{Map 4.4 Landcover}

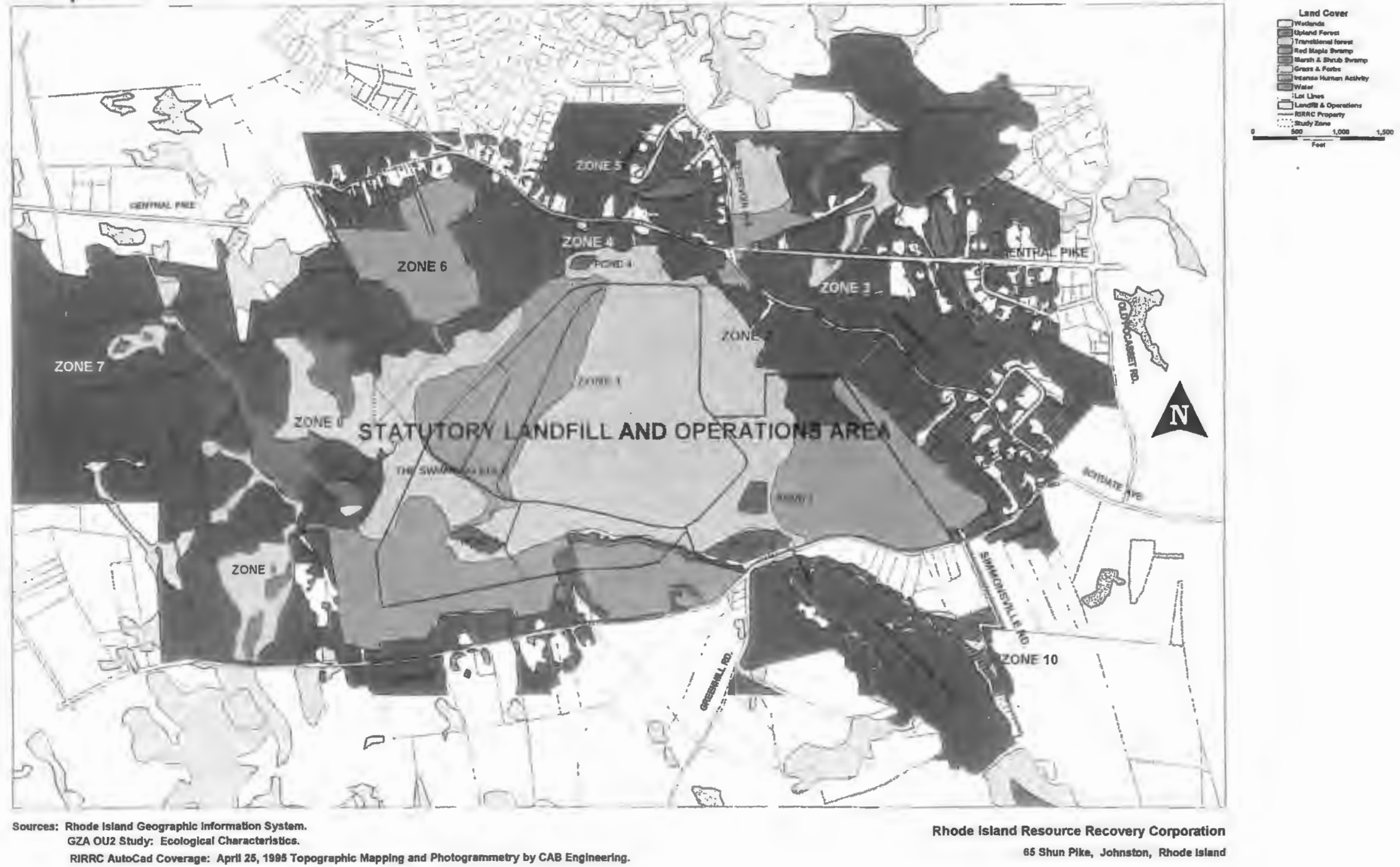


approximately 192 acres of land that is subject to intense human activity. These include activities that are associated with ongoing landfill and recycling operations. Associated with Ponds 1, 2 and 3, some drainage ways and Cedar Swamp Brook are areas of emergent vegetation associated with developing marshes and the transition from deep water habitat (usually greater than six feet in depth) to terrestrial habitat.

\section{B. ZONE 2}

Two surveyed landcover types are recognized as present within Zone 2. The first of these is approximately 20.5 acres of Upland Field which occurs in the western portion of the zone adjacent to past and present landfill and operations activities. The second is approximately 15.5 acres of Upland Forest in the eastern portion of the zone in areas of steeper slopes and surface rock.

\section{ZONE 3}

Only the most eastern portion of Zone 3 was surveyed in the "OU2 Study". Within the surveyed areas four basic landcover types were identified. The dominant type of landcover is Upland Forest which covers about 124 acres, Swamp and Transitional Forest combine to cover approximately 10.5 acres. Additionally associated with the most eastern wetlands within the zone there exists 2.8 acres of mixed Marsh and Shrub Swamp. Preliminary field observation indicates that these landcover types extend through the parts of the zone not covered by the "OU2 Study". Much of Zone 3 north of Central Pike is covered by Swamp and Transitional forest. This area lies within the northwest part of the zone and along Almy Reservoir. The area of human activity that is related to residential lots and roads covers about 31.5 acres.

\section{ZONE 4}

Only the most eastern two thirds of Zone 4 were included in the "OU2 Study". The study identified two landcover types. In the southern part of the zone adjacent to the landfill is an area of approximately 9.7 acres of Upland Field landcover. The northern portion of the zone is covered with approximately 20.4 acres of Upland Forest used as a visual buffer. The non-surveyed area primarily consists of upland forest with pockets of Red Maple forest in low lying areas. Upon preliminary field observation, the areas identified by RIGIS coverage as wetlands are dominated by Upland Forest with pockets of Red Maple stands in low lying areas. In addition there are two areas of intense human activities that cover about 3.4 acres.

\section{E. ZONE 5}

Only about one fourth of Zone 5 was covered in the "OU2 Study". This area is located in the southeast comer of the zone. Two primary Landcover types were identified in this area. They include Upland Forest and Swamp Forest in the surveyed wetlands. Preliminary investigation shows that these landcover types dominate the non-surveyed Upland and wetland areas. Overall, there is approximately 37 acres of Upland Forest cover 
in the zone. Swamp and Transitional Forest covers about another 11.7 acres with about 9 acres covered by residential lots property and roads.

\section{F. ZONE 6}

Zone 6 contains very little area that was covered in the "OU2 Study". This area is in the lower portion of the zone adjacent to Zone 1 and 8 in areas of past landfill and extraction activities. Identified landcover includes Upland Forest and Upland Field. In the zone approximately 48 acres are covered by Upland Forest and about 4.5 acres upland field. Scattered through out the zone are pockets of Swamp and Transitional forest that may cover about 3.5 acres. A major portion of the zone is covered by areas of human activity that is used for landfill construction staging operations. Out of this about 40 acres, 35.5 is used for staging operations and is relatively devoid of landcover.

\section{G. ZONE 7}

Zone 7 lies completely outside the OU2 study area for landcover. Based on preliminary field survey, aerial photography and RIGIS coverage the zone is dominated by Upland Forest with areas of Swamp and Transitional Forest in the eastern portion of the zone that is part of Cedar Swamp and in the extreme southwest. Upland forest covers about 37 acres with about 10 acres covered with Swamp and Transitional cover.

\section{H. ZONE 8}

The dominant Landcover types in Zone 8 are Swamp and Transitional Forest associated with Cedar Swamp. Within the upland areas in Cedar Swamp and bordering it is Upland Forest. About 45 acres of Zone 8 are covered with Swamp and Transitional Forest, with about 35 acres covered in Upland Forest.

\section{ZONE 9}

Zone 9 was not included in the "OU2 Study", but based on adjacent surveyed areas, aerial photography, RIGIS coverage and preliminary field observation, Upland, Swamp and Transitional Forests are the primary landcover types. Based on estimated range of cover types about 18.5 acres are Upland Forest with about 22 acres covered by Swamp and Transitional Forest.

\section{J. ZONE 10}

The only part of Zone 10 that was surveyed in the "OU2 Study" was a narrow strip along Upper Simmons Reservoir. Along this stretch of shoreline upland Red Oak Forest was the only landcover type identified. RIGIS coverage identifies wetland vegetation in the northern end and a narrow belt along Upper Simmons Reservoir. The primary landcover type along the slopes of Zone 10 is upland forest and the remains of landscaping trees from the residential units that had stood on some of the lots. 


\section{SECTION 5. ZONING AND STRUCTURES}

\section{General Information}

There are three Town of Johnston zoning designations that apply to the property owned by RIRRC and to private property in the immediate vicinity of the Central Landfill. These zoning classifications are "R-40" Residential, "I" Industrial and "I-L" Industrial Districts and are shown in Map 4.5. The following section provides a brief description of applicable zoning from the Johnston, Rhode Island Zoning Ordinance:

Ordinance \# 941, as Amended December 14, 1994, and in Table 4.6 lists the zoning that presently exists within and adjacent to each zone.

Table 4.6 Zoning within and adjacent to Study Zones

\begin{tabular}{lccc}
\hline Zone & R-40 & I & I-L \\
\hline Zone 1. Within & $\mathrm{X}$ & $\mathrm{X}$ & - \\
Adjacent property & $\mathrm{X}$ & $\mathrm{X}$ & $\mathrm{X}$ \\
Zone 2. Within & - & $\mathrm{X}$ & - \\
Adjacent property & - & - & - \\
Zone 3. Within & $\mathrm{X}$ & $\mathrm{X}$ & $\mathrm{X}$ \\
Adjacent property & $\mathrm{X}$ & $\mathrm{X}$ & - \\
Zone 4. Within & $\mathrm{X}$ & $\mathrm{X}$ & - \\
Adjacent property & - & - & - \\
Zone 5. Within & $\mathrm{X}$ & - & - \\
Adjacent property & $\mathrm{X}$ & - & - \\
Zone 6. Within & $\mathrm{X}$ & - & - \\
Adjacent property & $\mathrm{X}$ & - & - \\
Zone 7. Within & - & $\mathrm{X}$ & - \\
Adjacent property & $\mathrm{X}$ & - & $\mathrm{X}$ \\
Zone 8. Within & - & $\mathrm{X}$ & - \\
Adjacent property & $\mathrm{X}$ & - & $\mathrm{X}$ \\
Zone 9. Within & - & & $\mathrm{X}$ \\
Adjacent property & - & - & $\mathrm{X}$ \\
Zone 10. Within & $\mathrm{X}$ & $\mathrm{X}$ & - \\
Adjacent property & $\mathrm{X}$ & $\mathrm{X}$ & - \\
\hline
\end{tabular}

\section{Description of Zoning Districts}

Three Johnston Zoning Districts are represented within RIRRC property and on adjacent parcels. The first of these is the Residential, "R-40" district. This district covers a large portion of the Town into which urban-type development should expand as the need arises. This district is characterized by a commingling of open land interspersed with residential uses. The second zoning district is Industrial, "I". This district is comprised of certain land situated as to be suitable for industrial development. The purpose of this district is to permit the normal operation of a large number of industries, subject only to those regulations needed to control congestion and to protect nearby residential and business districts. The third of these is the Light Industrial "I-L". This district is composed of certain land so situated as to be suitable for light industrial development. The purpose of this district is to permit the operation of a limited number of industrial uses and heavy business uses that will be compatible with nearby residential and business districts. 


\section{Map 4.5 Town of Johnston Zoning}

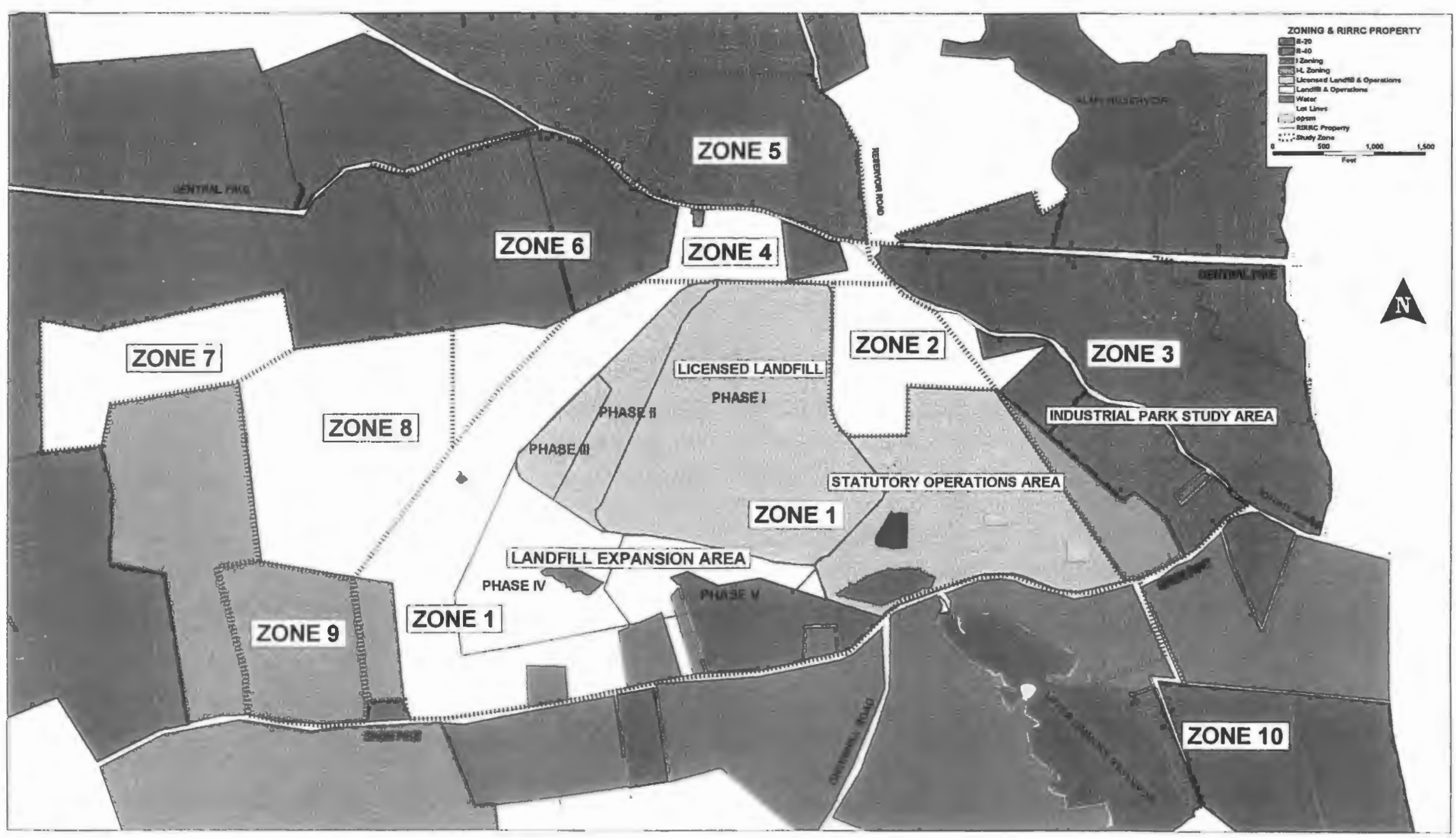

Sources: Rhode Island Geographic Information Syatem.

RIRRC AutoCad Coverage: April 2s, 1995. Topographlc Mapping and Photogrammetry by CAB Engineering.

Rhode Island Resource Recovery Corporation Town of Johnston Zoning. 65 Shun Plke, Johnston, Rhode island 


\section{Structures in Study Zones}

The primary concern with this section are those structures that are located on the properties recently purchased by RIRRC. The property that RIRRC has purchased since the passage of Sections 23-19-34 and 23-19-35 of the R.I.G.L. in 1989, include several properties with structures located on them. Those residential structures that were within the statutory 1000 -foot buffer were demolished. Most of the remaining residential structures owned by RIRRC are currently rented out. A few structures are abandoned, or are used for storage by RIRRC. This section involves a discussion of the properties with structures owned by RIRRC and those still owned by private citizens that lie within the 10 Study Zones. Included with this discussion are Tables 4.6 through 4.9 showing which properties have structures on them, the status and the zoning of the individual parcels. The following discussion concerns the Study Zones identified as having lots with structures located on them, the Study Zones included in this discussion are Zones 1, 3,5 and 6. Study Zones without properties acquired in the land acquisition are Zones 2, 4, 7, 8 and 9. Particular emphasis is placed on those lots with structures purchased under Sections 23-19-34 and 35 of the R.I.G.L.

\section{A. ZONE 1}

There are four properties along Shun Pike that have structures on them, of these only one lot has a residential unit located on it. The remaining lots have structures on them that are used for storage by RIRRC, or are currently abandoned. The following table is a listing of lots with structures that are within Zone 1 . In addition to the structures on the land acquisition properties there are several structures on the initial Central Landfill property. These are the Engineering and Operations Building, the Materials Recycling Facility, the Scale House, within the Commercial Recycling Area, the Gas Recovery Facility, the Sewerage Pump Station, the Guard Shack and the Leachate Pretreatment Facility.

Table 4.7 Zone 1 Lots with Structures

\begin{tabular}{llll}
\hline Plat/Lot & \multicolumn{1}{c}{ Address } & \multicolumn{1}{c}{$\begin{array}{c}\text { Status } \\
\text { rental and non-rental lots }\end{array}$} & Zoning \\
\hline $43 / 165$ & 129 Shun Pike & Abandoned & I \\
$43 / 154$ & 93 Shun Pike & Rental. residential & I \\
$43 / 036$ & 77 Shun Pike & Storage & I \\
$42 / 567$ & 75 Shun Pike & Storage & R-40 \\
\hline
\end{tabular}

\section{B. ZONE 3}

Zone 3 is a residential zone with structures along Shun Pike, Scituate Avenue, Macera Circle, Central Pike and Apple Tree Lane. Within Zone 3 there are 31 lots with residential structures. 27 of these are RIRRC properties. The following table is of lots with structures that are located within Zone 3. 
Table 4.8 Zone 3 Lots with structures

\begin{tabular}{|c|c|c|c|}
\hline Plat/Lot & Address & $\begin{array}{c}\text { Status } \\
\text { rental and non-rental lots }\end{array}$ & Zoning \\
\hline $43 / 127$ & 3 Shun Pike & non-RIRRC & $R-40$ \\
\hline $43 / 584$ & 295 Scituate Ave & rental & $\mathrm{R}-40$ \\
\hline $43 / 263$ & 297 Scituate Ave. & rental & $\mathrm{R}-40$ \\
\hline $43 / 278$ & 298 Scituate Ave & rental & $\mathrm{R}-40$ \\
\hline $43 / 261$ & 301 Scituate Ave & rental & $R-10$ \\
\hline $43 / 121$ & 306 Scituate Ave & rental & $R-40$ \\
\hline $43 / 119$ & 310 Scituate Ave. & rental & $\mathrm{R}-40$ \\
\hline $43 / 152$ & 294 Scituate Ave & non-RIRRC & $R-40$ \\
\hline $43 / 412$ & 2 Macera Circle & rental & $R-40$ \\
\hline $43 / 411$ & 3 Macera Circle & rental & $\mathrm{R}-40$ \\
\hline $43 / 413$ & 4 Macera Circle & rental & $\mathrm{R}-40$ \\
\hline $43 / 409$ & 7 Macera Circle & rental & $\mathrm{R}-40$ \\
\hline $43 / 408$ & 9 Macera Circle & rental & $\mathrm{R}-40$ \\
\hline $43 / 407$ & 11 Macera Circle & rental & $R-40$ \\
\hline $43 / 406$ & 15 Macera Circle & rental & $\mathrm{R}-40$ \\
\hline $43 / 405$ & 17 Macera Circle & rental & $\mathrm{R}-40$ \\
\hline $43 / 404$ & 19 Macera Circle & rental & $\mathrm{R}-40$ \\
\hline $43 / 212$ & 9 Apple Tree Lane & rental & $R-10$ \\
\hline $43 / 201$ & 12 Apple Tree Lane & rental & $\mathrm{R}-40$ \\
\hline $43 / 202$ & 14 Apple Tree Lane & rental & $R-40$ \\
\hline $43 / 341$ & 16 Apple Tree Lane & rental & $\mathrm{R}-40$ \\
\hline $43 / 338$ & 18 Apple Tree Lane & rental & $\mathrm{R}-10$ \\
\hline $43 / 214$ & 735 Central Ave. & rental & $\mathrm{R}-40$ \\
\hline $43 / 514$ & $7351 / 2$ Central Ave. & rental & $\mathrm{R}-40$ \\
\hline 43/008. & 739 Central Ave & rental & $\mathrm{R}-40$ \\
\hline $43 / 019$ & 751 Central Ave. & rental & $\mathrm{R}-40$ \\
\hline $43 / 277$ & 753 Central Ave. & rental & $\mathrm{R}-40$ \\
\hline $43 / 007$ & 738 Central Ave. & non-rental & $\mathrm{R}-40$ \\
\hline $43 / 309$ & 748 Central Ave. & rental & $\mathrm{R}-40$ \\
\hline $43 / 276$ & 754 Central Ave & rental & $\mathrm{R}-40$ \\
\hline $43 / 275$ & 737 Central Ave. & non-RIRRC & $\mathrm{R}-40$ \\
\hline $43 / 276$ & 740 Central Ave. & non-RIRRC & $\mathrm{R}-40$ \\
\hline
\end{tabular}

\section{ZONE 5}

Zone 5 is a residential zone with 10 lots that have residential units on them of which 8 are RIRRC properties.

The lots are located along Alaina Drive, Reservoir Avenue and Central Avenue. The following table is of lots with structures that are within Zone 5.

Table 4.9 Zone 5 Lots with Structures

\begin{tabular}{llll}
\hline Plat/Lot & \multicolumn{2}{c}{ Address } & \multicolumn{1}{c}{$\begin{array}{c}\text { Status } \\
\text { rental and non-rental lots }\end{array}$} \\
\hline $43 / 532$ & 95 Reservoir Ave. & rental & Zoning \\
$43 / 534$ & 101 Reservoir Ave. & rental & R-40 \\
$43 / 535$ & 103 Reservoir Ave. & rental & R-40 \\
$43 / 537$ & 107 Reservoir Ave & rental & R-40 \\
$43 / 550$ & 97 Reservoir Ave. & non-RIRRC & R-40 \\
$43 / 536$ & 105 Reservoir Ave. & non-RIRRC & R-40 \\
$43 / 566$ & 2 Alaina Drive & rental & R-40 \\
$43 / 556$ & 7 Alaina Drive & rental & R-40 \\
$43 / 557$ & 9 Alaina Drive & rental & R-40 \\
$43 / 532$ & 14 Alaina Drive & rental & R-40 \\
$43 / 244$ & 1062 Central Ave. & rental & R-40 \\
\hline
\end{tabular}




\section{ZONE 6}

Included in the Zone 6 inventory of lots with structures are those within Zone 6 and the single unit on the north side of Central Avenue. Within the zone are 13 residential lots with structures on them of which only five are owned by RIRRC. The following table is of lots with structures that are within Zone 6 .

Table 4.10 Zone 6 Lots with Structures

\begin{tabular}{llll}
\hline PlatLot & \multicolumn{1}{c}{ Address } & \multicolumn{1}{c}{$\begin{array}{c}\text { Status } \\
\text { rental and non-rental lots }\end{array}$} & Zoning \\
\hline $43 / 511$ & 1076 Central Pike & rental & R-40 \\
$43 / 155$ & 1112 Central Pike & rental & R-40 \\
$43 / 158$ & 1114 Central Pike & rental & R-40 \\
$43 / 164$ & 1114 Central Pike & non-rental & R-40 \\
$43 / 153$ & 1150 Central Pike & abandoned & R-40 \\
43 N/A & N/A Central Pike & non-RIRRC & R-40 \\
$43 / 180$ & 1130 Central Pike & non-RIRRC & R-40 \\
$43 / 174$ & N/A Central Pike & non-RIRRC & R-40 \\
$43 / 175$ & 1134 Central Pike & non-RIRRC & R-40 \\
$43 / 161$ & I140 Central Pike & non-RIRRC & R-40 \\
$43 / 195$ & N/A Central Pike & non-RIRRC & R-40 \\
$43 / 178$ & N/A Central Pike & non-RIRRC & R-40 \\
\hline
\end{tabular}

\section{E. ZONE 10}

Zone 10 is the area of land purchased along Simmons Lake Drive. The properties in the zone included several that had residential structures on them. These structures were demolished in accordance with Section 23-1934.1 of the R.I.G.L.

\section{SECTION 6. CONSTRAINTS AND OPPORTUNITIES}

\section{General Information}

This section looks at the factors that influence land use decisions from Sections 1 through 5 as they apply to land use policy for RIRRC property at the Central Landfill. This section discusses the importance, affect and relative level of constraint associated with the previously discussed factors. This discussion begins by discussing the three broad categories of constraints and the elements of each category analyzed : environmental and physical; land use both on RIRRC property and nearby; and, legal constraints.

\section{Environmental and Physical Constraints}

Environmental and physical factors are those factors that most directly influence development. They exert influence by allowing certain intensities of development to occur. and by affecting the cost of development related to the ease or difficulty in overcoming the associated constraints.

Soil constraints are related to both environmental and financial factors. Hydric soils and soils that have Seasonal High Water Tables are associated with wetlands and areas that are prone to flooding. These areas have demonstrated values associated to the management of drainage and flooding, the settling of suspended 
sediments, filtration of pollutants, the absorption of chemicals and excess nutrients, and wildlife habitat. It is for these and other demonstrated values that wetlands are protected at the state and federal levels.

Soils found on slopes tend to be thin and shallow with bedrock near the surface. Erosion potential and cost of development increases with the slope by increasing the measures that must be undertaken for construction and restricting site layout options. Related to slopes, is the value that vegetation plays in the control of erosion and the management of drainage by retaining thin soils and reducing the rate and volume of surface flow of storm water runoff minimizing impact to the surface water bodies.

Surface water consists of lakes, ponds and streams. These water bodies play roles in the management of drainage by either receiving drainage, or channeling runoff and controlling downstream sedimentation. It is the environmental and societal roles of surface water, whether public water supply, irrigation, or recreational, that justify their protection by RIDEM. The value of surface water places a need for development that will control drainage in a manner that not only preserves the existing water quality, but improves water quality as evidenced by the plan to dredge and restore the water quality and wetlands of Upper and Lower Simmons Reservoirs.

Surface boulders and bedrock constrain development in large part by increasing the costs of development associated with the excavation of rock. The shallow soils that are associated with surface bedrock limit the development of road beds, foundations, sewer and water lines, and the burial of cables. Although, surface boulders require the excavation of boulders, the soils may otherwise be suitable for development.

Physical factors concern the availability and quality of access, utilities and public services. The constraints associated with these factors involve primarily the effect they have on the costs of development related to supplying, or improving these facilities.

\section{Land Use Constraints}

The second set of factors that constraint the use RIRRC property are those related to current and future land use. This not only refers to current and planned uses of RIRRC property, but also property located near the landfill and also along roads that access the Central Landfill. The estimated 20 to 25 year life-span of the Central Landfill makes any alternative use of land located within the 600-foot DEM buffer a long-term planning and development option. Land use decisions are in turn affected by nearby development that increases the demand for the services that the development RIRRC require. Perhaps more important than Central Landfill operations is increased development (particularly residential) in the vicinity of the Central Landfill that results in the number of residents and business owners who will perceive themselves as directly affected by RIRRC land use decisions. Map 4.6 identifies land use in the study area. 


\section{Map 4.6 Area Land Use}

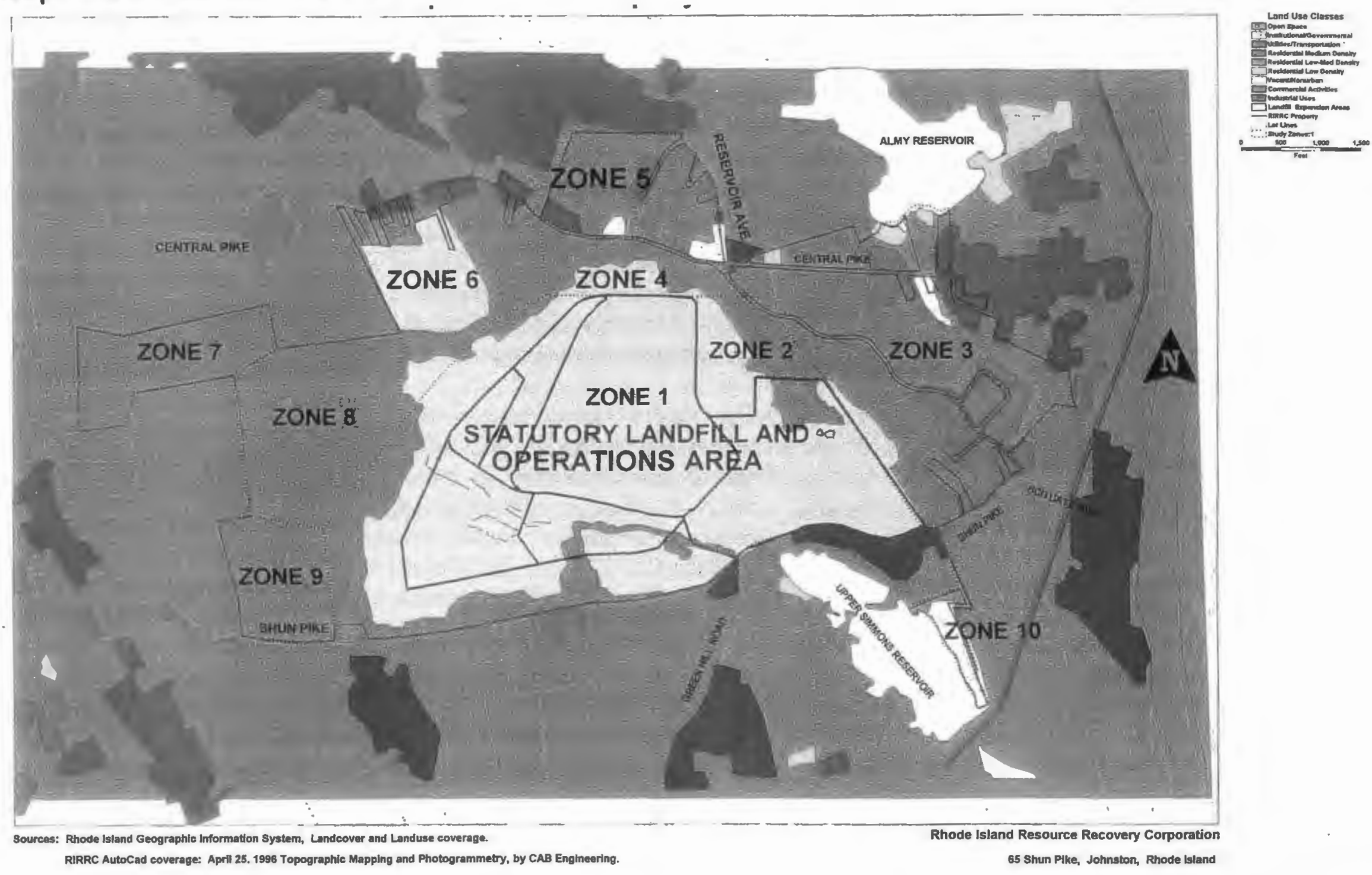




\section{Legal Constraints}

Three basic categories of legal constraints to development were used in the analysis of suitability for development. The first set of these constraints related to the regulatory powers of RIDEM particularly as related to the Freshwater Wetlands Act which controls the development in and around wetlands by establishing 50, 100, or 200 foot buffer zones depending upon the type and size of wetlands, streams and waterbodies. RIDEM also has a regulatory role pertaining to the 600 -foot Landfill Development Restriction found in the "Rules and Regulations for Solid Waste Management Facilities". Both sets of regulations receive their authority from Statute. The Freshwater Wetlands Act's authority to regulate is based in the March 1994 revision as pursuant to Chapters 2-1-20.1, 42-17.1, 42-17.6 and 42-35 of the R.I.G.L., 1956, as amended. The Rules and Regulations for Solid Waste Management Facilities (Regulation DEM-DAHM-SW03-92) authority are based on Section 42-35 pursuant to Sections 23-18.9 and 23-63 of R.I.G.L. of 1956, as amended.

The second set of legal constraints are those related to the purchase and regulation of land use within the 1000foot buffer and the 2000-foot development restriction are from Sections 23-19-34, 34.1, 35, and 35.1 of the R.I.G.L. The third category of legal constraints are those imposed by the Johnston Zoning Ordinance. These are regulations regarding the allowed types and densities of development on RIRRC property and nearby privately owned property.

\section{Degree of Constraints}

In order to determine what land is most suitable for development or most constrained it is necessary to use a system that assesses a constraint level that helps to explain the suitability for development of a piece of land. Standard methodologies tend to use three levels of constraints such as those used in soil suitability analysis. Typical constraint levels are: slight, moderate, and severe. In order to more effectively determine the relative . development suitability levels two intermediate categories were added. These additional categories are: "slight to moderate" constraints, and "moderate to severe" constraints.

\section{Description of Zone Constraints}

This section discusses the constraints specific to each zone. Table 4.11 provides an inventory of factors and constraints that influence land use decisions used in this analysis. There are some areas of overlap between restrictions. An example of this is that RIDEM wetland buffer areas include wetlands within the total area affected by the wetland buffer. 
Table 4.11 Study Factors and Constraints*

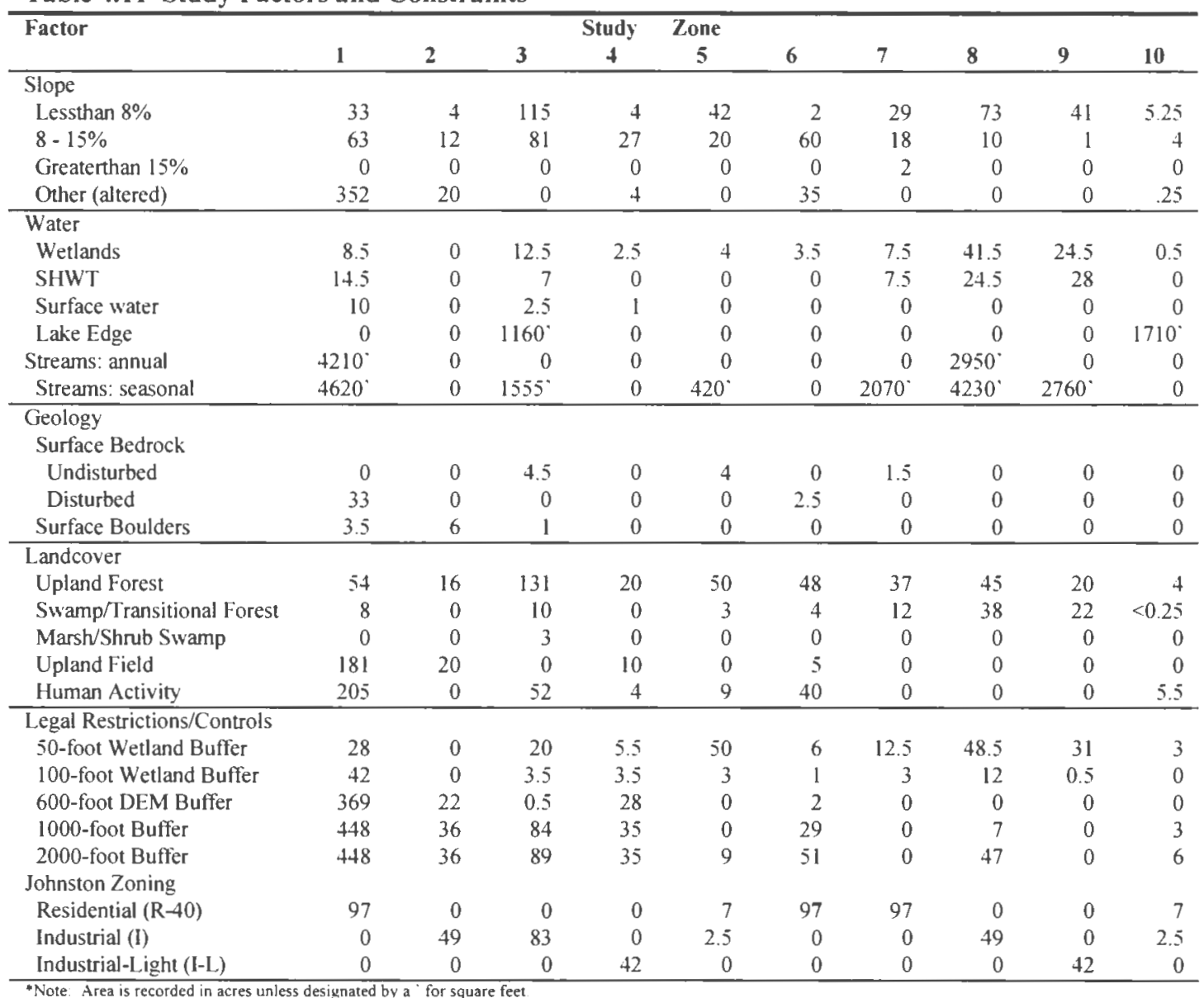

\section{A. ZONE 1}

Environmental and physical constraints include slopes up to 15 percent and greater along the slopes north of

Shun Pike where gravel has been extracted. Development alternatives are severely constrained by current and future landfill operations, but these operations themselves are constrained by environmental, physical and legal factors. Wetlands that are part of Cedar Swamp in the area of the Swimming Hole and the consent agreement prevent the westward and northward expansion of landfill activities. Scattered small wetlands along Shun Pike require permission to alter prior to the excavation of gravel southward toward Shun Pike. A cemetery in the southwest part of Zone 1 requires permission to move it prior to expansion of gravel extraction activities. The southwest borrow area has been excavated to or close to bedrock. Expansion of landfill activities southward beyond the planned and proposed Phase IV and V operations are constrained by the 600-foot DEM Landfill Development Restriction as is northward expansion. Eastward expansion into Zone 2 is currently prevented by the Hazardous Materials CERCLA site waiting for capping operations. 


\section{B. ZONE 2}

The primary constraints affecting alternative land uses for Zone 2 are related to landfill operations, regulatory and statutory limitations regarding the expansion of the Central Landfill and activities that may occur. Currently ongoing and future staging operations limit other uses. Areas of surface boulders "the Round Rocks" and slope constraints help to limit other uses. The extent of any eastward expansion will be constrained by the location, type and extent of development that occurs in Zone 3, and the required 600-foot DEM Landfill Development Restriction that is meant to protect adjacent properties from encroachment by landfill operations. All of Zone 2 falls within the 1000-foot Landfill Buffer and its associated development restrictions.

\section{ZONE 3}

Zone 3 is the largest block of properties that RIRRC was required to purchase as a result of Sections 23-19-34, 34.1, 35, and 35.1, of the R.I.G.L. The primary constraints to development alternatives are related to environmental factors. Chief among these are wetlands and their related wetland buffers required by DEM regulations. Additional severe constraints include areas of surface bedrock and some isolated slopes in excess of 15 percent. More moderate constraints include 8 to 15 percent slopes, soils with Seasonal High Water Tables and an extension of the "Round Rocks" deposits into the west central part of the zone. Legal constraints are those development restrictions provided by the 1000-foot Landfill Buffer in the extreme western part of the zone, the 2000-foot development restriction and those restrictions on use included in the Johnston Zoning Ordinance. Development of Zone 3 will mean limited use of the zone for landfill activities. chief among these are as a staging area for landfill operations, topsoil and gravel extraction.

In general Zone 3 is the Study Zone with the fewest constraints. According to RIGIS soils coverage approximately 115 of 196 acres are soil types with slopes less than 8 percent and the remaining soil types with slopes in the 8 to 15 percent range. The zone has direct access from multiple directions. Utilities are either present in Zone 3 or are present in the immediate area. Sections 23-19-34, 34.1, 35, and 35.1, of the R.I.G.L. restrict development to industrial uses. In general the land with the greatest overall constraints is in the northern part of the zone, where most of the adjacent residential development has occurred. Within the southern part of Zone 3 are areas of land previously cleared for residential development.

\section{ZONE 4}

Many of the constraints in Zone 4 are related to its use as a visual and physical buffer, and as part of the 600foot DEM Landfill Development Restriction. Constraints associated with landfill operations in the zone have to do with its role in the management of landfill runoff. The main environmental constraints are slopes in the 8 to 15 percent range with isolated areas exceeding 15 percent. In addition, there is the area of the zone that appears to be flood prone while not being classified as a wetland. 


\section{E. ZONE 5}

Zone 5 is another section of property that RIRRC purchased as a result of Sections 23-19-34, 34.1, 35, and 35.1, of the R.I.G.L. The constraint related to this was the establishment of the 1000 -foot landfill buffer that runs through the south part of the zone, and the 2000 -foot development restriction that prevents the use of

purchased property from being developed for residential purposes. Environmental constraints include areas of slopes in the 8 to 15 percent range and isolated slopes in excess of 15 percent, surface bedrock in the northwest and wetlands throughout the center of the zone. Additionally, Johnston zoning restricts the uses of the property, as does the residential zoning of neighboring properties. An area that may be classified with fewer constraints after more detailed analysis is the southeast comer of Zone 5. The isolation from the rest of Zone 5 and the nearby residential areas by the internal wetland may improve the feasibility for developing it in relation to any Industrial Park development in Zone 3.

\section{F. ZONE 6}

Zone 6 properties were also purchased by RIRRC in response to the passage of Sections 23-19-34, 34.1, 35, and 35.1, of the R.I.G.L. in 1989. While land use decisions are affected the statutory restrictions the restrictions are not the primary limitations to alternative land uses. The most important constraints are those related to environmental factors, and particularly current and planned land use. The suitability for development of portions in the eastern part of the zone is minimized by slopes of 8 to 15 percent, some greater than 15 percent and mall scattered wetland areas. This area also functions as the vegetative buffer as required as a part of the 600-foot DEM Landfill Development Buffer. The westem part which is the most developable part of the zone, but it is constrained by an indefinite future as a staging area for landfill construction materials. It is after this use when the statutory restrictions and Johnston zoning restrictions become a factor. With a defined end to its use as a staging area and a site specific evaluation this area of about 40 acres may prove to be the most developable area after Zone 3 .

\section{G. ZONE 7}

The constraints on development in Zone 7 are primarily environmental in nature. In particular are the limitations on development related to the wetlands within the zone. While the only about 7.5 out of 49 acres are wetlands the narrow nature of the zone combined with the linear extension of the wetlands into the center of the zone combine to decrease the overall suitability of development within Zone 7. Other environmental factors include an slopes in excess of 15 percent, and shallow bedrock along the western boundary. The small area of Zone 7 that lies within the Scituate Reservoir watershed places an additional constraint related to its proximity to the largest source of public water in Rhode Island. The part of the zone that is suitable for development is constrained by proximity to the watershed and by a lack of direct access by road and to utilities. 


\section{H. ZONE 8}

The suitability for development for Zone 8 is severely constrained by environmental factors. In general the zone is unsuitable for development, and would best be managed for conservation purposes. The overwhelming constraints are those related to the fact that about half of the 83 acres were delineated as wetlands by GZA in the OU2 Study with another fourth of the zone being subject to a Seasonally High Water Table. Slopes are generally less than 8 percent or in the 8 to 15 percent range with some of the wetland areas which are less than 3 percent. Areas that are generally considered suitable for development based on environmental factors are small, isolated and lack direct access to roads and utilities.

\section{ZONE 9}

The property that Zone 9 is part of was purchased and development is restricted under the conditions of Section 23-19-35, 35.1 of the R.I.G.L. The stipulations in Section 35.1 limit development to industrial uses. While, Zone 9 is of a size sufficient to support development and has direct access; the wetlands that cover most of the perimeter and the internal soils that are subject to a Seasonal High Water Table cover almost all of the zone.

\section{J. ZONE 10}

The property that comprises Zone 10 was purchased as a result of Sections $2319-34$ and 35 of R.I.G.L. and development is controlled by Section 34.1 and 35.1. The development restrictions and the 50 foot DEM wetlands buffer along Upper Simmons Reservoir are the main legal restrictions to development.

Environmental restrictions include wetlands in the north and slopes that are in the 8 to 15 percent. The slope in the southem portion of the zone is primarily in the 0 to -8 percent range, but because of the shallow lots and the development restrictions related to wetlands protection and the acquisition conditions.

\section{Land Suitable for Development}

Based on a method of overlaying of the various constraints related to the identified factors areas, five relative constraint levels were identified that run along a continuum that assists in identifying the areas considered most suitable for development. These five levels are: slight, slight to moderate, moderate, moderate to severe and severe constraints. Wetlands with their associated regulatory buffer, surface bedrock, and RIGIS identified slopes in excess of 15 percent were weighted so that they would be identified as least suitable for development. The stated level of suitability and constraints for other areas is intended as a planning guideline, with any final decisions on development requiring field surveys for verification and the development of an assessment regarding the lifespan of all landfill associated operations. Such an assessment will help to identify lands that must be used throughout the life of the landfill and those peripheral areas that may be free for development before then. The analysis presented here identifies at a broad level the relative levels of suitability for development based on current conditions and plans. This analysis is intended to be used as a 
guide to future land use decisions and should be updated as conditions change. Final determination of a sites suitability requires a specific detailed examination based along this analysis and future questions that cannot be anticipated.

Other future analysis should be included to make this a more complete plan and guide for the development of RIRRC property. Some areas for future analysis and inclusion include: 1. An analysis of utilities, roads and community services and their ability to absorb greater use demands. Some of this should be included in the Industrial Park Feasibility Study, and the information that is pertinent should be included within the RIRRC Land Use Plan. 2. An analysis and projection of growth patterns in the Town of Johnston and the implications that demographic and economic changes may have on RIRRC land use decisions. 3. The development of an inventory of RIRRC plans that include the identification of areas and lifespan for staging and other landfill related operations. 4. Estimates of the duration of planned gravel extraction, volume and lifespan. The above suggestions would assist in identifying areas that are more suitable for development and could assist in the development of a strategic plan that frees up land for development in an orderly incremental manner that would also consider post landfill possibilities.

\section{Summary}

Sixty percent of the land is severely constrained. Moderate to severely constrained land comprises $14 \%$ of total RIRRC property. Moderately constrained land makes up $12 \%$ of the total land. Land that is classified with "slight" and "slight to moderate" constraints respectively cover $6 \%$ and $8 \%$ of RIRRC property. See Table 4.12 for the amount of land within the study zones affected by each constraint level. Map 4.7 shows the development suitability levels for the RIRRC Central Landfill property.

Table 4.12 Land Area per Constraint Level per Study Zone

\begin{tabular}{|c|c|c|c|c|c|c|}
\hline $\begin{array}{l}\text { Study } \\
\text { Zone }\end{array}$ & Slight & Sl-Mod & Mod & Mlod-Sey & Severe & Area \\
\hline 1 & 0.0 & 0.0 & 6.0 & 57.0 & 385.0 & 448.0 \\
\hline 2 & 0.0 & 0.0 & 12.0 & 1.0 & 23.0 & 36.0 \\
\hline 3 & 80.5 & 66.5 & 13.0 & 0.0 & 36.0 & 196.0 \\
\hline 4 & 0.0 & 0.0 & 1.0 & 18.0 & 16.0 & 35.0 \\
\hline 5 & 0.0 & 0.0 & 26.0 & 11.0 & 25.0 & 62.0 \\
\hline 6 & 0.0 & 0.0 & 54.0 & 21.0 & 22.0 & 97.0 \\
\hline 7 & 0.0 & 0.0 & 11.0 & 21.0 & 17.0 & 49.0 \\
\hline 8 & 0.0 & 0.0 & 1.5 & 25.5 & 56.0 & 83.0 \\
\hline 9 & 0.0 & 0.0 & 0.5 & 9.5 & 32.0 & 42.0 \\
\hline 10 & 0.0 & 0.0 & 4.0 & 2.5 & 3.0 & 9.5 \\
\hline Area & 80.5 & 66.5 & 129.0 & 166.5 & 615.0 & 1057.5. \\
\hline
\end{tabular}

Most of the land with "slight", "slight-moderate" and "moderate" constraints to development are located in three zones. These zones are Zone 3 which is the Industrial Park Study Area, Zone 5, and Zone 6. Based on the criteria used Zone 3 is the only zone with land classified with "slight" ( 80.5 acres), and "slightmoderate" ( 66.5 acres). Zones 5 and 6 are the only zones with greater than 20 acres of moderately 
Map 4.7 Development Suitability

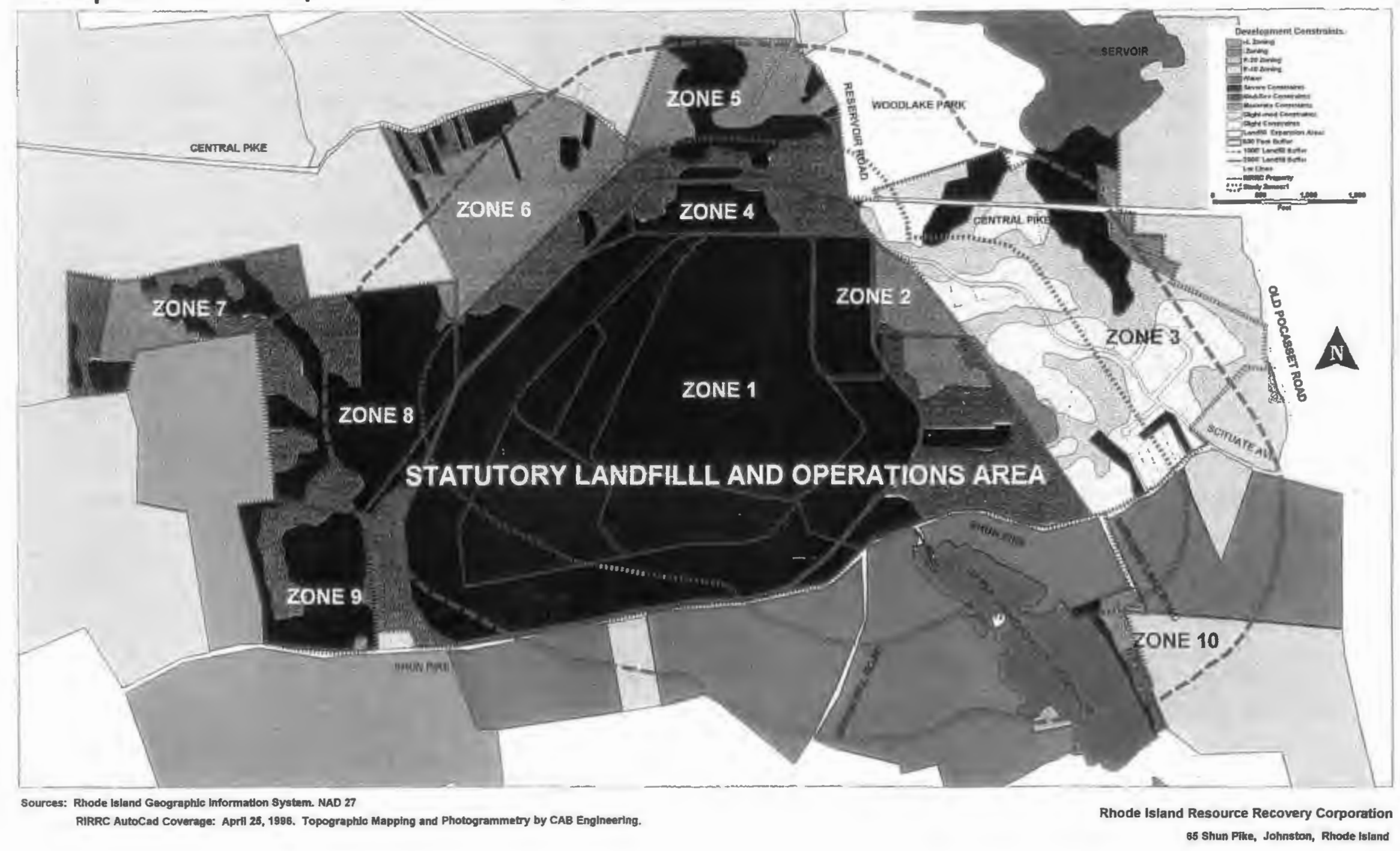


constrained land. A major factor reducing overall developability is that both zones are located within and require access through R-40 zoning districts. Additionally, these study zones are statutorily limited to industrial development through their inclusion within the 2000-foot buffer. Land within Zones 1, 2 and 4 are generally undevelopable because of their role in landfill operations. Even though there are 12 acres of moderately constrained land the zone is identified as a potential staging area for materials used in hazardous waste capping operations. Land within Zones 7, 8 and 9 are in general unsuitable for development because the presence of wetlands impose access constraints by isolating land that is otherwise suitable for development. 


\section{Chapter Five 1997 Land Use Suitability Analysis}

While this analysis covers the same land as the Study described in Chapter Four, it attempts to analyze the suitability for different land uses. Those land uses range from more intensive use and physical impacts to less intense uses. Even though the land purchased by RIRRC as a result of "Section 23-19-34 and Section 23-19-35 of the R.I.G.L." limits the use of that land to industrial uses land was also analyzed for suitability to support institutional, commercial and residential uses. There are three primary reasons for including this more discrete analysis of potential land use. The first is that in order to determine if to what degree the land analysis process can be streamlined it is helpful to analyze multiple land uses rather than taking one use out of the overall land use equation. The second is legal restrictions such as the statutory restriction on the property purchased by RIRRC, and proposed land use patterns as designated by zoning are more easily changed than those related to physical, environmental and accessibility constraints. The third reason is that in order to provide RIRRC options to build a long-term land use plan around the analysis needs to be comprehensive enough to view several potential uses over the life of the Central Landfill and beyond.

\section{ANALYSIS}

\section{Sieve 1 Analysis}

The analysis began with the entire 1057.5 acres owned by RIRRC located at the Rhode Island Central Landfill. This part of analysis ran through the first series of constraints which eliminated 680.3 acres from the analysis as unsuitable for development. This first screening eliminated sixty-four percent of the Central Landfill from further analysis. It is important to understand that the factors used are not mutually exclusive, but rather contain area of overlap. To counter this overlap as with any overlay analysis each factor is laid over the preceding factor to result in an aggregate area for total land eliminated as a result of the entire screening process at this level of the analysis. Factors used in the first sieve are hydric soil; slopes greater than 15 percent; surface bedrock; the "round rocks," an area of surface boulders on RIRRC property; area within legal wetland buffers; land within the Scituate Reservoir Watershed Protection District; land within the 600-foot DEM buffer around the licensed landfill; and, land used for landfill operations.

Map 5.1 and table 5.1 illustrate the results of the first level of screening. While each factor used in the first level of screening is a legitimate in that it renders land unsuitable for development for this study, not all add additional area to the total area classified as unsuitable for development. The area that lies within the Scituate Reservoir Watershed Protection Area, and the Round Rocks area that are unique to the Central Landfill fail to add any land to the total area, because through previous layers those areas were previously eliminated as unsuitable for development. 
Table 5.1 Sieve 1 Screening Results

\begin{tabular}{|c|c|c|c|c|c|c|c|c|c|c|c|}
\hline Zone & Area & $\begin{array}{l}\text { Hydric } \\
\text { Soils }\end{array}$ & $\begin{array}{l}\text { Slopes } \\
>15 \%\end{array}$ & $\begin{array}{l}\text { Surface } \\
\text { Bedrock }\end{array}$ & $\begin{array}{l}\text { Round } \\
\text { Rocks }\end{array}$ & $\begin{array}{l}\text { Wetland } \\
\text { Buffer }\end{array}$ & $\begin{array}{l}\text { Watershed } \\
\text { Protection }\end{array}$ & $\begin{array}{c}\text { 600-foot } \\
\text { DEM buffer }\end{array}$ & $\begin{array}{c}\text { Landfill } \\
\text { Operations }\end{array}$ & $\begin{array}{c}\text { Unsuitable } \\
\text { Area }\end{array}$ & $\begin{array}{l}\text { Total Area } \\
\text { Remaining }\end{array}$ \\
\hline I & 448.0 & 29.8 & 0.0 & 0.0 & 0.0 & 23.0 & 0.0 & 319.2 & 49.3 & 421.3 & 26.7 \\
\hline 2 & 36.0 & 0.0 & 0.0 & 0.0 & 0.0 & 0.0 & 0.0 & 22.3 & 1.5 & 23.8 & 12.2 \\
\hline 3 & 196.0 & 15.5 & 0.0 & 4.0 & 0.0 & 7.8 & 0.0 & 0.4 & 7.6 & 35.3 & 160.7 \\
\hline 4 & 35.0 & 0.0 & 0.0 & 0.0 & 0.0 & 5.9 & 0.0 & 23.7 & 0.0 & 29.6 & 5.4 \\
\hline 5 & 62.0 & 12.1 & 0.0 & 3.9 & 0.0 & 7.2 & 0.0 & 0.9 & 0.0 & 24.1 & 37.9 \\
\hline 6 & 97.0 & 1.1 & 0.0 & 0.0 & 0.0 & 4.9 & 0.0 & 1.3 & 39.7 & 47.0 & 50.0 \\
\hline 7 & 49.0 & 3.7 & 16 & 0.0 & 0.0 & 9.2 & 0.0 & 0.0 & 0.0 & 14.5 & 34.5 \\
\hline 8 & 83.0 & 36.4 & 0.0 & 0.0 & 0.0 & 13.9 & 0.0 & 0.0 & 0.0 & 50.3 & 32.7 \\
\hline 9 & 42.0 & 12.5 & 0.0 & 0.0 & 0.0 & 18.5 & 0.0 & 0.0 & 0.0 & 31.0 & 11.0 \\
\hline 10 & 9.5 & 0.0 & 0.0 & 0.0 & 0.0 & 3.2 & 0.0 & 0.0 & 0.0 & 3.2 & 6.3 \\
\hline Total & 1057.5 & 111.1 & 1.6 & 7.9 & 0.0 & 93.6 & 0.0 & 367.8 & 98.1 & 680.1 & 377.4 \\
\hline
\end{tabular}

\section{Sieve 2 Analysis}

The second level of screening was the result of two combinations of factors that combined to render an additional 149.9 acres of land unsuitable for development. Combinations are intended to respond to conditions as they occur on the site rather than a generic combination of factors that may, or may not, play a role in a land suitability analysis for a specific site. The first combination is the slope combined with surface boulders. The second combines 8-15 percent slope, forest, and soil with a high erosion hazard. As in the first sieve, areas of constraints are consecutively layered over one another to result in an addition to the area deemed unsuitable for development. The resultant land area not classified as unsuitable for development is a total of 227.3 acres which is twenty-one percent of the land at the Central Landfill. Table 5.2 and map 5.2 illustrate the area of land eliminated under the second level of screening.

Table 5.2 Sieve 2 Screening Results

\begin{tabular}{|c|c|c|c|c|c|}
\hline Zone & Area & $\begin{array}{c}\text { Combination } \\
\text { No. } 1\end{array}$ & $\begin{array}{c}\text { Combination } \\
\text { No. } 2\end{array}$ & $\begin{array}{c}\text { Unsuitable } \\
\text { Area }\end{array}$ & $\begin{array}{l}\text { Total Area } \\
\text { Remaining }\end{array}$ \\
\hline 1 & 26.7 & 17.8 & 0.0 & 17.8 & 8.9 \\
\hline 2 & 12.2 & 4.6 & 4.3 & 8.9 & 3.3 \\
\hline 3 & 160.7 & 5.7 & 48.4 & 54.1 & 106.6 \\
\hline 4 & 5.4 & 5.4 & 0.0 & 5.4 & 0.0 \\
\hline 5 & 37.9 & 1.6 & 0.0 & 1.6 & 36,3 \\
\hline 6 & 50.0 & 50.0 & 0.0 & 50.0 & 0.0 \\
\hline 7 & 34.5 & 8.8 & 0.0 & 8.8 & 25.7 \\
\hline 8 & 32.7 & 2.1 & 0.0 & 2.1 & 30.6 \\
\hline 9 & 11.0 & 0.2 & 0.0 & 0.2 & I0.8 \\
\hline 10 & 6.3 & 0.0 & 1.9 & 1.9 & 4.4 \\
\hline Total & 377.4 & 96.2 & 54.6 & 150.8 & 226.6 \\
\hline
\end{tabular}




\section{Preliminary Suitability Analysis}

This initial suitability analysis considers only that land not classified as unsuitable for development. In addition to eliminating unsuitable land from further analysis, factors used in previous analysis are eliminated from the process. Factors analyzed for the base land use suitability are: degree of slope; height and duration of the Seasonal High Water Table; rockiness of the soil ranging from small stones to surface boulders; and the vegetative cover which includes upland forest, red maple forest, transitional forest and upland field. As in the 1996 Land Use Study the constraint levels: slight; slight-moderate; moderate; moderate-severe; and, severe, are used to maintain consistency between the two studies. Table 5.3 contains a summary of preliminary constraint levels for modification through the last three screenings. Map 5.1 illustrates the results of the preliminary suitability analysis.

Table 5.3 Preliminary Suitability Analysis

\begin{tabular}{lrrrrrr}
\hline Zone & Slight & \multicolumn{1}{c}{$\begin{array}{c}\text { Slight - } \\
\text { Moderate }\end{array}$} & Moderate & $\begin{array}{c}\text { Moderate - } \\
\text { Severe }\end{array}$ & Severe & $\begin{array}{c}\text { Total } \\
\text { Area }\end{array}$ \\
\hline 1 & 0 & 1.5 & 0 & 7.4 & 0 & 8.9 \\
2 & 0.8 & 2.5 & 0 & 0 & 0 & 3.3 \\
3 & 10.5 & 79.6 & 10.8 & 5.7 & 0 & 106.6 \\
4 & 0 & 0 & 0 & 0 & 0 & 0.0 \\
5 & 5.3 & 31.0 & 0 & 0 & 0 & 36.3 \\
6 & 0 & 0 & 0 & 0 & 0 & 0.0 \\
7 & 0 & 0 & 17.3 & 8.4 & 0 & 25.7 \\
8 & 0 & 21.6 & 0 & 9.0 & 0 & 30.6 \\
9 & 0 & 0 & 0 & 10.8 & 0 & 10.8 \\
10 & 2.2 & 2.2 & 0 & 0 & 0 & 4.4 \\
\hline Total & 18.8 & 138.4 & 28.1 & 41.3 & 0 & 226.6 \\
\hline Note Area is in acres & & & & & 0
\end{tabular}

\section{Sieve 3 Analysis}

Beginning with the third sieve, the analysis shifts from eliminating parcels from consideration to modifying the preliminary suitability analysis. This screening modifies suitability levels based on the degree of physical isolation caused by the wetlands whether on one or two sides of a parcel, the distance of a parcel from roads, water and sewer lines, and the size of that parcel. Determining the degree of isolation due to wetlands relied on whether an area of land was completely surrounded by wetlands, along three sides, or along two sides of the analyzed land parcel. Land completely surrounded by wetlands rendered it unsuitable for development. The suitability of land with wetlands on two or three sides was impacted by the size of the parcel and intensity of use. The other factors used in determining suitability based on degree of accessibility are distance to roads, water and sewer lines. Again the impact each factor has on overall suitability depends on the size of a parcel, or blocks of parcels and the intensity of use analyzed. From an environmental perspective the degree of isolation due to wetlands is a major factor determining suitability due to the impacts related to issues such as runoff, and septic fields. 
The Industrial Park Feasibility Study completed by Crossman Engineering December of 1996 identifies the extent of all public services in the vicinity of the Central Landfill. With the potential threat to the quality of ground water from landfill leachate access to water lines plays a more important role in determining suitability for development than access to sewer services. The only sewer line in the vicinity of RIRRC property connects the Central Landfill sewer pump station along Greenhill Road to a trunk line running along Route 114 on the Johnston and Cranston border. The Feasibility Study points out the need for expansion of the areas sewer capacity for any industrial development to occur. The entire area around the Central Landfill is supported with water lines. Again, development suitability is related to the size of the area, its distance from roads and services and the intensity of development. Tables 5.4.a - $f$ contain summaries of land suitability for the land uses analyzed.

Table 5.4.a Sieve 3 Industrial Use Summary

\begin{tabular}{|c|c|c|c|c|c|c|c|c|}
\hline Zone & $\begin{array}{l}\text { Total } \\
\text { Area }\end{array}$ & $\begin{array}{c}\text { Not } \\
\text { Suitable }\end{array}$ & $\begin{array}{c}\text { Remaining } \\
\text { Area }\end{array}$ & Slight & $\begin{array}{c}\text { Slight - } \\
\text { Moderate }\end{array}$ & Moderate & $\begin{array}{l}\text { Moderate- } \\
\text { Severe }\end{array}$ & Severe \\
\hline 1 & 8.9 & 8.9 & 0.0 & 0.0 & 0.0 & 0.0 & 0.0 & 0.0 \\
\hline 2 & 3.3 & 3.3 & 0.0 & 0.0 & 0.0 & 0.0 & 0.0 & 0.0 \\
\hline 3 & 106.6 & 22.0 & 84.6 & 0.0 & 74.5 & 10.1 & 0.0 & 0.0 \\
\hline 4 & 0.0 & 0.0 & 0.0 & 0.0 & 0.0 & 0.0 & 0.0 & 0.0 \\
\hline 5 & 36.3 & 14.5 & 21.8 & 0.0 & 21.8 & 0.0 & 0.0 & 0.0 \\
\hline 6 & 0.0 & 0.0 & 0.0 & 0.0 & 0.0 & 0.0 & 0.0 & 0.0 \\
\hline 7 & 25.7 & 9.6 & 16.1 & 0.0 & 0.0 & 0.0 & 16.1 & 0.0 \\
\hline 8 & 30.6 & 14.0 & 16.6 & 0.0 & 0.0 & 0.0 & 16.6 & 0.0 \\
\hline 9 & 10.8 & 10.8 & 0.0 & 0.0 & 0.0 & 0.0 & 0.0 & 0.0 \\
\hline 10 & 4.4 & 4.4 & 0.0 & 0.0 & 0.0 & 0.0 & 0.0 & 0.0 \\
\hline Total & 226.6 & 87.5 & 139.1 & 0.0 & 96.3 & 10.1 & 32.7 & 0.0 \\
\hline
\end{tabular}

Table 5.4.b Sieve 3 Institutional Use Summary

\begin{tabular}{|c|c|c|c|c|c|c|c|c|}
\hline Zone & $\begin{array}{l}\text { Total } \\
\text { Area }\end{array}$ & $\begin{array}{c}\text { Not } \\
\text { Suitable }\end{array}$ & $\begin{array}{c}\text { Remaining } \\
\text { Area }\end{array}$ & Slight & $\begin{array}{c}\text { Slight - } \\
\text { Moderate }\end{array}$ & Moderate & $\begin{array}{c}\text { Moderate- } \\
\text { Severe }\end{array}$ & Severe \\
\hline 1 & 8.9 & 8.9 & 0.0 & 0.0 & 0.0 & 0.0 & 0.0 & 0.0 \\
\hline 2 & 3.3 & 3.3 & 0.0 & 0.0 & 0.0 & 0.0 & 0.0 & 0.0 \\
\hline 3 & 106.6 & 9.2 & 97.4 & 0.0 & 68.1 & 29.3 & 0.0 & 0.0 \\
\hline 4 & 0.0 & 0.0 & 0.0 & 0.0 & 0.0 & 0.0 & 0.0 & 0.0 \\
\hline 5 & 36.3 & 14.5 & 21.8 & 0.0 & 21.8 & 0.0 & 0.0 & 0.0 \\
\hline 6 & 0.0 & 0.0 & 0.0 & 0.0 & 0.0 & 0.0 & 0.0 & 0.0 \\
\hline 7 & 25.7 & 9.6 & 16.1 & 0.0 & 0.0 & 0.0 & 16.1 & 0.0 \\
\hline 8 & 30.6 & 14.0 & 16.6 & 0.0 & 0.0 & 0.0 & 16.6 & 0.0 \\
\hline 9 & 10.8 & 10.8 & 0.0 & 0.0 & 0.0 & 0.0 & 0.0 & 0.0 \\
\hline 10 & 4.4 & 4.4 & 0.0 & 0.0 & 0.0 & 0.0 & 0.0 & 0.0 \\
\hline Total & 226.6 & 74.7 & 151.9 & 0.0 & 89.9 & 29.3 & 32.7 & 0.0 \\
\hline
\end{tabular}


Table 5.4.c Sieve 3 Commercial Use Summary

\begin{tabular}{|c|c|c|c|c|c|c|c|c|}
\hline Zone & $\begin{array}{l}\text { Total } \\
\text { Area }\end{array}$ & $\begin{array}{c}\text { Not } \\
\text { Suitable }\end{array}$ & $\begin{array}{c}\text { Remaining } \\
\text { Area }\end{array}$ & Slight & $\begin{array}{c}\text { Slight - } \\
\text { Moderate }\end{array}$ & Moderate & $\begin{array}{c}\text { Moderate- } \\
\text { Severe }\end{array}$ & Severe \\
\hline 1 & 8.9 & 4.6 & 4.3 & 0.0 & 0.0 & 0.0 & 0.0 & 4.3 \\
\hline 2 & 3.3 & 0.0 & 3.3 & 0.0 & 0.0 & 2.9 & 0.0 & 0.4 \\
\hline 3 & 106.6 & 0.0 & 106.6 & 0.0 & 17.7 & 71.4 & 13.6 & 3.9 \\
\hline 4 & 0.0 & 0.0 & 0.0 & 0.0 & 0.0 & 0.0 & 0.0 & 0.0 \\
\hline 5 & 36.3 & 0.0 & 36.3 & 0.0 & 21.8 & 0.0 & 0.0 & 14.5 \\
\hline 6 & 0.0 & 0.0 & 0.0 & 0.0 & 0.0 & 0.0 & 0.0 & 0.0 \\
\hline 7 & 25.7 & 0.0 & 25.7 & 0.0 & 0.0 & 0.0 & 16.1 & 9.6 \\
\hline 8 & 30.6 & 2.8 & 27.8 & 0.0 & 0.0 & 0.0 & 16.6 & 11.2 \\
\hline 9 & 10.8 & 9.5 & 1.3 & 0.0 & 0.0 & 0.0 & 0.0 & 1.3 \\
\hline 10 & 4.4 & 0.0 & 4.4 & 0.0 & 0.0 & 4.4 & 0.0 & 0.0 \\
\hline Total & 226.6 & 16.9 & 209.7 & 0.0 & 39.5 & 78.7 & 46.3 & 45.2 \\
\hline
\end{tabular}

Table 5.4.d Sieve 3 Residential Use Summary - less than 5 Units per acre

\begin{tabular}{|c|c|c|c|c|c|c|c|c|}
\hline$\overline{\text { Zone }}$ & $\begin{array}{l}\text { Total } \\
\text { Area }\end{array}$ & $\begin{array}{c}\text { Not } \\
\text { Suitable }\end{array}$ & $\begin{array}{c}\text { Remaining } \\
\text { Area }\end{array}$ & Slight & $\begin{array}{c}\text { Slight - } \\
\text { Moderate }\end{array}$ & Moderate & $\begin{array}{l}\text { Moderate- } \\
\text { Severe }\end{array}$ & Severe \\
\hline 1 & 8.9 & 0.0 & 8.9 & 0.0 & 0.0 & 0.0 & 0.5 & 8.4 \\
\hline 2 & 3.3 & 0.0 & 3.3 & 0.0 & 2.2 & 1.1 & 0.0 & 0.0 \\
\hline 3 & 106.6 & 0.0 & 106.6 & 0.0 & 86.9 & 13.6 & 5.5 & 0.6 \\
\hline 4 & 0.0 & 0.0 & 0.0 & 0.0 & 0.0 & 0.0 & 0.0 & 0.0 \\
\hline 5 & 36.3 & 0.0 & 36.3 & 0.0 & 21.8 & 0.0 & 14.5 & 0.0 \\
\hline 6 & 0.0 & 0.0 & 0.0 & 0.0 & 0.0 & 0.0 & 0.0 & 0.0 \\
\hline 7 & 25.7 & 0.0 & 25.7 & 0.0 & 0.0 & 0.0 & 0.0 & 25.7 \\
\hline 8 & 30.6 & 2.8 & 27.8 & 0.0 & 0.0 & 0.0 & 0.0 & 27.8 \\
\hline 9 & 10.8 & 9.5 & 1.3 & 0.0 & 0.0 & 0.0 & 0.2 & 1.1 \\
\hline 10 & 4.4 & 0.0 & 4.4 & 0.0 & 4.4 & 0.0 & 0.0 & 0.0 \\
\hline Total & 226.6 & 12.3 & 214.3 & 0.0 & 115.3 & 14.7 & 20.7 & 63.6 \\
\hline
\end{tabular}

Table 5.4.e Sieve 3 Residential Use Summary - 5 to 10 Units per acre

\begin{tabular}{|c|c|c|c|c|c|c|c|c|}
\hline Zone & $\begin{array}{l}\text { Total } \\
\text { Area }\end{array}$ & $\begin{array}{c}\text { Not } \\
\text { Suitable }\end{array}$ & $\begin{array}{c}\text { Remaining } \\
\text { Area }\end{array}$ & Slight & $\begin{array}{l}\text { Slight - } \\
\text { Moderate }\end{array}$ & Moderate & $\begin{array}{c}\text { Moderate- } \\
\text { Severe }\end{array}$ & Severe \\
\hline$\overline{1}$ & 8.9 & 2.4 & 6.5 & 0.0 & 0.0 & 0.0 & 6.5 & 0.0 \\
\hline 2 & 3.3 & 1.1 & 2.2 & 0.0 & 0.0 & 2.2 & 0.0 & 0.0 \\
\hline 3 & 106.6 & 8.6 & 98.0 & 0.0 & 86.8 & 7.1 & 0.0 & 4.1 \\
\hline 4 & 0.0 & 0.0 & 0.0 & 0.0 & 0.0 & 0.0 & 0.0 & 0.0 \\
\hline 5 & 36.3 & 0.0 & 36.3 & 0.0 & 21.8 & 0.0 & 14.5 & 0.0 \\
\hline 6 & 0.0 & 0.0 & 0.0 & 0.0 & 0.0 & 0.0 & 0.0 & 0.0 \\
\hline 7 & 25.7 & 0.0 & 25.7 & 0.0 & 0.0 & 0.0 & 0.0 & 25.7 \\
\hline 8 & 30.6 & 5.7 & 24.9 & 0.0 & 0.0 & 0.0 & 0.0 & 24.9 \\
\hline 9 & 10.8 & 10.8 & 0.0 & 0.0 & 0.0 & 0.0 & 0.0 & 0.0 \\
\hline 10 & 4.4 & 0.0 & 4.4 & 0.0 & 0.0 & 4.4 & 0.0 & 0.0 \\
\hline Total & 226.6 & 28.6 & 198.0 & 0.0 & 108.6 & 13.7 & 21.0 & 54.7 \\
\hline
\end{tabular}


Table 5.4.f Sieve 3 Residential Use Summary - 10 Units or more per acre

\begin{tabular}{|c|c|c|c|c|c|c|c|c|}
\hline Zone & $\begin{array}{l}\text { Total } \\
\text { Area }\end{array}$ & $\begin{array}{c}\text { Not } \\
\text { Suitable }\end{array}$ & $\begin{array}{c}\text { Remaining } \\
\text { Area }\end{array}$ & Slight & $\begin{array}{c}\text { Slight - } \\
\text { Moderate }\end{array}$ & Moderate & $\begin{array}{c}\text { Moderate- } \\
\text { Severe }\end{array}$ & Severe \\
\hline 1 & 8.9 & 8.9 & 0.0 & 0.0 & 0.0 & 0.0 & 0.0 & 0.0 \\
\hline 2 & 3.3 & 3.3 & 0.0 & 0.0 & 0.0 & 0.0 & 0.0 & 0.0 \\
\hline 3 & 106.6 & 14.3 & 92.3 & 0.0 & 81.5 & 10.8 & 0.0 & 0.0 \\
\hline 4 & 0.0 & 0.0 & 0.0 & 0.0 & 0.0 & 0.0 & 0.0 & 0.0 \\
\hline 5 & 36.3 & 21.8 & 14.5 & 0.0 & 0.0 & 0.0 & 0.0 & 14.5 \\
\hline 6 & 0.0 & 0.0 & 0.0 & 0.0 & 0.0 & 0.0 & 0.0 & 0.0 \\
\hline 7 & 25.7 & 0.0 & 25.7 & 0.0 & 0.0 & 0.0 & 16.1 & 9.6 \\
\hline 8 & 30.6 & 5.7 & 24.9 & 0.0 & 0.0 & 0.0 & 16.6 & 8.3 \\
\hline 9 & 10.8 & 10.8 & 0.0 & 0.0 & 0.0 & 0.0 & 0.0 & 0.0 \\
\hline 10 & 4.4 & 4.4 & 0.0 & 0.0 & 0.0 & 0.0 & 0.0 & 0.0 \\
\hline Total & 226.6 & 69.2 & 157.4 & 0.0 & 81.5 & 10.8 & 32.7 & 32.4 \\
\hline
\end{tabular}

While there are variations within the data from the Sieve Three screening one pattern does stand out.

Regardless of the land uses analyzed, the constraint levels for each land use per each zone remains somewhat consistent throughout. An example that illustrates this consistency is in Zone Three. With the example of commercial use the bulk of the land is concentrated within "slight-moderate" and "moderate" constraints. Within commercial land use the largest portion of the land falls in the "moderate" constraint category, while for the other uses the bulk of the land analyzed falls within the "slight-moderate" constraint class. Another difference is that more acreage is spread across four classes of constraints than the other uses. This may indicate that at this stage in the analysis land use requirements are more similar than different. Even though differences are not extreme it does indicate that a series of written rules unique to a mix of different land uses and site conditions function to screen out land differently for each use.

\section{Sieve 4 Analysis}

The fourth level of analysis adjusts the developability of a parcel based on nearby land uses. The factors considered include: road access to the parcel, as in what land use does the road system pass through to get to the parcel; and what are the adjacent land uses. Adjacent land uses are based on what land use exists, planned and allowed by zoning. This part of the analysis is needed to consider the impacts of different intensity levels of development on established land uses. The importance of this part of the analysis is to screen for incompatible uses and incompatible use intensities. Tables 5.5. $\mathrm{a}-\mathrm{f}$ contain summaries of land suitability for the land uses analyzed. 
Table 5.5.a Sieve 4 Industrial Use Summary

\begin{tabular}{|c|c|c|c|c|c|c|c|c|}
\hline Zone & $\begin{array}{l}\text { Total } \\
\text { Area }\end{array}$ & $\begin{array}{c}\text { Not } \\
\text { Suitable }\end{array}$ & $\begin{array}{c}\text { Remaining } \\
\text { Area }\end{array}$ & Slight & $\begin{array}{c}\text { Slight - } \\
\text { Moderate }\end{array}$ & Moderate & $\begin{array}{c}\text { Moderate- } \\
\text { Severe }\end{array}$ & Severe \\
\hline 1 & 0.0 & 0.0 & 0.0 & 0.0 & 0.0 & 0.0 & 0.0 & 0.0 \\
\hline 2 & 0.0 & 0.0 & 0.0 & 0.0 & 0.0 & 0.0 & 0.0 & 0.0 \\
\hline 3 & 84.6 & 25.8 & 58.9 & 0.0 & 589 & 0.0 & 0.0 & 0.0 \\
\hline 4 & 0.0 & 0.0 & 0.0 & 0.0 & 0.0 & 0.0 & 0.0 & 0.0 \\
\hline 5 & 21.8 & 21.9 & 0.0 & 0.0 & 0.0 & 0.0 & 0.0 & 0.0 \\
\hline 6 & 0.0 & 0.0 & 0.0 & 0.0 & 0.0 & 0.0 & 0.0 & 0.0 \\
\hline 7 & 16.1 & 5.1 & 11.0 & 0.0 & 0.0 & 0.0 & 11.0 & 0.0 \\
\hline 8 & 16.6 & 0.0 & 16.6 & 0.0 & 0.0 & 0.0 & 16.6 & 0.0 \\
\hline 9 & 0.0 & 0.0 & 0.0 & 0.0 & 0.0 & 0.0 & 0.0 & 0.0 \\
\hline 10 & 0.0 & 0.0 & 0.0 & 0.0 & 0.0 & 0.0 & 0.0 & 0.0 \\
\hline$\overline{\text { Total }}$ & 139.1 & 52.6 & 86.5 & 0.0 & 58.9 & 0.0 & 27.6 & 0.0 \\
\hline
\end{tabular}

Table 5.5.b Sieve 4 Institutional Use Summary

\begin{tabular}{|c|c|c|c|c|c|c|c|c|}
\hline Zone & $\begin{array}{l}\text { Total } \\
\text { Area }\end{array}$ & $\begin{array}{c}\text { Not } \\
\text { Suitable }\end{array}$ & $\begin{array}{c}\text { Remaining } \\
\text { Area }\end{array}$ & Slight & $\begin{array}{l}\text { Slight - } \\
\text { Moderate }\end{array}$ & Moderate & $\begin{array}{c}\text { Moderate- } \\
\text { Severe }\end{array}$ & Severe \\
\hline 1 & 0.0 & 0.0 & 0.0 & 0.0 & 0.0 & 0.0 & 0.0 & 0.0 \\
\hline 2 & 0.0 & 0.0 & 0.0 & 0.0 & 0.0 & 0.0 & 0.0 & 0.0 \\
\hline 3 & 97.4 & 36.3 & 61.1 & 0.0 & 0.0 & 61.1 & 0.0 & 0.0 \\
\hline 4 & 0.0 & 0.0 & 0.0 & 0.0 & 0.0 & 0.0 & 0.0 & 0.0 \\
\hline 5 & 21.8 & 13.7 & 8.1 & 0.0 & 8.1 & 0.0 & 0.0 & 0.0 \\
\hline 6 & 0.0 & 0.0 & 0.0 & 0.0 & 0.0 & 0.0 & 0.0 & 0.0 \\
\hline 7 & 16.1 & 5.0 & 11.1 & 0.0 & 0.0 & 0.0 & 11.1 & 0.0 \\
\hline 8 & 16.6 & 0.0 & 16.6 & 0.0 & 0.0 & 0.0 & 16.6 & 0.0 \\
\hline 9 & 0.0 & 0.0 & 0.0 & 0.0 & 0.0 & 0.0 & 0.0 & 0.0 \\
\hline 10 & 0.0 & 0.0 & 0.0 & 0.0 & 0.0 & 0.0 & 0.0 & 0.0 \\
\hline Total & 151.9 & 55.0 & 96.9 & 0.0 & 8.1 & 61.1 & 27.7 & 0.0 \\
\hline
\end{tabular}

Table 5.5.c Sieve 4 Commercial Use Summary

\begin{tabular}{|c|c|c|c|c|c|c|c|c|}
\hline $\bar{Z}$ Zone & $\begin{array}{l}\text { Total } \\
\text { Area }\end{array}$ & $\begin{array}{c}\text { Not } \\
\text { Suitable }\end{array}$ & $\begin{array}{c}\text { Remaining } \\
\text { Area }\end{array}$ & Slight & $\begin{array}{c}\text { Slight - } \\
\text { Moderate }\end{array}$ & Moderate & $\begin{array}{l}\text { Moderate- } \\
\text { Severe }\end{array}$ & Severe \\
\hline 1 & 4.3 & 1.0 & 3.3 & 0.0 & 0.0 & 0.0 & 0.0 & 3.3 \\
\hline 2 & 3.3 & 0.4 & 2.9 & 0.0 & 0.0 & 2.9 & 0.0 & 0.0 \\
\hline 3 & 106.6 & 30.8 & 75.8 & 0.0 & 0.0 & 0.0 & 63.7 & 12.1 \\
\hline 4 & 0.0 & 0.0 & 0.0 & 0.0 & 0.0 & 0.0 & 0.0 & 0.0 \\
\hline 5 & 36.3 & 6.2 & 30.1 & 0.0 & 8.2 & 0.0 & 2.6 & 19.3 \\
\hline 6 & 0.0 & 0.0 & 0.0 & 0.0 & 0.0 & 0.0 & 0.0 & 0.0 \\
\hline 7 & 25.7 & 8.2 & 17.5 & 0.0 & 0.0 & 0.0 & 11.0 & 6.5 \\
\hline 8 & 27.8 & 5.0 & 22.8 & 0.0 & 0.0 & 0.0 & 16.6 & 6.2 \\
\hline 9 & 1.3 & 1.3 & 0.0 & 0.0 & 0.0 & 0.0 & 0.0 & 0.0 \\
\hline 10 & 4.4 & 0.0 & 4.4 & 0.0 & 0.0 & 0.0 & 0.0 & 4.4 \\
\hline Total & 209.7 & 52.9 & 156.8 & 0.0 & 8.2 & 2.9 & 93.9 & 53.0 \\
\hline
\end{tabular}


Table 5.5.d Sieve 4 Residential Use Summary - less than 5 Units per acre

\begin{tabular}{|c|c|c|c|c|c|c|c|c|}
\hline Zone & $\begin{array}{l}\text { Total } \\
\text { Area }\end{array}$ & $\begin{array}{c}\text { Not } \\
\text { Suitable }\end{array}$ & $\begin{array}{c}\text { Remaining } \\
\text { Area }\end{array}$ & Slight & $\begin{array}{l}\text { Slight - } \\
\text { Moderate }\end{array}$ & Moderate & $\begin{array}{c}\text { Moderate- } \\
\text { Severe }\end{array}$ & Severe \\
\hline$\overline{1}$ & 8.9 & 0.0 & 8.9 & 0.0 & 0.0 & 0.0 & 0.0 & 8.9 \\
\hline 2 & 3.3 & 0.0 & 3.3 & 0.0 & 2.9 & 0.4 & 0.0 & 0.0 \\
\hline 3 & 106.6 & 25.7 & 80.9 & 0.0 & 652 & 9.7 & 3.3 & 2.7 \\
\hline 4 & 0.0 & 0.0 & 0.0 & 0.0 & 0.0 & 0.0 & 0.0 & 0.0 \\
\hline 5 & 36.3 & 17.4 & 18.9 & 1.2 & 8.2 & 5.1 & 4.4 & 0.0 \\
\hline 6 & 0.0 & 0.0 & 0.0 & 0.0 & 0.0 & 0.0 & 0.0 & 0.0 \\
\hline 7 & 25.7 & 0.0 & 25.7 & 0.0 & 0.0 & 0.0 & 0.0 & 25.7 \\
\hline 8 & 27.8 & 5.0 & 22.8 & 0.0 & 0.0 & 0.0 & 0.0 & 22.8 \\
\hline 9 & 1.3 & 1.3 & 0.0 & 0.0 & 0.0 & 0.0 & 0.0 & 0.0 \\
\hline 10 & 4.4 & 0.0 & 4.4 & 0.0 & 0.0 & 0.0 & 0.0 & 4.4 \\
\hline Total & $2 ! 4.3$ & 49.4 & 164.9 & 1.2 & 76.3 & 15.2 & 7.7 & 64.5 \\
\hline
\end{tabular}

Table 5.5.e Sieve 4 Residential Use Summary - 5 to 10 Units per acre

\begin{tabular}{|c|c|c|c|c|c|c|c|c|}
\hline Zone & $\begin{array}{l}\text { Total } \\
\text { Area }\end{array}$ & $\begin{array}{c}\text { Not } \\
\text { Suitable }\end{array}$ & $\begin{array}{c}\text { Remaining } \\
\text { Area }\end{array}$ & Slight & $\begin{array}{l}\text { Slight - } \\
\text { Moderate }\end{array}$ & Moderate & $\begin{array}{c}\text { Moderate- } \\
\text { Severe }\end{array}$ & Severe \\
\hline 1 & 6.5 & 0.0 & 6.5 & 0.0 & 0.0 & 0.0 & 0.0 & 6.5 \\
\hline 2 & 2.2 & 0.0 & 2.2 & 0.0 & 2.2 & 0.0 & 0.0 & 0.0 \\
\hline 3 & 98.0 & 25.7 & 72.3 & 0.0 & 61.3 & 5.0 & 3.3 & 2.7 \\
\hline 4 & 0.0 & 0.0 & 0.0 & 0.0 & 0.0 & 0.0 & 0.0 & 0.0 \\
\hline 5 & 36.5 & 17.4 & 18.9 & 1.2 & 8.2 & 5.1 & 4.4 & 0.0 \\
\hline 6 & 0.0 & 0.0 & 0.0 & 0.0 & 0.0 & 0.0 & 0.0 & 0.0 \\
\hline 7 & 25.7 & 0.0 & 25.7 & 0.0 & 0.0 & 0.0 & 0.0 & 25.7 \\
\hline 8 & 24.9 & 5.0 & 19.9 & 0.0 & 0.0 & 0.0 & 0.0 & 19.9 \\
\hline 9 & 0.0 & 0.0 & 0.0 & 0.0 & 0.0 & 0.0 & 0.0 & 0.0 \\
\hline 10 & 4.4 & 0.0 & 4.4 & 0.0 & 0.0 & 0.0 & 0.0 & 4.4 \\
\hline Total & 198.0 & 48.1 & 149.9 & 1.2 & 71.7 & 10.1 & 7.7 & 59.2 \\
\hline
\end{tabular}

Table 5.5.f Sieve 4 Residential Use Summary - 10 Units or more per acre

\begin{tabular}{|c|c|c|c|c|c|c|c|c|}
\hline Zone & $\begin{array}{l}\text { Total } \\
\text { Area }\end{array}$ & $\begin{array}{c}\text { Not } \\
\text { Suitable }\end{array}$ & $\begin{array}{c}\text { Remaining } \\
\text { Area }\end{array}$ & Slight & $\begin{array}{l}\text { Slight - } \\
\text { Moderate }\end{array}$ & Moderate & $\begin{array}{c}\text { Moderate- } \\
\text { Severe }\end{array}$ & Severe \\
\hline 1 & 0.0 & 0.0 & 0.0 & 0.0 & 0.0 & 0.0 & 0.0 & 0.0 \\
\hline 2 & 0.0 & 0.0 & 0.0 & 0.0 & 0.0 & 0.0 & 0.0 & 0.0 \\
\hline 3 & 92.3 & 25.7 & 66.6 & 0.0 & 53.4 & 7.5 & 3.0 & 2.7 \\
\hline 4 & 0.0 & 0.0 & 0.0 & 0.0 & 0.0 & 0.0 & 0.0 & 0.0 \\
\hline 5 & 14.5 & 4.1 & 10.4 & 0.0 & 6.3 & 2.1 & 2.0 & 0.0 \\
\hline 6 & 0.0 & 0.0 & 0.0 & 0.0 & 0.0 & 0.0 & 0.0 & 0.0 \\
\hline 7 & 25.7 & 0.0 & 25.7 & 0.0 & 0.0 & 0.0 & 0.0 & 25.7 \\
\hline 8 & 24.9 & 5.0 & 19.9 & 0.0 & 0.0 & 0.0 & 0.0 & 19.9 \\
\hline 9 & 0.0 & 0.0 & 0.0 & 0.0 & 0.0 & 0.0 & 0.0 & 0.0 \\
\hline 10 & 0.0 & 0.0 & 0.0 & 0.0 & 0.0 & 0.0 & 0.0 & 0.0 \\
\hline Total & 157.4 & 34.8 & 122.6 & 0.0 & 59.7 & 9.6 & 5.0 & 48.3 \\
\hline
\end{tabular}


While the results of the analysis shows greater variation between the various land uses analyzed in Zone Three, there remains a certain consistency throughout. For example, in Zones Seven and Eight the constraint class and area remains constant for Industrial, Institutional and Commercial uses. While the area and class varies with the three intensities of residential use form the previous three there is a consistency within each. Within this level of screening the rules defining constraints due to access ways, and adjacent land uses become more specific, and restrictive to different uses.

\section{Sieve 5 Analysis}

The fifth and final sieve includes regulatory and statutory constraints. Of the final three screenings, the fifth sieve is the most restrictive. The remaining statutory restriction considered in this phase of the analysis is that imposed by the "Sections 23-19-34 and 35 of the R.I.G.L.," which forbid any use of land within 2000 feet of the Central Landfill purchased under those sections for other than industrial purposes. This final screening highlights the fact that land suitable for development other than industrial uses because of road access and adjacent uses is rendered unsuitable for any development as is the case in Study Zone Five. This includes small institutional uses, residential, and neighborhood scale commercial. A result of this large scale land purchase is that a significant amount of land was removed from the Town of Johnston Tax base. As currently stands due to restrictions on land use such as access through residential areas, adjacent residential uses developable land that cannot be used for industrial purposes cannot be returned to the Town of Johnston Tax base. Tables 5.6.a - $\mathrm{f}$ contain summaries of land suitability for the land uses analyzed in the Sieve Five screening process.

Table 5.6.a Sieve 5 Industrial Use Summary

\begin{tabular}{|c|c|c|c|c|c|c|c|c|}
\hline Zone & $\begin{array}{l}\text { Total } \\
\text { Area }\end{array}$ & $\begin{array}{c}\text { Not } \\
\text { Suitable }\end{array}$ & $\begin{array}{c}\text { Remaining } \\
\text { Area }\end{array}$ & Slight & $\begin{array}{c}\text { Slight - } \\
\text { Moderate }\end{array}$ & Moderate & $\begin{array}{l}\text { Moderate- } \\
\text { Severe }\end{array}$ & Severe \\
\hline 1 & 0.0 & 0.0 & 0.0 & 0.0 & 0.0 & 0.0 & 0.0 & $\overline{0.0}$ \\
\hline 2 & 0.0 & 0.0 & 0.0 & 0.0 & 0.0 & 0.0 & 0.0 & 0.0 \\
\hline 3 & 58.9 & 0.0 & 58.9 & 0.0 & 58.9 & 0.0 & 0.0 & 0.0 \\
\hline 4 & 0.0 & 0.0 & 0.0 & 0.0 & 0.0 & 0.0 & 0.0 & 0.0 \\
\hline 5 & 0.0 & 0.0 & 0.0 & 0.0 & 0.0 & 0.0 & 0.0 & 0.0 \\
\hline 6 & 0.0 & 0.0 & 0.0 & 0.0 & 0.0 & 0.0 & 0.0 & 0.0 \\
\hline 7 & 11.0 & 0.0 & 11.0 & 0.0 & 0.0 & 0.0 & 11.0 & 0.0 \\
\hline 8 & 16.6 & 0.0 & 16.6 & 0.0 & 0.0 & 0.0 & 16.6 & 0.0 \\
\hline 9 & 0.0 & 0.0 & 0.0 & 0.0 & 0.0 & 0.0 & 0.0 & 0.0 \\
\hline 10 & 0.0 & 0.0 & 0.0 & 0.0 & 0.0 & 0.0 & 0.0 & 0.0 \\
\hline Total & 86.5 & 0.0 & 86.5 & 0.0 & 58.9 & 0.0 & 27.6 & 0.0 \\
\hline
\end{tabular}


Table 5.6.b Sieve 5 Institutional Use Summary

\begin{tabular}{|c|c|c|c|c|c|c|c|c|}
\hline Zone & $\begin{array}{l}\text { Total } \\
\text { Area }\end{array}$ & $\begin{array}{c}\text { Not } \\
\text { Suitable }\end{array}$ & $\begin{array}{c}\text { Remaining } \\
\text { Area }\end{array}$ & Slight & $\begin{array}{c}\text { Slight - } \\
\text { Moderate }\end{array}$ & Moderate & $\begin{array}{l}\text { Moderate- } \\
\text { Severe }\end{array}$ & Severe \\
\hline 1 & 0.0 & 0.0 & 0.0 & 0.0 & 0.0 & 0.0 & 0.0 & 0.0 \\
\hline 2 & 0.0 & 0.0 & 0.0 & 0.0 & 0.0 & 0.0 & 0.0 & 0.0 \\
\hline 3 & 61.1 & 2.2 & 58.9 & 0.0 & 58.9 & 0.0 & 0.0 & 0.0 \\
\hline 4 & 0.0 & 0.0 & 0.0 & 0.0 & 0.0 & 0.0 & 0.0 & 0.0 \\
\hline 5 & 8.1 & 8.1 & 0.0 & 0.0 & 0.0 & 0.0 & 0.0 & 0.0 \\
\hline 6 & 0.0 & 0.0 & 0.0 & 0.0 & 0.0 & 0.0 & 0.0 & 0.0 \\
\hline 7 & 11.1 & 0.0 & 11.1 & 0.0 & 0.0 & 0.0 & 11.1 & 0.0 \\
\hline 8 & 16.6 & 0.0 & 16.6 & 0.0 & 0.0 & 0.0 & 16.6 & 0.0 \\
\hline 9 & 0.0 & 0.0 & 0.0 & 0.0 & 0.0 & 0.0 & 0.0 & 0.0 \\
\hline 10 & 0.0 & 0.0 & 0.0 & 0.0 & 0.0 & 0.0 & 0.0 & 0.0 \\
\hline Total & 96.9 & 10.3 & 86.6 & 0.0 & 58.9 & 0.0 & 27.7 & 0.0 \\
\hline
\end{tabular}

Table 5.6.c Sieve 5 Commercial Use Summary

\begin{tabular}{|c|c|c|c|c|c|c|c|c|}
\hline Zone & $\begin{array}{l}\text { Total } \\
\text { Area }\end{array}$ & $\begin{array}{c}\text { Not } \\
\text { Suitable }\end{array}$ & $\begin{array}{c}\text { Remaining } \\
\text { Area }\end{array}$ & Slight & $\begin{array}{l}\text { Slight - } \\
\text { Moderate }\end{array}$ & Moderate & $\begin{array}{l}\text { Moderate- } \\
\text { Severe }\end{array}$ & Severe \\
\hline 1 & 3.3 & 3.3 & 0.0 & 0.0 & 0.0 & 0.0 & 0.0 & 0.0 \\
\hline 2 & 2.9 & 2.9 & 0.0 & 0.0 & 0.0 & 0.0 & 0.0 & 0.0 \\
\hline 3 & 75.8 & 75.8 & 0.0 & 0.0 & 0.0 & 0.0 & 0.0 & 0.0 \\
\hline 4 & 0.0 & 0.0 & 0.0 & 0.0 & 0.0 & 0.0 & 0.0 & 0.0 \\
\hline 5 & 30.1 & 30.1 & 0.0 & 0.0 & 0.0 & 0.0 & 0.0 & 0.0 \\
\hline 6 & 0.0 & 0.0 & 0.0 & 0.0 & 0.0 & 0.0 & 0.0 & 0.0 \\
\hline 7 & 17.5 & 0.0 & 17.5 & 0.0 & 0.0 & 0.0 & 11.1 & 6.4 \\
\hline 8 & 22.8 & 0.0 & 22.8 & 0.0 & 0.0 & 0.0 & 16.6 & 6.2 \\
\hline 9 & 0.0 & 0.0 & 0.0 & 0.0 & 0.0 & 0.0 & 0.0 & 0.0 \\
\hline 10 & 4.4 & 4.4 & 0.0 & 0.0 & 0.0 & 0.0 & 0.0 & 0.0 \\
\hline Total & 156.8 & 116.5 & 40.3 & 0.0 & 0.0 & 0.0 & 27.7 & 12.6 \\
\hline
\end{tabular}

Table 5.6.d Sieve 5 Residential Use Summary - less than 5 Units per acre

\begin{tabular}{|c|c|c|c|c|c|c|c|c|}
\hline Zone & $\begin{array}{l}\text { Total } \\
\text { Area }\end{array}$ & $\begin{array}{c}\text { Not } \\
\text { Suitable }\end{array}$ & $\begin{array}{c}\text { Remaining } \\
\text { Area }\end{array}$ & Slight & $\begin{array}{c}\text { Slight - } \\
\text { Moderate }\end{array}$ & Moderate & $\begin{array}{c}\text { Moderate- } \\
\text { Severe }\end{array}$ & Severe \\
\hline I & 8.9 & 8.9 & 0.0 & 0.0 & 0.0 & 0.0 & 0.0 & 0.0 \\
\hline 2 & 3.3 & 3.3 & 0.0 & 0.0 & 0.0 & 0.0 & 0.0 & 0.0 \\
\hline 3 & 80.9 & 80.9 & 0.0 & 0.0 & 0.0 & 0.0 & 0.0 & 0.0 \\
\hline 4 & 0.0 & 0.0 & 0.0 & 0.0 & 0.0 & 0.0 & 0.0 & 0.0 \\
\hline 5 & 18.9 & 18.9 & 0.0 & 0.0 & 0.0 & 0.0 & 0.0 & 0.0 \\
\hline 6 & 0.0 & 0.0 & 0.0 & 0.0 & 0.0 & 0.0 & 0.0 & 0.0 \\
\hline 7 & 25.7 & 8.2 & 17.5 & 0.0 & 0.0 & 0.0 & 0.0 & 17.5 \\
\hline 8 & 22.8 & 11.2 & 11.6 & 0.0 & 0.0 & 0.0 & 0.0 & 11.6 \\
\hline 9 & 0.0 & 0.0 & 0.0 & 0.0 & 0.0 & 0.0 & 0.0 & 0.0 \\
\hline 10 & 4.4 & 4.4 & 0.0 & 0.0 & 0.0 & 0.0 & 0.0 & 0.0 \\
\hline Total & 164.9 & 135.8 & 29.1 & 0.0 & 0.0 & 0.0 & 0.0 & 29.1 \\
\hline
\end{tabular}


Table 5.6.e Sieve 5 Residential Use Summary - 5 to 10 Units per acre

\begin{tabular}{|c|c|c|c|c|c|c|c|c|}
\hline Zone & $\begin{array}{l}\text { Total } \\
\text { Area }\end{array}$ & $\begin{array}{c}\text { Not } \\
\text { Suitable }\end{array}$ & $\begin{array}{c}\text { Remaining } \\
\text { Area }\end{array}$ & Slight & $\begin{array}{l}\text { Slight - } \\
\text { Moderate }\end{array}$ & Moderate & $\begin{array}{l}\text { Moderate- } \\
\text { Severe }\end{array}$ & Severe \\
\hline 1 & 6.5 & 6.5 & 0.0 & 0.0 & 0.0 & 0.0 & 0.0 & 0.0 \\
\hline 2 & 2.2 & 2.2 & 0.0 & 0.0 & 0.0 & 0.0 & 0.0 & 0.0 \\
\hline 3 & 72.3 & 72.3 & 0.0 & 0.0 & 0.0 & 0.0 & 0.0 & 0.0 \\
\hline 4 & 0.0 & 0.0 & 0.0 & 0.0 & 0.0 & 0.0 & 0.0 & 0.0 \\
\hline 5 & 18.9 & 18.9 & 0.0 & 0.0 & 0.0 & 0.0 & 0.0 & 0.0 \\
\hline 6 & 0.0 & 0.0 & 0.0 & 0.0 & 0.0 & 0.0 & 0.0 & 0.0 \\
\hline 7 & 25.7 & 8.2 & 17.5 & 0.0 & 0.0 & 0.0 & 0.0 & 17.5 \\
\hline 8 & 19.9 & 11.2 & 8.7 & 0.0 & 0.0 & 0.0 & 0.0 & 8.7 \\
\hline 9 & 0.0 & 0.0 & 0.0 & 0.0 & 0.0 & 0.0 & 0.0 & 0.0 \\
\hline 10 & 4.4 & 4.4 & 0.0 & 0.0 & 0.0 & 0.0 & 0.0 & 0.0 \\
\hline Total & 149.9 & 123.7 & 26.2 & 0.0 & 0.0 & 0.0 & 0.0 & 26.2 \\
\hline
\end{tabular}

Table 5.6.f Sieve 5 Residential Use Summary - 10 Units or more per acre

\begin{tabular}{l|r|r|r|r|r|r|r|r}
\hline Zone & \multicolumn{1}{c|}{$\begin{array}{c}\text { Total } \\
\text { trea }\end{array}$} & $\begin{array}{c}\text { Not } \\
\text { Suitable }\end{array}$ & $\begin{array}{c}\text { Remaining } \\
\text { Area }\end{array}$ & \multicolumn{1}{c|}{$\begin{array}{c}\text { Slight } \\
\text { Moderate }\end{array}$} & $\begin{array}{c}\text { Moderate- } \\
\text { Severe }\end{array}$ & Severe \\
\hline $\mathbf{1}$ & 0.0 & 0.0 & 0.0 & 0.0 & 0.0 & 0.0 & 0.0 & 0.0 \\
$\mathbf{3}$ & 0.0 & 0.0 & 0.0 & 0.0 & 0.0 & 0.0 & 0.0 & 0.0 \\
$\mathbf{4}$ & 66.6 & 66.6 & 0.0 & 0.0 & 0.0 & 0.0 & 0.0 & 0.0 \\
$\mathbf{5}$ & 0.0 & 0.0 & 0.0 & 0.0 & 0.0 & 0.0 & 0.0 & 0.0 \\
$\mathbf{6}$ & 10.4 & 10.4 & 0.0 & 0.0 & 0.0 & 0.0 & 0.0 & 0.0 \\
$\mathbf{7}$ & 0.0 & 0.0 & 0.0 & 0.0 & 0.0 & 0.0 & 0.0 & 0.0 \\
$\mathbf{8}$ & 25.7 & 8.2 & 17.5 & 0.0 & 0.0 & 0.0 & 0.0 & 17.5 \\
$\mathbf{9}$ & 19.9 & 11.2 & 8.7 & 0.0 & 0.0 & 0.0 & 0.0 & 8.7 \\
$\mathbf{1 0}$ & 0.0 & 0.0 & 0.0 & 0.0 & 0.0 & 0.0 & 0.0 & 0.0 \\
\hline Total & 0.0 & 0.0 & 0.0 & 0.0 & 0.0 & 0.0 & 0.0 & 0.0 \\
\hline
\end{tabular}

\section{Summary}

A pattern regarding the relative degree of restriction within each level of screening begins to emerge. The first two sieves effectively eliminate land unsuitable for all potential land uses based on physical constraints, while the last three sieves become more restrictive with each level. Even though the final three screenings in turn become more restrictive to potential land uses, they are in turn become more easily altered. In Sieve Three the constraint level is not restrictive to specific uses as Sieves Four and Five. For example, the constraints are reduced with increase in the provision of roads and public services. Such investment may result in increases in property values which makes development of certain parcels more desirable. Within Sieve Four, constraints to specific types of development may be altered by changes within the zoning ordinance, and long-term land development patterns. The suitability impacts related to Sieve Five while the most use specific and restrictive, they are perhaps the most easily altered. Changes would require another legislative act to allow other land uses that in a broader context may be more suitable to the parcels in question 


\section{Chapter Six Conclusions}

Following a suitability analysis, it is necessary to provide a range of potential uses that parcels are capable of supporting. This chapter discusses land use options related to the existing physical, infrastructure and legal constraints at the Rhode Island Central Landfill. The analysis focused on existing conditions as the only scenario. An analysis more concerned with public policy than assessing the suitability of a land use analysis system exceeds the scope of this project. Such an analysis would focus on necessary statutory changes to allow uses that are currently forbidden under Sections 23-18.9-9.1 (b)(9): 23-19-24.35 of R.I.G.L. In addition to the analysis of public policy, a study of post landfill use would also require the analysis of economic and demographic trends in Johnston, Rhode Island and the State itself.

\section{Land Use Recommendations}

The following section discusses land use recommendations by zone. In addition to land uses discussed in the analysis, the category of open space conservation land is included. The following recommendations include ideal uses based on the physical analysis, what uses are not allowed due to accessibility and access, and statutory impediments including state legislation and local zoning.

Zone 1

- Continue to use Licensed Landfill Area for the Central Landfill Operations.

- Continue implementation of plans and the permitting process necessary to expand landfill operations into Phase IV and V landfill areas.

- Continue planning and initiation of Cedar Swamp Brook relocation and wetlands mitigation projects in the west and south portions of Zone 1 .

- Continue planning, permitting and expansion of gravel extraction operations in Southwest corner of zone to provide construction materials for the development of Phases IV and V.

- Study feasibility of expanding recycling facilities and materials handled such as organic materials including yard waste and storm damage debris, north of the Materials Recycling Facility within the Statutory Operations Area.

- Study potential of increasing landfill gas-to-energy production via current plant or alternative technologies as the landfill expands.

- Study the feasibility of using electricity generated from gas-to-energy production to any future developments occurring on Central Landfill property such as the proposed Industrial Park in Zone Three.

- Develop landscape and habitat management plan to manage areas seeded in upland field plant species and wetlands as wildlife habitat through restoration and reclamation efforts. 
Zone 2

- Maintain materials staging areas within Zone 2, using appropriate mitigation measures while needed for Central Landfill operations.

- Do not expand landfill operations eastward into Zone 2.

- Use Zone 2 as a physical and visual buffer between the licensed landfill and developments proposed for Zone 3 .

- Develop landscape and habitat management plan to manage areas seeded in upland field plant species as wildlife habitat through restoration and reclamation efforts.

Zone 3

- Pursue development of Zone 3 as Industrial/Research Park.

- Study feasibility of focusing on relationship to recycling products and technologies.

- Identify sources of public and private funding to advance such a direction if deemed feasible.

- Study feasibility of linkage with area universities and research institutes with a stake in recycling technologies.

- For parcels north of Central Pike explore options for transferring ownership to the Town of Johnston or organizations with an interest in providing recreation lands, or resource protection.

- For parcels north of Central Pike approach State and Town for statutory and zoning changes to allow use along road frontage as neighborhood scale business.

- For parcels north of Central Pike study feasibility for donating land for creating affordable home ownership opportunities and receiving necessary statutory and zoning changes to make it viable.

Zone 4

- Maintain Zone 4 as a physical and visual buffer between the residential area along Central Pike and the Central Landfill.

- Study feasibility of development for low intensity town use such as a communications tower.

- Develop landscape and habitat management plan to manage as wildlife habitat.

Zone 5

- Develop landscape and habitat management plan to manage north and western areas as wildlife habitat and wetlands buffer.

- Study feasibility for donating land for creating affordable home ownership opportunities and receiving necessary statutory and zoning changes to make it viable.

- Along Ariana Drive:

- Reclaim for management as wildlife habitat.

- Work with State and Town to change statutes and zoning to allow for small institutional uses. 
- Southeast corner:

- Work with State and Town to change statutes and zoning to allow for small institutional and professional uses.

Zone 6

- Establish and manage as wildlife habitat and wetlands buffer in the eastern and southwestern portions of Zone 6.

- Maintain central portion as materials staging area while necessary.

- Consider potential future uses and work with State and Town to make statutory and zoning to allow tax generating uses.

- Study feasibility of various use options including: small mixed use/neighborhood business: small institutional/office: town facilities: affordable housing.

- Reclamation and management as upland wildlife habitat.

- Along Central Pike

- Establish and manage as wildlife habitat in wetland areas.

- Work with State and Town to change statutes and zoning to allow for neighborhood businesses or affordable home ownership opportunities

\section{Zones 7}

- Transfer ownership of extreme western portion that lies within the Scituate Reservoir Watershed for watershed protection.

- Transfer entire zone to federal, state, local or private non-profit organization for wildlife management and wetlands protection.

Zones 8 and 9

- Transfer entire zone to federal, state, local or private non-profit organization for wildlife management and wetlands protection.

Zone 10

- Transfer ownership of Zone 10 for protection of Upper Simmons Reservoir water quality, wildlife habitat restoration or parkland.

\section{Project Summary}

This project explored an option to a system of land use suitability analysis that was suitable for large single owner properties. As observed in the review of literature the bulk of published material reviewed focuses 
on land use at a multi owner community or regional scale. Are those methods appropriate for determining specific land use suitability for parcels or is their focus on policy overly broad?

I believe that certain elements from these methods are suitable. The difficulty is determining what elements are suitable, and when they are suitable. While GIS allows a great degree of adaptability for land use analysis, the data and input intensive nature provides a threat of relying to greatly on the technology and obscures the necessity of a planners feel based on direct knowledge of a site. Further refining on techniques to develop analysis based on mathematical based systems and verbal rules of combination are necessary. This will happen with greater opportunities for applying such a system to a range of real world sites. These sites should include smaller single owner holdings up to multiple owner holdings on a regional scale.

Further studies should include multiple cases of various sizes, land characteristics, ownership and regulatory characteristics. Case studies should include the use of different methods of analysis including strict ordinal analysis and verbal rules of combination on the same parcel. By comparing the results of different methods of analysis on a range of conditions a relative level of desirability and accuracy may be determined as most suitable for varying conditions. Depending on the goals of suitability analysis these methods may be used more efficiently and effectively in deriving outcomes and in using monetary and personnel resources. Not all the world requires and desires what are presently primarily academic and bureaucratic in nature. One size does not fit all. 


\section{References}

1. Cowardin, Lewis M., Virginia Carter, Francis C. Golet. December 1979. Classification of Wetland and Deepwater Habitats of the United States. U.S. Fish and Wildlife service. Washington D.C.

2. Dowall, David E. 1990. The Public Real Estate Development Process. Journal of the American Planning Association.

3. Forman, Richard T. 1997. Land Mosaics: The Ecology of Landscapes and Regions. Cambridge University Press. Cambridge.

4. Hopkins, Lewis D. October 1977. Methods for Generating Land Suitability: A Comparative Evaluation. Journal of the American Institute of Planners. Vol. 43, No. 4.

5. Kaiser, Edward J., David R. Godschalk, and F. Stuart Chapin, Jr. 1995. $4^{\text {th }}$ Edition, Urban Land Use Planning. University of Illinois Press: Urbana and Chicago.

6. Marsh, William M. 1993. $2^{\text {nd }}$ Edition, Landscape Planning: Environmental Applications. Wiley: New York.

7. McHarg, Ian L. 1967. Design with Nature Wiley. New York

8. Quattromani, Thomas L. 1993. Masters Thesis Research Project: Industrial Site Survev, Westerly, Rhode Island. University of Rhode Island.

9. Tiner, Ralph W. September, 1989. Rhode Island Wetlands inventory. . U.S. Fish and Wildlife service. Newton Corner, Massachusetts.

10. Central Landfill Ecological Characterization Operable unit 2 Remedial Investigation - Task 2, Johnston, Rhode Island. GZA GeoEnvironmental, Inc. 1994.

11. Comprehensive Reuse Plan Davisville Naval Construction Battalion Center. 1994. Maguire Group, Providence, Rhode Island.

12. DAHM-SW03-92, Section 15.12. Rules and regulations for Solid Waste management facilities

13. Final Feasibility Study: Operable Unit OUI Central Landfill Volume I. GZA GeoEnvironmental, Inc. 1993.

14. Johnston Comprehensive plan, Draft sections on capital improvements and land use. 
15. Johnston, Rhode lsland Zoning Ordinance: Ordinance \# 94l, as amended December 14, 1997.

16. Rhode Island Comprehensive Solid waste Management Plan, as amended July 1996.

17. Rhode Island General Law sections , 23-18.9-9.1 (b)(9); 23-19-34, 35

18. Soils Survey: of Rhode Island. United States Soil Conservation Service. 1977. 